\title{
Investigation of Failures of White-Coat Plaster
}

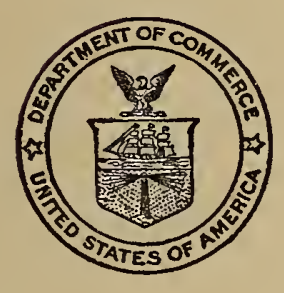

\section{United States Department of Commerce}

National Bureau of Standards

Building Materials and Structures Report 121 


\section{BUILDING MATERIALS AND STRUCTURES REPORTS}

On request, the Superintendent of Documents, U. S. Government Printing Office, Washington 25, D. C., will place your name on a special mailing list to receive notices of new reports in this series as soon as they are issued. There will be no charge for receiving such notices.

An alternative method is to deposit with the Superintendent of Documents the sum of $\$ 5$, with the request that the reports be sent to you as soon as issued, and that the cost thereof be charged against your deposit. This will provide for the mailing of the publications without delay. You will be notified when the amount of your deposit has become exhausted.

If 100 copies or more of any report are ordered at one time, a discount of 25 percent is allowed. Send all orders and remittances to the Superintendent of Documents, U. S. Government Printing Office, Washington 25, D. C.

The following publications in this series are available by purchase from the Superintendent of Documents at the prices indicated:

BMS1 Research on Building Materials and Structures for Use in Low-Cost Housing . BMS2 Methods of Determining the Structural Properties of Low-Cost House Constructions.- $10 \$$

BMS3 Suitability of Fiber Insulating Lath as a Plaster Base

BMS4 Accelerated Aging of Fiber Building Boards

BMS5 Structural Properties of Six Masonry Wall Constructions

BMS6 Survey of Roofing Materials in the Southeastern States.

BMS7 Water Permeability of Masonry Walls

BMS8 Methods of Investigation of Surface Treatment for Corrosion Protection of Steel...- 15\&

BMS9 Structural Properties of the Insulated Steel Construction Co.'s "Frameless-Steel" Constructions for Walls, Partitions, Floors, and Roofs

BMS10 Structural Properties of One of the "Keystone Beam Steel Floor" Constructions Sponsored by the H. H. Robertson Co

BMS11 Structural Properties of the Curren Fabrihome Corporation's "Fabrihome" Constructions for Walls and Partitions

BMS12 Structural Properties of "Steelox" Constructions for Walls, Partitions, Floors, and

BMS13 Properties of Some Fiber Building Boards of Current Manufacture

BMS14 Indentation and Recovery of Low-Cost Floor Coverings

BMS15 Structural Properties of "Wheeling Long-Span Steel Floor" Construction Sponsored

BMS16 Structural Properties of a "Tilecrete" Floor Construction Sponsored by Tilecrete Floors, Inc

BMS17 Sound Insulation of Wall and Floor Constructions

Supplement to BMS17, Sound Insulation of Wall and Floor Constructions

Supplement No. 2 to BMS17, Sound Insulation of Wall and Floor Constructions

BMS18 Structural Properties of "Pre-fab" Constructions for Walls, Partitions, and Floors Sponsored by the Harnischfeger Corporation... $10 \%$

BMS19 Preparation and Revision of Building Codes

BMS20 Structural Properties of "Twachtman" Constructions for Walls and Floors Sponsored by Connecticut Pre-Cast Buildings Corporation

BMS21 Structural Properties of a Concrete-Block Cavity-Wall Construction Sponsored by the

National Concrete Masonry Association
BMS22 Structural Properties of "Dun-Ti-Stone" Wall Construction Sponsored by the W. E.

BMS23 Structural Properties of a Bick Cavity-Wall Construction Sponsored by the Brick

Manufacturers Association of New York, Inc-
BMS24 Structural Properties of a Reinforced-Brick Wall Construction and a Brick-Tile Cavity-Wall Construction Sponsored by the Structural Clay Products Institute_- $15 \phi$

BMS25 Structural Properties of Conventional Wood-Frame Constructions for Walls, Parti-

tions, Floors, and Roofs Sponsored by the Nelson Cement Stone Co., Inc. Wall Construction Sponsored by the

BMS27 Structural Properties of "Bender Steel Home" Wall Construction Sponsored by the

BMS28 Backflow Prevention in Over-Rim Water Supplies

BMS29 Survey of Roofing Materials in the Northeastern States...

BMS30 Structural Properties of a Wood-Frame Wall Construction Sponsored by the Douglas Fir Plywood Association.

BMS31 Structural Properties of "Insulite" Wall and "Insulite" Partition Constructions

Out of print. Sponsored by The Insulite Co_. Wh

†Superseded by BMS116. 


\section{Investigation of Failures of White-Coat Plaster}

Lansing S. Wells, Walter F. Clarke, Edwin S. Newman, and Dana L. Bishop

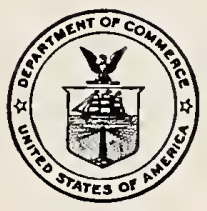

Building Materials and Structures Report 121

Issued February 1, 1951 


\section{Foreword}

The cost to the Nation of continual repairs of plastered surfaces is difficult to appraise, but it runs into millions of dollars annually. The cost to the Government of plaster repairs to only four buildings, for example, has been over $\$ 158,000$. The chief cause of these plaster failures has been a recurrent type that appears as a bulge, or blister, in the white coat of plaster, which may or may not affect the underlying base coat. This report presents the results of tests made on material taken from a large number of plaster failures of the blister type, scattered over the eastern United States. Detailed discussion is given of the preparation and properties of white-coat plaster and of the investigation leading to the conclusion that delayed hydration and expansion of the magnesia in the hydrated dolomitic lime used is responsible for the blister type of failure. The Bureau has cooperated in developing methods for the preparation of white-coat plaster that is not subject to these changes, and these methods have been introduced into actual production.

E. U. Condon, Director. 


\section{Contents}

Foreword _.

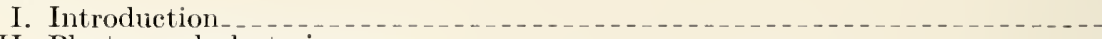

II. Plaster and plastering

1. Definition of plaster $\ldots \ldots \ldots \ldots$

2. Definition of plastering $\ldots \ldots \ldots \ldots \ldots$

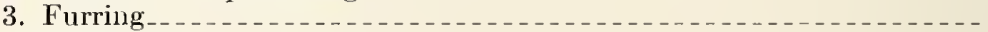

4. Base coat $\ldots \ldots \ldots \ldots \ldots \ldots$

5. Finish coat

III. Description of failures
1. Principal characteristics $\ldots \ldots$

2. Building components and plastering

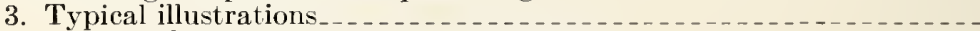

(a) On concrete beams and pilasters

(b) On ceilings $\ldots \ldots \ldots$

(c) On side walls

IV. Discussion of the formation and subsequent history of white-coat plaster

1. Materials used in preparing the white coat

(a) Quicklime $\ldots \ldots \ldots$

(b) Hydrated lime

(c) Gypsum gaging plaster

2. Preparation of the lime putty $\ldots \ldots$

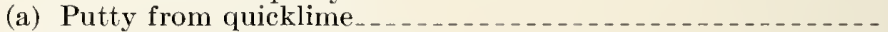

(b) Putty from hydrated lime

3. Application of the white coat

4. Chemical constituents of freshly set white-coat plaster

5. Drying and carbonation of the white coat

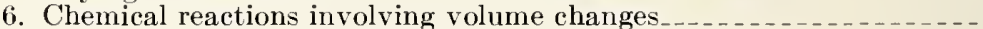

V. Investigation of white-coat-plaster samples taken after failure

1. Chemical analyses _.

2. Computed compound composition

3. Differential thermal analyses

4. Extent of hydration of magnesia in the aged white coat

5. X-ray analyses

6. Heat of solution $\ldots \ldots \ldots \ldots$

7. Composition of lime used in preparing the white coat

8. Ratio of lime putty to gaging plaster

9. Extent of carbonation of the lime

10. Expansion in autoclave.

VI. Investigation of some base coats $\ldots \ldots \ldots$

VII. Possible causes of failure of white-coat plaster other than hydration of magnesia.

1. Shrinkage of concrete

2. Differences in thermal expansion

3. Poor workmanship.

4. Improper carbonation

5. Improper gaging _...

6. Painting plaster before it is sufficiently dry

7. Paint shrinkage $\ldots \ldots \ldots \ldots$

8. Vibration $\ldots$

9. Movements in the structural frame.

VIII. Preventing failures of white-coat plaster in new buildings

IX. Methods of repairing damaged plaster

$\mathrm{X}$. Summary and conclusions

XI. References 


\title{
Investigation of Failures of White-Coat Plaster
}

\author{
Lansing S. Wells, Walter F. Clarke, Edwin S. Newman, and Dana L. Bishop
}

An investigation was made of a particular kind of plaster failure that is characterized by the formation of blisters or bulges in the finish coat of plaster. Extensive surveys revealed that the failures are widespread; that several years elapse before the bulges appear and thereafter the number and extent of failures increase as the age of the buildings increases; that the failures occur more extensively and rapidly during warm humid weather; and that there is a marked similarity in the failures regardless of the kind of plaster base coats, type of construction base, varying job conditions, and type of workmanship. The usual white coat is prepared from a lime putty gaged with plaster of paris (gypsum gaging plaster). Chemical analysis of 88 samples of white-coat plaster that had failed showed that in every instance a dolomitic lime had been used in preparing the white coat. Regularly hydrated dolomitic limes contain about 32 percent of total MgO (by weight), of which only about 5 percent is hydrated and the remaining 27 percent is still present as unhydrated MgO. This highly incomplete hydration is due to the fact that the magnesia has been badly overburned in the production of dolomitic quicklimes (which contain $\mathrm{CaO}$ and $\mathrm{MgO}$ in nearly equal molecular proportions) and thus is inactive toward hydration in the usual hydrators. Furthermore, only about 20 percent of the hydration of the magnesia is completed at the end of the customary 1-day soaking period. The amounts of $\mathrm{CaSO}_{4} \cdot 2 \mathrm{H}_{2} \mathrm{O}, \mathrm{CaCO}_{3}, \mathrm{Ca}(\mathrm{OH})_{2}, \mathrm{Mg}(\mathrm{OH})_{2}$, and $\mathrm{MgO}$ in the hardened plasters were calculated from the chemical analysis and closely checked by the method of heat of solution. The presence of $\mathrm{CaSO}_{4} \cdot 2 \mathrm{H}_{2} \mathrm{O}, \mathrm{Mg}(\mathrm{OH})_{2}, \mathrm{Ca}(\mathrm{OH})_{2}$, and $\mathrm{CaCO}_{3}$ was confirmed by thermal analysis. The average amount of hydration of the $\mathrm{MgO}$ for 88 samples of failed white coat was 59.0 percent-much in excess of the 20 percent attained after the customary 1 day of soaking the lime as a putty. Hydration of magnesia must, therefore, occur on the wall. The hydration of $\mathrm{MgO}$ is attended by marked expansion. Failures were also observed in base coats where dolomitic lime containing considerable unhydrated $\mathrm{MgO}$ was used in their preparation. It was shown that suggested causes other than hydration of $\mathrm{MgO}$ with its attendant expansion cannot account for the bulges that occur in plaster several years after a building has been erected. The precautions that should be exercised in specifying a proper lime in order to prevent future failures are discussed.

\section{Introduction}

Because it describes so clearly the type of plaster failure that is the subject of this investigation, the following excerpt is quoted from a letter written by the manager of a building to "Building and Management", a magazine published principally for building owners and managers.

The Provident Building, of which I am manager, has had trouble with falling plaster for the past ten years and I really expect it to continue until the building has been entirely replastered. The building was completed in 1924 and it was not until three or four years later that plaster trouble began to develop, but it has gradually increased until the condition has become really serious for the past several years.

The plaster in this building has been applied directly to concrete beams, to combination tile and concrete ceilings, and to hollow tile which forms the partitions. We have had no trouble at all with the brown coat of plaster but altogether with the white or skim coat of plaster. It manifests itself first in a slight bulge or blister which gradually increases until it breaks away from the brown coat and falls off the wall; the size of the places varies from a silver dollar to two or three square feet and in some instances whole shects of white coat fall from ceilings . . .
In conclusion I would refer you to Research Paper RP 1022, U. S. Department of Commerce, National Bureau of Standards, which has just come to my attention and which may have some bearing on the question . . [1] 1

Numerous letters from widely scattered localities have been received at the National Bureau of Standards, describing similar plaster failures on various backings and seeking advice either as to their cause, or remedy, or both.

Publication of National Bureau of Standards Research Paper RP1022, "Hydration of Magnesia in Dolimitic Hydrated Limes and Putties" [2], referred to in the letter to "Building and Building Management", soon led to consideration of the actual effect (if any) of unhydrated magnesia $(\mathrm{MgO})$ in partially hydrated dolomitic limes on the performance of mortars and plasters containing such limes, and the National Bureau of Standards soon became interested in this problem as it relates to plaster. ${ }^{2}$

\footnotetext{
1 Figures in brackets indicate the literature references at the end of this paper.

2 The contention that the presence of unhydrated $\mathrm{MgO}$ in the wbite coat might be responsible for failure because of the expansion attending its delayed hydration is by no means as receut as $193-$ with the publication of RP1022 hydration is by no ineans as recent as 1937 with the publican of RP1022 In $1922 \mathrm{~J}$. W. MeBurney aseribed the plaster failures at MIt. Sinai Hospital, magnesia in the lime used in preparing the plaster.
mation of tbe
} 
It was decided to undertake surveys of plaster in buildings to determine the prevalence of failures and to seek as much information as possible as to their causes. The first of these surveys was made in Waslington, D. C. This was followed by limited inspections in Baltimore, Md., and in some other localities in the Middle Atlantic States. Finally, an extensive survey was made of buildings in numerous towns and cities in Ohio, Michigan, Indiana, Illinois, and Kentucky, with the cooperation of representatives of the Public Buildings Administration of the Federal Works Agency, the Lime, Gypsum, and Portland Cement Associations, the Contracting Plasterers' International Association, the Operative Plasterers' and Cement Finishers' International Association, and others.

For the most part, the surveys were confined to public buildings of the monumental type, firstclass office buildings, hotels and apartment houses, department stores, ete., where the walls are generally of masonry construction. Although only limited inspections have been made of residential buildings, the knowledge gained from the larger buildings, where appearance and durability are given prime emphasis, has important bearing on the smaller buildings.

Throughout the inspections attention was paid not only to the materials used but also to the structural frame of the building, the construction bases, the kind of base coats, the job conditions or type of workmanship, the extent of failures and the age at which they first appeared, the explanations advanced for their occurrence, the methods of repairing the damage, and other factors that might have a bearing on the problem. Numerous samples of plaster were removed from the walls and ceilings when feasible and taken to the Bureau for chemical analyses and other determinations which will be described later. It was felt that only by these methods of considering the assembly as a whole and then resolving it into its individual components and finally correlating these to each other and to the whole could any definite decision be reached as to the cause of failure.

The purpose of this report is twofold. First, to give the results of the investigation of a particular kind of plaster failure that is characterized by the formation of blisters or bulges in the finish surface of plaster; and, second, to explain to the architect, enoineer, plastering contractor, plasterer, and others concerned with plastering, the precautions that should be exercised in new buildings to prevent such failures and in old buildings to repair the damage.

\section{Plaster and Plastering}

Before undertaking a description and discussion of the failures encountered, it seems advisable to explain some of the terms relating to plaster and plastering, especially for those not too familiar with building construction.

\section{Definition of Plaster}

When a dry material is mixed with water into a plastic mass that subsequently hardens to form the surface of interior walls or ceilings, the term plaster is applied to the material in any of its three stages-dry powder, plastic mass, or hardened surfacing.

\section{Definition of Plastering}

The word "plastering" (used as a noun) is given a broader definition than the word "plaster." Plaster is usually confined to the material. Plastering includes the plaster, the backing to which it is applied, the workmanship used in the application, and the subsequent history of the completed structure. Plastering may be divided into two kinds, depending upon whether the plaster is applied to a masonry backing or to a lath backing.

\section{Furring}

"Furring" is a trade term applied to a type of construction wherein there is provided an air space between the solid surface of a wall or ceiling and the plaster. The furring of a wall may be accomplished by the use of one of three different types of material-furring tile, furring strips and lath, and self-furring lath. It is sometimes desirable to make use of the principle of furring in the construction of ceilings. If the ceiling is the underside of the roof, or where excessive condensation may be expected, the insulation value of furring is desirable. If the floor is constructed in such a way that the beams project below it, and it is desired that the ceiling shall be plane, the plaster must be placed on lath suspended from the masonry.

\section{Base Coat}

The base coat may be defined as that portion of the plaster which is applied to the masonry or lathing base and which supports the finish coat. In three-coat plastering work the plaster is applied in three coats. "They are designated "scratch," "brown," and "finish," respectively.

The scratch coat is applied first. Its primary function is to act as a bonding coat to attach the body of the plaster securely to the lath or masonry. The properties required of a scratch coat are evidently dependent upon the nature of the backing to which it is to be applied. After it is applied, but before it lardens, this coat is scratched with a suitable tool. Thus the name, scratch coat. After it lias hardened, it is ready to receive the brown coat. The first coat is usually sanded. However, when the base is concrete, a plaster known to the trade as "bond plaster" is generally used as the first coat. It is essentially neat gypsum plaster and is recommended to be used without the addition of sand.

The brown, or second, coat forms the main body of plaster on lath. This coat also is generally 
sanded. The brown coat must be sufficicntly hard to form eithcr the wearing surfacc of the wall (if a sand-float finish is specified) or a solid backing for the finish coat.

In two-coat plastering work, the base (first coat) is applied witl sufficient material and pressure to cover well the lath or masonry, as the case may be, and then doubled back with the same mix to bring the plaster out to the desired thickness. The surface is then straightened to a true surface and left rough to receive the finish (second coat).

\section{Finish Coat}

The finish coat is usually applied when a smooth white finish is desired. This coat must be free from cracks, it must be hard enough to withstand reasonable abuse, and, above all, must present a pleasing appcarance. These requirements limit the composition. In order to produce the required hardness and the smooth white appearance, no ordinary sanded material can be used. Although thcre are several white-coat plasters, the one most generally applied is made from a lime putty mixed with calcined gypsum (also known as gypsum gaging plaster or plaster of paris). The lime used in preparing the putty, the application of the white coat, and its subsequent behavior will be taken up in detail in this paper; and, in fact, will be the main theme of this publication.

\section{Description of Failures}

\section{Principal Gharacteristics}

The type of failure that was found again and again throughout the inspection trips is separate and distinct from cracks resulting from movement of or within the structural frame, damage from leaks, and similar difficulties that always have becn and always will be encountered in plaster work.

The principal characteristics of this particular kind of failure are as follows:

(a) Bulges (large blisters) are formed with the finish surface convex. This may be the result of (1) separation of the smooth or white skim coat from an underlying layer of white coat, (2) separation of the entire white coat from either the sanded brown coat or coat of bond plaster, (3) in a few instances, separation of sand-lime-plaster base coat from the construction base.

(b) Several years (from about 5 to 15 , but usually from 8 to 9 ) elapse before the blisters or bulges begin to appear, and thereafter the number and extent of failures increase as the age of the building increases.

(c) The failures occur more extensively and rapidly during the warm weather of summer and during periods of high relative humidity.

(d) There is a marked similarity in the failures, regardless of the kind of plaster base coat, construction base, varying job conditions, and type of workmanship.

\section{Building Components and Plastering}

It seems desirable to group together a brief description of the various structural members of the numerous buildings inspected and of the different kinds of plastering where failures occurred. This has becn done in table 1 where the descriptions of the structural members of the building have been subdivided as to the framing, floor slabs, outside walls, and interior partitions; and the kinds of plastering, as to the plaster bases and plaster work. It should be emphasized that the surveys were confined primarily to public buildings

TABLE 1. Description of the various structural members of the buildings inspected and of the different kinds of plastering where failures occurred

Struetural members of tbe buildings

\begin{tabular}{|c|c|c|c|}
\hline Framing & Floor slabs & Outside walls & Interior partitions \\
\hline $\begin{array}{l}\text { Structural steel, fireproofed. } \\
\text { Structural steel and reinforced con- } \\
\text { crete. } \\
\text { Reinforced concrete. }\end{array}$ & $\begin{array}{l}\text { Reinforced concrete. } \\
\text { Concrete joists with tile fillers. } \\
\text { Concrete joists with sheet-metal-lath fillers. } \\
\text { Concrete joists with expanded-metal-lath } \\
\text { fillers. } \\
\text { Reinforced concrete, flat slabs. }\end{array}$ & $\begin{array}{l}\text { Brick. } \\
\text { Brick, furred witb tile. } \\
\text { Brick and terra cotta, furred with tile. } \\
\text { Stone and brick, furred with tile. } \\
\text { Stone and terra cotta, furred with tile. } \\
\text { Stone and brick, furred with metal lath. }\end{array}$ & $\begin{array}{l}\text { Hollow tile. } \\
\text { Gypsum block. } \\
\text { Metal lath plastered on botb } \\
\text { sides, } 2 \text { inches thick. }\end{array}$ \\
\hline
\end{tabular}

Kinds of plastering

Plaster bases

Ceilings, determined by construction of floor slabs:

Monolitbic concrete.

Concrete joists with tile fillers.

Concrete joists with sheet-metal-lath fillers.

Concrete joists witb expanded-metal-lath fillers.

Suspended metal lath attached close to bottom of concreted joist (furred

type).

Ccilings-suspended sheet or expanded metal latb.

tside walls and interior partitions:

Brick.

Hollow tile.

Furred metal lath.

Gypsum block.

Gypsum plaster (2-incb solid partitions).
Plaster work
One-coat work:

Wbice coat applied directly to conerete. wo-coat work:

First coat of sanded plaster, doubled back; second coat of wbite-coat finisb (mostly over masonry-finisb construction).

Same, but sand-float.

Gypsum bond plaster over concrete, finisbed with wbite coat.

Three-coat work:

Scratch, brown, and finish coats (mostly over metal lath but also orer masonry).

Scratch, brown, and sand-float finisb coats. 
of the monumental type where walls are generally of masonry construction. Therefore, the woodframe type of construction is not included in table 1. Although only limited inspections have been made of residential buildings, they have, nevertheless, revealed that white-coat-plaster failures occur in such buildings; for example, within the white coat applied to gypsum plaster on gypsum lath. Failures have also been noted both where the plastering was over wood lath and where it was on masonry construction.

\section{Typical Illustrations}

Figures 1 to 13,22 to 24 , and 27 to 29 have been selected that illustrate typical ways in which the plaster was failing. These will be described and interpreted in sufficient detail to bring out certain of the salient factors involved.

\section{(a) On Concrete Beams and Pilasters}

Failures in the white coat of plaster over concrete bases were of frequent occurrence. Figure 1 shows a series of bulges on the side of a concrete beam. In this case, the bulging was confined entirely to the white coat. On breaking these bulges it was found that the underlying coat of gypsum bond plaster (which had been applied directly over the concrete) had been well scratched, was hard, and still attached firmly to the beams.

Figure 2 shows bulging white coat along the side of a concrete beam located above a door in an inside stairway of an eight-story fireproofed apartment house built in 1924. Here, again, the failure was confined to the white coat; the underlying gypsum bond plaster was still adhering tightly to the concrete base. Failures are also taking place in the white coat on the ceilings and side walls. There has been no trouble with the underlying base coats of sanded gypsum plaster. Failures started in this building about 7 years after the building was erected.

When figure 3 was taken, new bowling alleys were being installed, and, consequently, no effort

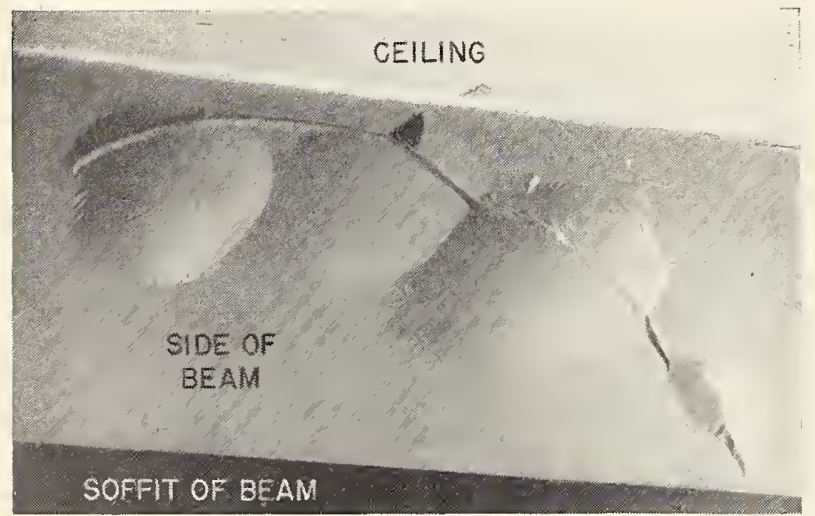

Figure 1. A series of bulges in white coat along the side of a concrete beam, caused by the expansion attending the slow hydration of free $\mathrm{MgO}$ in the hydrated lime used in preparing the white coat.

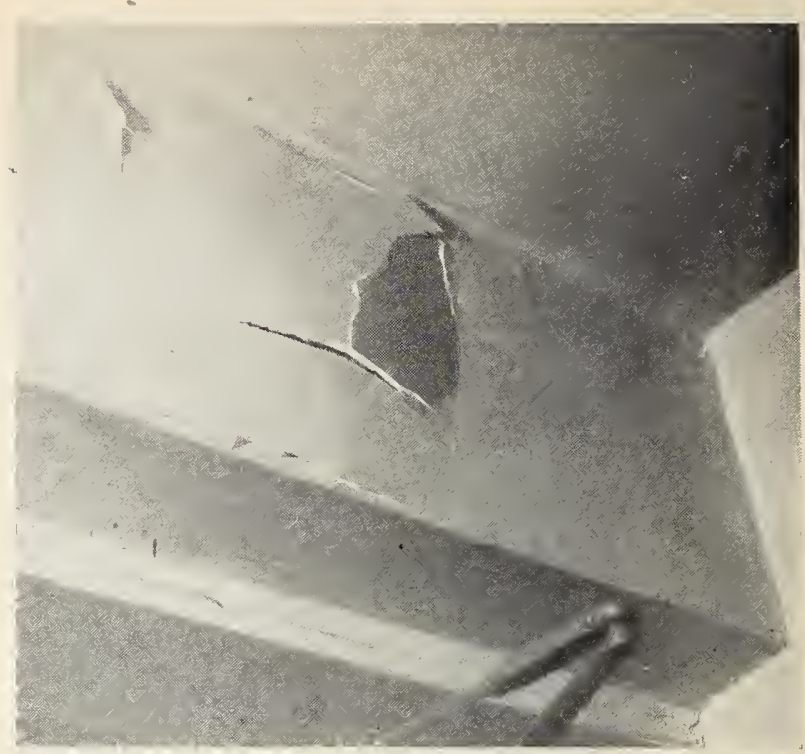

Figure 2. Bulging white coat along the side of a concrete beam located above the door of an inside stairway in an eight-story fireproofed apartment house.

The underlying gypsum bond plaster was still adhering tightly to the concrete base.

was being made to keep in repair the white-coat finish. In fact, the failures had occurred so frequently that the owner of the bowling alleys found it cheaper and more advantageous to hang velvet drapes in front of the concrete beams to hide their unsightly appearance rather than to replaster the beams repeatedly. Inasmuch as the bulged and loose plaster had been removed before the concrete beams were photographed, the picture reveals where the failures had occurred. For the most part they were at the bond between the successive layers of white coat, applied to straighten up the beam, rather than between the white coat and scratch coat of neat gypsum bond plaster. Only in very limited areas was there any separation of the bond plaster from the concrete.

Figures 1, 2, 3, and 4 are typical of those failures on concrete beams that were observed throughout the surveys. Troubles of a similar nature occurred in instances where no bond plaster was used and the white coat was applied directly to the concrete, even where the concrete appeared to be sufficiently rough for satisfactory bonding. Inquiry invariably revealed that the bonding had been entirely adequate for 5 to 15 years prior to the formation of bulges and the shearing of the white coat from the underlying base. Bulges in the white coat were also observed where a sanded plaster was used in lieu of bond plaster; and, as with the bond plaster, the failures were almost invariably in the white coat and not in the bond between the underlying sanded plaster and the concrete base. In those instances where the bond plaster had been applied to a smooth dense concrete, and especially where the oil from the forms had not been removed, the failures were mostly between the bond plaster and the con- 


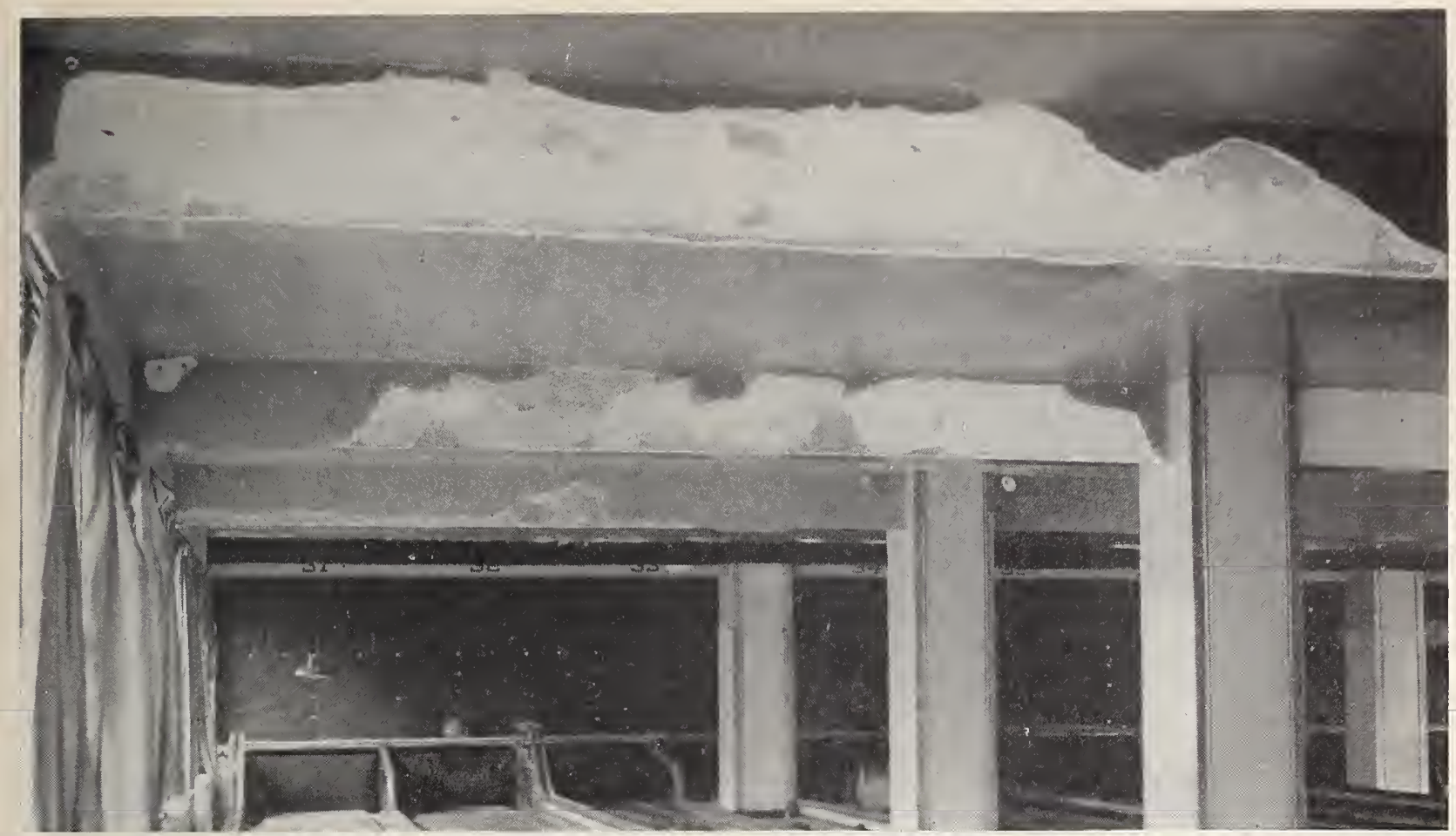

Figure 3. Failures in white coat along sides of concrete beams over bowling alleys.

The failures caused by the expansion of the white coat were confined almost entirely to loosening of the bond either between successive layers of white coat or between the white coat and the gypsum bond plaster. Only in very limited areas was there any separation of the bond plaster from the concrete.

crete. In these eases, wherc the bond between the plaster and the concrete was not so strong as that between the bond plaster and the white coat, the bond plaster was pulled from the concrete by the expanding white coat.

Thus, therc was a marked similarity in the failures, regardless of the type of plastering over the concrete. It is believed that such whitecoat-plaster failures are largely responsible for the conception held by architects and others that plaster does not adhere satisfactorily to concrete. Too often the fact is overlooked that the failure is primarily in the white coat and that the underlying bond coat is still adhering firmly to the concrete. Without careful observation, the bond plaster, because of its color, may be mistaken for the concretc base.

Figure 5 shows a large bulge of the white coat on a concrete pilaster.

\section{(b) On Ceilings}

Typical defects of bulging, separation of the final white coat from an undercoat of white coat, and separation of the cntirc whitc coat from the brown or bond coat were also observed on ceilings.

Figure 6 shows a white-coat blister, cracked and bulging from an undcrlying sanded gypsum brown coat on a plastered ceiling, but still held

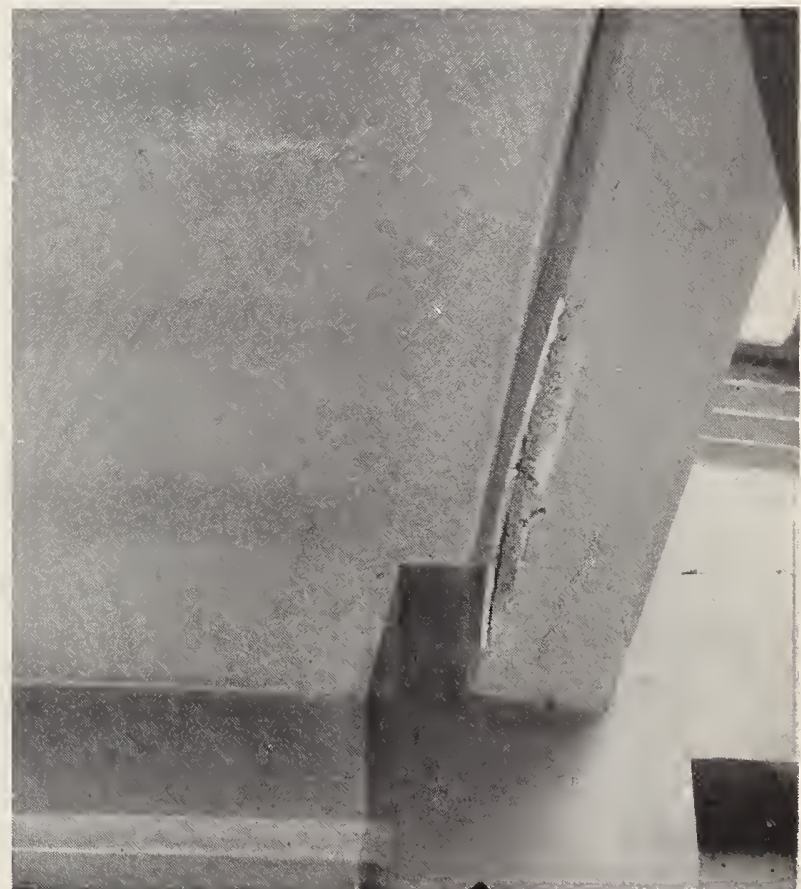

FIGURE 4. Bulging white coat along the edge of the soffit and side of a concrete beam in an office building.

Note the old patch in the white coat in the ceiling. 


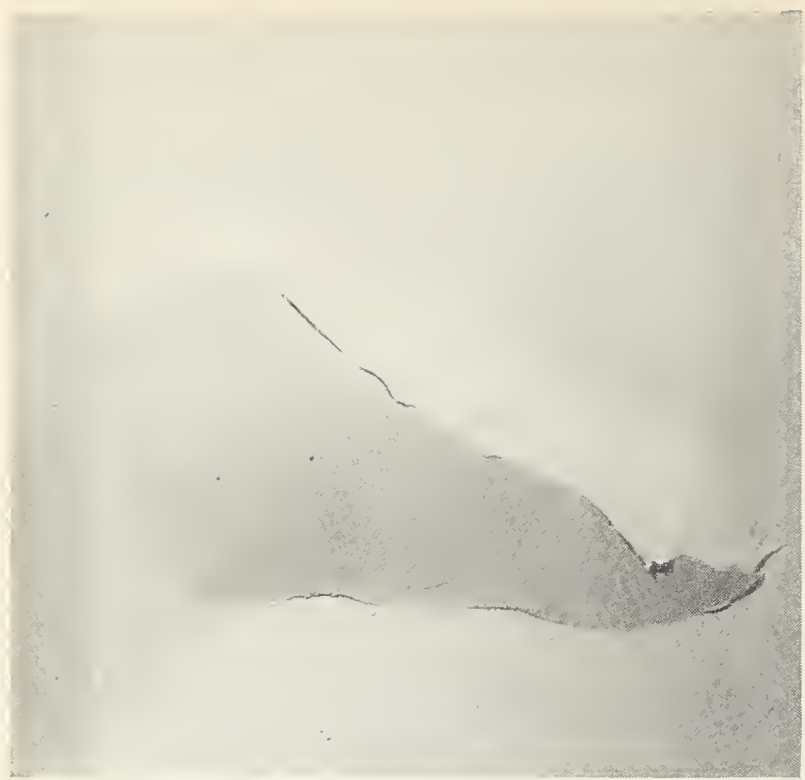

FIGURE 5. Large bulge of white coat on a concrete pilaster in a school building.

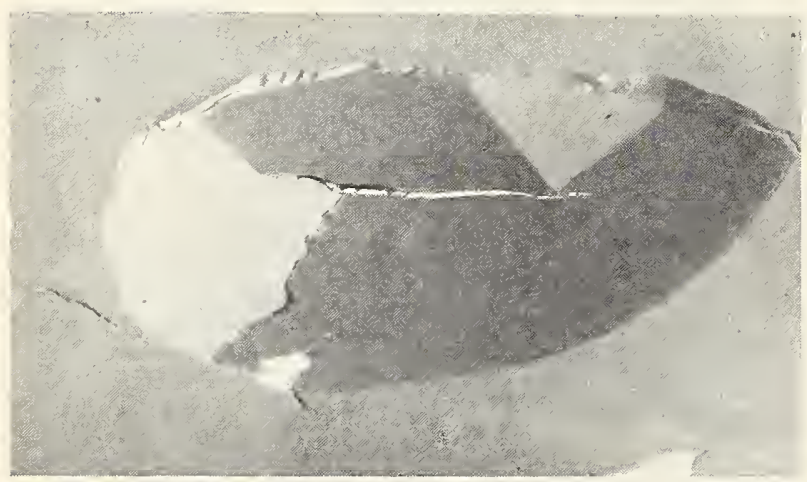

FIGURE 6. Cracked bulge of white coat on a ceiling, still held suspended by a film of paint.

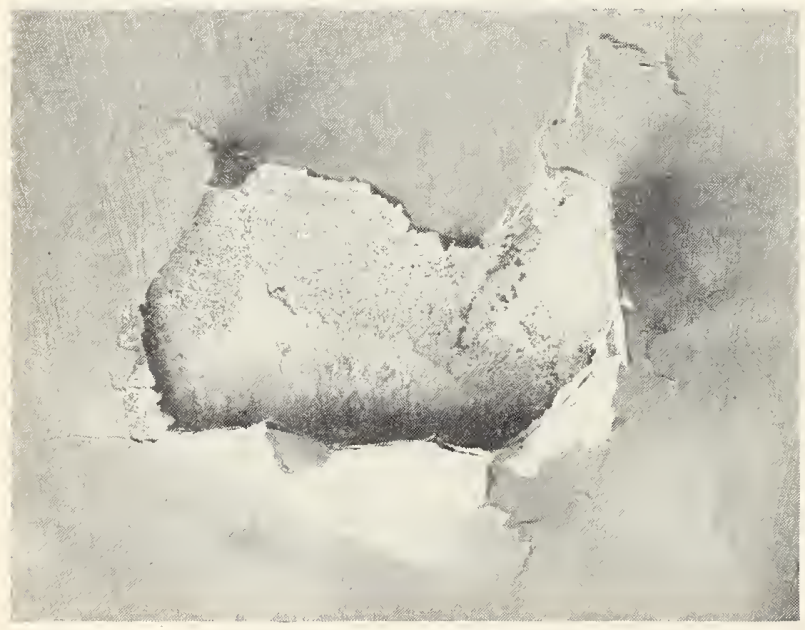

FIGURE 7. All that remained after a bulge of white coat fell from a ceiling of an office building.

Note the firm underlying brown coat of sanded gypsum plaster and a thin layer of white coat still intact.

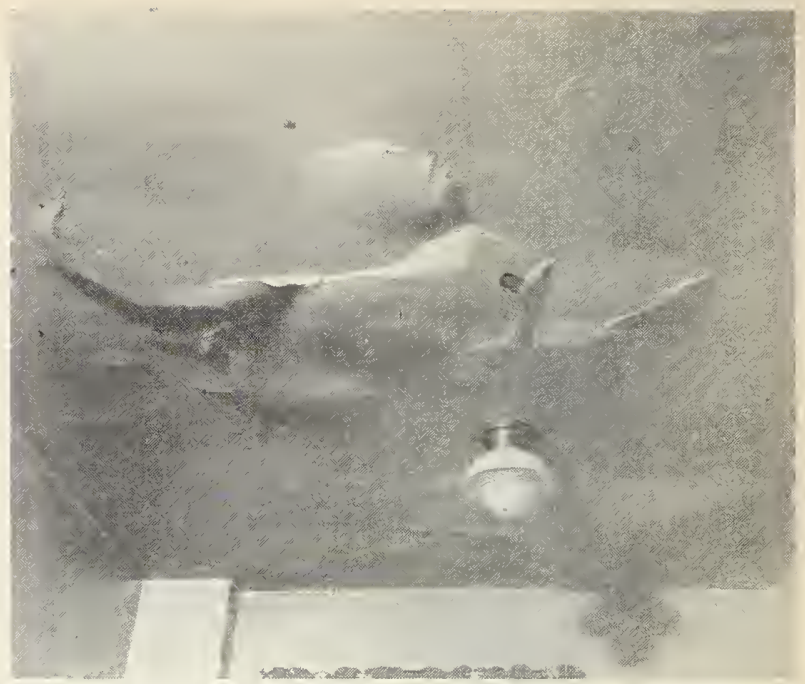

FIGURE 8. A kitchen ceiling in an apartment house; revealing pronounced bulging in the white coat, caused by expansion.

Note the small patehes previously applied.

suspanded by a film of paint. The scratch and brown coats remained firmly bonded to the base of concrete joists with hollow-ceramic-tile fillers.

Figure 7 shows the loosely held remains of a shattered blister after the missing portion had fallen from the ceiling, thus revealing the firm underlying brown coat of sanded gypsum plaster and a thin layer of adhering white coat still intact. The plaster base of the ceiling was composed of concrete joists with hollow-ceramic-tile fillers.

The surveys disclosed that separation of the white coat occurs irrespective of whether the plaster is applied over the concrete joists or the hollow-tile fillers.

An example of pronounced bulging of white coat is illustrated in the photograph of a kitchen ceiling in an apartment house (fig. 8). Figure 9

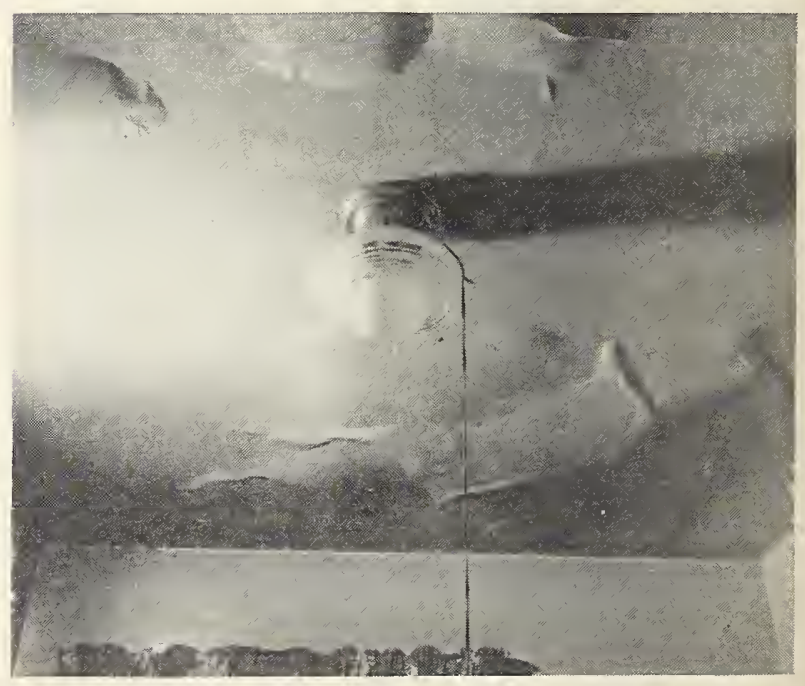

FIGURE 9. A more detailed photograph of the bulges shown in the background of figure 8. 
presents in greater detail the bulge in the background of figure 8. Trouble had started about 7 years after the building was erected and had continued for 18 years up to the time of the inspection. White-coat-plaster failures had occurred on the side walls also. There had been very little trouble with the sanded gypsum base coats on ceilings and side walls.

\section{(c) On Side Walls}

Figure 10 shows a large bulge of white coat protruding from a sanded base coat on a side wall and extending downward from the plaster moulding for about $2 \frac{1}{2}$ feet. There was no evidence of poor workmanship in the plastering. The 12 story building was of reinforced-concrete construction with hollow-ceramic-tile partitions. No details were obtained as to when failures began nor as to their extent each year, but at the time of the inspection, 27 or 28 year's after the building was completed, a great deal of trouble was being experieneed with the white-coat plaster throughout the building. White-coat-plaster failures were as extensive on the ceilings as on the side walls. The gypsum sanded base coats on the side walls were in good condition.

Figure 11 shows the bulging of white coat, involving separation of this coat from the gypsum sanded base coat within an area of about 1 square yard. This is a photograph of the side wall of an inside stairway of an apartment house where there were several similar failures in the white coat:

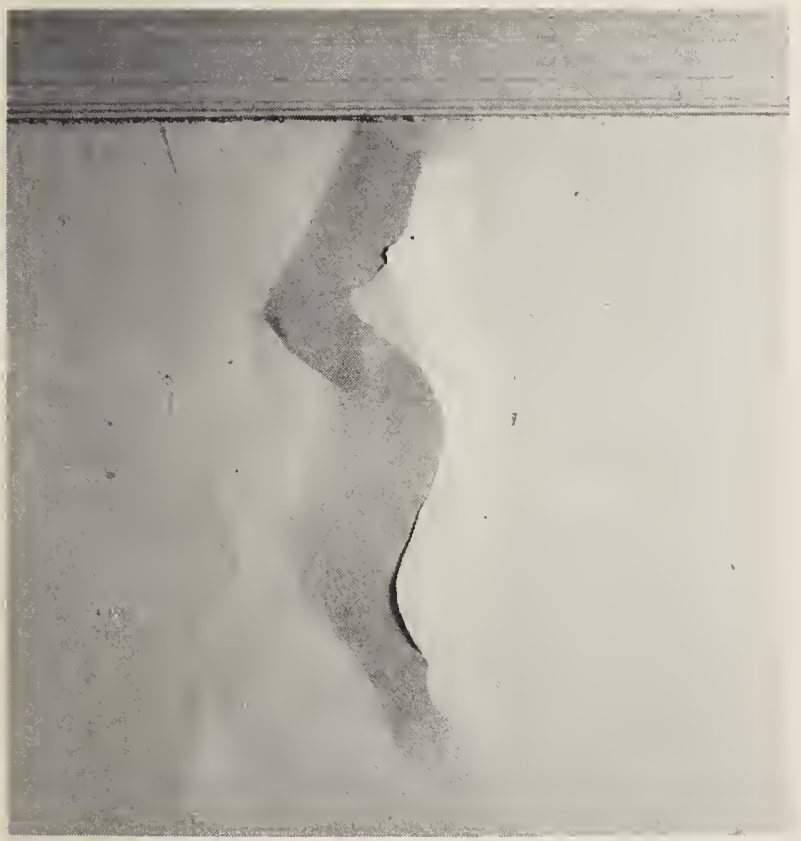

Figure 10. A large bulge of white coat extending about $2 \frac{1}{2}$ feet downward from a cast gypsum plaster moulding.

The photograph was taken in a corridor of a 12-story building of reir forcedconcrete construction with ceramic-tile partitions. The building, originally designed and occupied as a hotel, was later convorted to an office building. No cxpense had been spared in the plastering work.

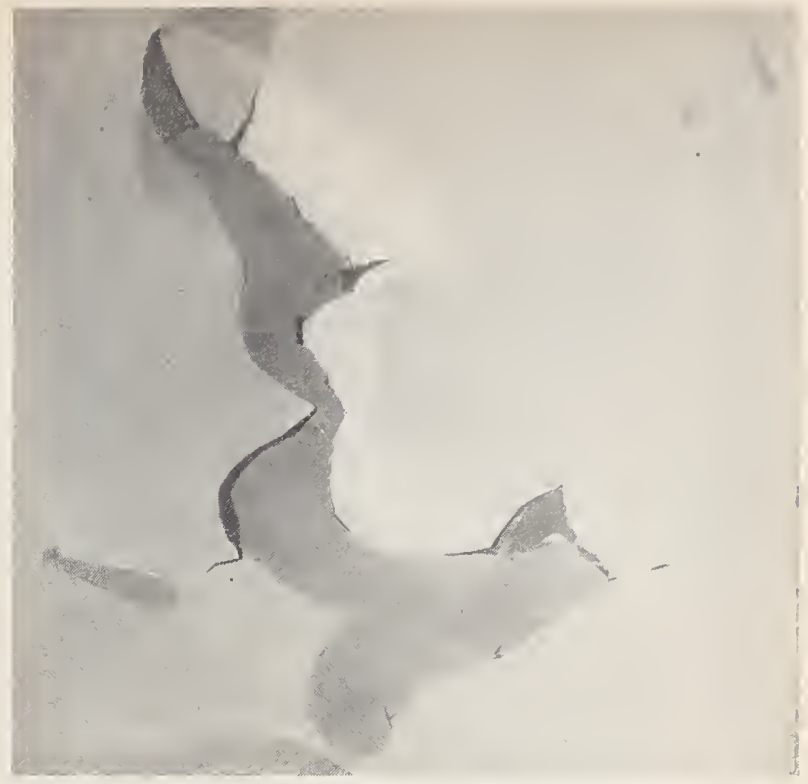

FIGURE 11. Bulging of white coat on a side wall, involving separation from the sanded gypsum base coat within an area of about 1 square yard.

Figure 12 shows a bulge of white coat on the side wall of another building. In this case the backing was wood lath.

An example of extensive white-coat failure is shown in figure 13 . This is a side-wall panel in a shop of a store and office building. The gypsum brown coat underneath this white coat was firm and well bonded. The white coat in an adjoining panel had been replaced, and the members of the inspection committee were told that the bulges in this pancl were even more pronounced than those shown in figure 13.

Up to this point, with the exception of figure 12 , the illustrations are confined to white-coat failures where the plaster bases were of masonry construction. This should not be construed to indicate that failures were not also occurring on other bases,

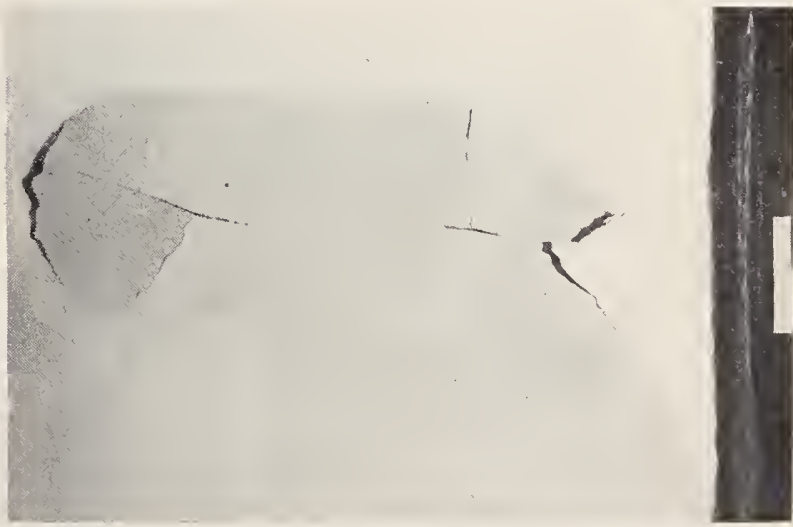

Figure 12. Bulge of white coat on the side wall next to a door jamb.

The firm base coat of sanded gypsum plaster was applied orer wood lath. 


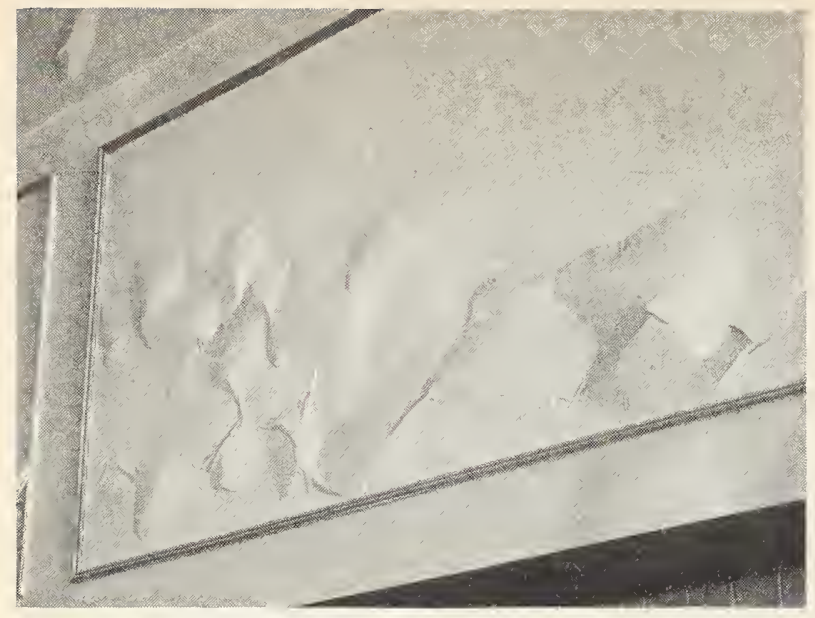

Figure 13. Series of white-coat bulges along the side wall of a plastered panel in a shop of a store and office building.

such as metal lath. In fact, numerous failures were observed where the base-coat plasters had been applied over metal lath on ceilings where the floor slabs were of concrete joists with both sheetand expanded-metal-lath fillers. Failures also occurred where the metal lath was of the furred type and attached close to the bottom of the concrete joists. In several instances, failures started in such ceilings prior to those on the side walls where the sanded plaster had been applied to ceramic furring tile. The manager of a building where there were two types of construction stated that there was no appreciable difference between the extent of white-coat-plaster failures on ceilings having ceramic-tile fillers and on those with metallath fillers.

\section{Discussion of the Formation and Subsequent History of White-Coat Plaster}

The formation of a bulge in the coating on a rigid nonyielding backing must be accompanied by an increase in the surface area of the coating. In white-coat plaster, a rigid brittle substance, such an increase can be accomplished only by expansion of the material in the bulge. It is shown later that plaster backings are incapable of contracting sufficiently to cause bulge-type white-coat-plaster failures. As expansions are often the result of chemical reactions, it is proposed (1) to discuss the composition, preparation, and properties of the materials used in the white coat, (2) to describe briefly the preparation and application of the white coat, (3) to trace the chemical reactions that take place from the time the white coat is prepared and applied until long after it has hardened, (4) to point out which of these reactions most definitely causes an expansion, and (5) to correlate the field observations with these various factors. Such considerations should clarify the reasons for making certain chemical analyses, computations, and auxiliary experiments-such as heat-of-solution tests and thermal and X-ray analyses-on samples of white-coat plaster.

\section{Materials Used in Preparing the White Coat}

The usual white coat is prepared from a lime putty gaged with plaster of paris (gypsum gaging plaster). Lime putty may be prepared either by slaking quicklime on the job with an excess of water or by soaking a dry commercial finishing hydrated lime with water.

\section{(a) Quicklime}

Lime, chemically speaking, is calcium oxide $(\mathrm{CaO})$, but the commercial article may differ widely from this composition. The burning of lime, which dates back to early antiquity, may be defined as the process of converting limestone into lime through the agency of heat. Carbon dioxide $\left(\mathrm{CO}_{2}\right)$ is liberated during the process.

The term "limestone" is used to describe a class of sedimentary rocks varying in composition from almost pure calcium carbonate to a mixture of calcium and magnesium carbonates in equal molecular proportions (dolomite). Any gradation between these limits may be found; and, in addition, all limestones contain impurities. The chemical composition of a lime depends on that of the limestone from which it was made. Consequently, only those limestones may be used from which a marketable lime can be produced. Because of the loss of about half the weight of the stone as carbon dioxide during the burning, the proportion of every other constituent will be nearly doubled in the lime. The amount of impurities (primarily silica and oxides of iron or aluminum) permissible in a hydrated lime is small, certainly not over 5 percent ( $2 \frac{1}{2}$ percent in the stone). ${ }^{3}$ Lime may contain from 0 to 42 percent of magnesium oxide $(\mathrm{MgO})$, depending on whether the lime was prepared from pure calcium carbonate or pure dolomite. When properly burned and fresh from the kiln, lime should contain no water and less than 1 percent of carbon dioxide. ${ }^{4}$

The material as it comes from the kiln is frequently called "quicklime" to distinguish it from "slaked lime."

There are three factors essential to the process of lime burning (1) the limestone must be heated to the temperature of dissociation of the carbonates, (2) this temperature must be maintained for a certain length of time, and (3) the liberated carbon dioxide must be removed.

\footnotetext{
${ }^{3}$ Both Federal Specification SS-Q-351 for quicklime (for) structural pur-
poses (1930) [3] and American Society for Testing Materials, ASTM C5-26 poses (1930) specify that the total CaO $+\mathrm{MgO}$ in quicklime shall be not less than 95 [4], specify that the total CaO+MgO in quicklime shall be not less than percent, calculated on the nonvolatile basis. This purity is, in turn, regiven in Federal Specification SS-I, 351 for hydrated lime (for) structural purposes (1930) [5] and ASTM Specifications C6-46T [6], C206-46T [7], and C207-46T [8].

1 Although the carbon dioxide is usually less than 1 percent as the lime comes from the kiln, specifications such as SS-Q-351 [3] and ASTM C5-26T [4] allow as much as 5 percent of $\mathrm{CO}_{2}$ if the sample be taken at the plant and 7 perent if the $\mathrm{CO}_{2}$ of the atmosphere.
} 
Many experiments have been made to detcrminc the dissociation temperature of calcium carbonate, and the lime-burning reaction has become the classical example of a gas-solid equilibrium involving a distinct chemical reaction:

$$
\mathrm{CaCO}_{3} \rightleftharpoons \mathrm{CaO}+\mathrm{CO}_{2} \text {. }
$$

The system consists of two components in thrce phases (two solid and one gaseous) and is therefore monovariant. It can be shown readily that the dissociation pressure at equilibrium is ind cpcndent of the amounts of the separate phases and depends solely on the temperature. Thus, when calcium carbonate is heated, the dissociation pressure increases. The thermal dissociation of calcium carbonate has been studied by numerous investigators, and Kelley and Anderson [9] have shown that the better results of the dissociation-pressure data may be divided into two groups. They state that those of Johnston [10], Smyth and Adams [11], and Dutoit [12] are in good agreement and indicate that in the dissociation of $\mathrm{CaCO}_{3}$ (solid) into $\mathrm{CaO}$ (solid) and $\mathrm{CO}_{2}$ (gas), the dissociation pressure of $\mathrm{CO}_{2}$ reaches $760 \mathrm{~mm}$ of $\mathrm{Hg}$ $(1 \mathrm{~atm})$ at a temperature of $898^{\circ} \mathrm{C}\left(1,648^{\circ} \mathrm{F}\right)$. The data of Andrussow [13], von Kohner [14], and Tamaru, Siomi, and Adati [15] are likewise in good agreement, but consistently show higher pressures for a given temperature than do those of the former group of workers. Kelley and Anderson have shown that if the average of both groups is takcn, the calculated value for the pressure of $\mathrm{CO}_{2}$ is 1 atmosphere at $884^{\circ} \mathrm{C}\left(1,623^{\circ} \mathrm{F}\right)$.

The corresponding temperature for magnesium carbonate $\left(\mathrm{MgCO}_{3}\right)$ is very much lower, but the thermal dissociation values are in considerable disagreement, largely because of the difficulty in attaining equilibrium conditions. Kelley and Anderson [9] have also critically analyzed the data for $\mathrm{MgCO}_{3}$ and show that the equilibrium decomposition pressure of $\mathrm{MgCO}_{3}$ apparently reaches $1 \mathrm{~atm}$ at $408^{\circ} \mathrm{C}\left(766^{\circ} \mathrm{F}\right)$, which is low compared with $884^{\circ} \mathrm{C}\left(1,623^{\circ} \mathrm{F}\right)$ for $\mathrm{CaCO}_{3}$. It has been shown, however, in studies by Ralston, Pike, and Duschak [16] that at $1 \mathrm{~atm}$ an appreciable rate of decomposition is not reached below $555^{\circ} \mathrm{C}\left(1,031^{\circ}\right.$ F). In other words, because of the slowness of decomposition, $\mathrm{MgCO}_{3}$ may be consideraby superheated.

Kelley and Anderson [9] state "It it possible then virtually to complete the reaction $\mathrm{MgCO}_{3} . \mathrm{CaCO}_{3}$ $=\mathrm{MgO}+\mathrm{CO}_{2}+\mathrm{CaCO}_{3}$ at temperatures below those where the reaction $\mathrm{CaCO}_{3}=\mathrm{CaO}+\mathrm{CO}_{2}$ takes place to an appreciable extent.

"In the case of mixed compounds such as dolomite the decomposition temperatures of the less stable constituent should be somewhat higher than those in the table. The increase in temperature may not be expected to be large, however, since the free energy of formation at $298.1^{\circ}$ of such compounds from the carbonates, that is, $\mathrm{MgCO}_{3}+\mathrm{CaCO}_{3}=\mathrm{MgCO}_{3} \cdot \mathrm{CaCO}_{3}$ is small with respect to the free energies of decomposition of the individual carbonates . . it would scem that $100^{\circ}$ or $200^{\circ}$ incrcase in temperature is necessary to overcome the increased stability due to compound formation in decomposing the less stable constituent of a mixed carbonate." The table referred to gives the decomposition temperatures of $\mathrm{MgCO}_{3}$ and $\mathrm{CaCO}_{3}$ as 681 and $1,157^{\circ} \mathrm{K}$, r'cspcctively. 'These tempcratures correspond to $408^{\circ}$ and $884^{\circ} \mathrm{C}\left(766^{\circ}\right.$ and $\left.1,623^{\circ} \mathrm{F}\right)$, respectively. It is evident that in the lime-buming of dolomite, the magnesium earbonate is decomposed into $\mathrm{MgO}+\mathrm{CO}_{2}$ before the calcium carbonate has been completely decomposed.

Decomposition temperatures, melting points, and transition temperatures may be approximately located by differential thermal analysis. 'This is done by heating at a uniform rate the matcrial under investigation side by side with a similar body of inert material and continually measuring the temperature differences between the two substances. When a reaction occurs which absorbs or evolves heat, the measured temperature difference will deviate sharply from that previously established by the differences in thcrmal conductivity, heat capacity, and density of the two substances. This technique has frequently been described in detail [17]. $A s$ it is a dynamic process, decomposition temperatures, etc., determined by differential thermal analysis agree only approximately with data obtained under equilibrium conditions. However, much valuable information can be extracted from the heating curves so obtained. The technique of thermal analysis has been applied, in this laboratory, to many of the substances discussed in this paper. Figure 14 shows heating curves pertinent at this point in the discussion. The decomposition temperature of calcite $\left(\mathrm{CaCO}_{3}\right)$, taken as the lowest point of the differential heating curve (1), is $917^{\circ} \mathrm{C}\left(1,683^{\circ} \mathrm{F}\right)$, $33^{\circ} \mathrm{C}\left(59.4^{\circ} \mathrm{F}\right)$ higher than the average equilibrium value of $884^{\circ} \mathrm{C}\left(1,623^{\circ} \mathrm{F}\right)$.

The existence of the superheating of magnesium carbonate is demonstrated in figure 14 where its heating curve (2) shows a (nonequilibrium) decomposition temperature of $635^{\circ} \mathrm{C}\left(1,175^{\circ} \mathrm{F}\right)$ for magnesite $\left(\mathrm{MgCO}_{3}\right)$. The temperature is changed only slightly by the presence of calcite. The heating curve of an equimolar mixture (curve 3 ) shows decomposition temperatures of $625^{\circ} \mathrm{C}\left(1,157^{\circ} \mathrm{F}\right)$ and $935^{\circ} \mathrm{C}\left(1,715^{\circ} \mathrm{F}\right)$ for the magnesite and calcite, respectively.

The fourth heating curve in figure 14 demonstrates the increase in the decomposition temperature of dolomite over that of magnesite. In this test, dolomite (NBS Standard Sample 88) was decomposed in two steps, showing decomposition temperatures of $778^{\circ} \mathrm{C}\left(1,432^{\circ} \mathrm{F}\right)$ and $935^{\circ} \mathrm{C}$ $\left(1,715^{\circ} \mathrm{F}\right)$, respectively.

It should be necessary to heat a limestone only slightly above $884^{\circ} \mathrm{C}\left(1,623^{\circ} \mathrm{F}\right)$, the decomposition temperature of $\mathrm{CaCO}_{3}$, to convert both the magnesium and calcium carbonates completely to oxides. However, after the dissociation tempera- 


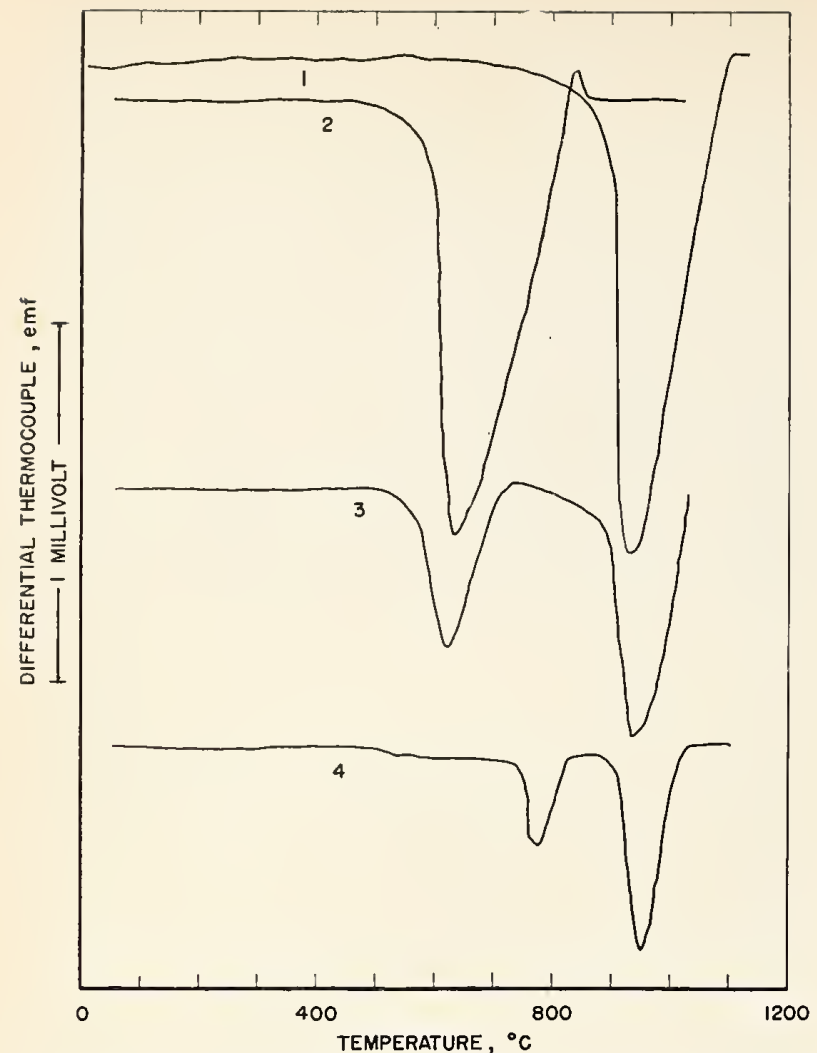

FIGURE 14. Four differential heating curves showing the dynamic decomposition temperatures of (1) calcite, (2) magnesite, (3) equimolar mixture of calcite and magnesite, and (4) dolomite.

ture has been reached, it must be maintained for some time in order to transfer the required amount of heat to the stone. The time required to transfer a given amount of heat, roughly speaking, varies inversely with the temperature difference. Consequently, it has been found economical to use as high a temperature as feasible in order to reduce the time required for burning, and the temperature of the ordinary lime kiln is usually somewhat in excess of $1,100^{\circ} \mathrm{C}\left(2,012^{\circ} \mathrm{F}\right)$ or even $1,200^{\circ} \mathrm{C}$ $\left(2,192^{\circ} \mathrm{F}\right)$. Increasing the temperature is also economically advantageous, because the dissociation pressure of calcium carbonate is an exponential function of the temperature. Consequently, an increase of temperature will cause a decided increase in the dissociation pressure and a correspondingly large reduction in the time required to produce a given quantity of lime.

When, however, the temperatures are raised too high, a phenomenon known technically as overburning occurs. The product becomes denser, is not as white as properly burned lime, but, most important of all, its activity toward water is reduced. These changes, in part, are caused by the chemical combination of the $\mathrm{CaO}$ with $\mathrm{SiO}_{2}$, $\mathrm{Al}_{2} \mathrm{O}_{3}$, and $\mathrm{Fe}_{2} \mathrm{O}_{3}$ to form a melt (somewhat similar to the clinker formed in the burning of cement) which reduces the pore space in the quicklime and surrounds particles of the oxides.
In general, for high-calcium limes, the smaller the percentage of impurities, the higher can be the temperature of burning without the formation of overbuined lime. But even with rather pure limestones, the activity of the resulting $\mathrm{CaO}$ to ward water to form calcium hydroxide, $\mathrm{Ca}(\mathrm{OH})_{2}$, is reduced somewhat as the temperature of burning is increased. Lime may be overburned by being heated for too long a time as well as at too high a temperature.

Magnesium oxide is far more susceptible to overburning than calcium oxide, and its reactivity may be decreased enormously thereby. For example, if overburning has not occurred, magnesium oxide, like calcium oxide, unites rapidly with water to form the hydroxide in the process known as slaking. Campbell [18] found that the hydration of $\mathrm{MgO}$ prepared by heating magnesite $\left(\mathrm{MgCO}_{3}\right)$ to a temperature of $800^{\circ} \mathrm{C}\left(1,472^{\circ} \mathrm{F}\right)$ is practically complete in 3 days. He found that a change in the reactivity of the magnesium oxide sets in between $1,000^{\circ}$ and $1,100^{\circ} \mathrm{C}\left(1,832^{\circ}\right.$ and $2,012^{\circ} \mathrm{F}$ ) and that $\mathrm{MgO}$ heated somewhat below $1,100^{\circ} \mathrm{C}\left(2,012^{\circ} \mathrm{F}\right)$ required nearly 3 months for complete hydration. Samples burned at $1,200^{\circ}$ C $\left(2,192^{\circ} \mathrm{F}\right)$ required 3 vears to become completely hydrated, and samples burned at $1,300^{\circ} \mathrm{C}$ $\left(2,372^{\circ} \mathrm{F}\right)$ and above were not completely hydrated even in 6 years.

It should be obvious, therefore, that by the time dolomite or a magnesium limestone has been hicated to the temperature necessary to convert the $\mathrm{CaCO}_{3}$ economically into $\mathrm{CaO}$ and $\mathrm{CO}_{2}$, roughly $1,100^{\circ}$ to $1,200^{\circ} \mathrm{C}\left(2,012^{\circ}\right.$ to $\left.2,192^{\circ} \mathrm{F}\right)$, the $\mathrm{MgO}$, formed at a much lower temperature, has been considerably overheated and its activity toward water greatly reduced. Also, the overburning of $\mathrm{MgO}$ increases with the time of heating and to a greater degree than that of $\mathrm{CaO}$. In addition, it would appear logical to assume that the $\mathrm{MgO}$ in the outer zones of a lump of the calcined dolomitic limestone would be overburned to a greater extent than the $\mathrm{MgO}$ in the inner zones, because of the temperature gradient, and consequently each lump of quicklime would be composed of $\mathrm{MgO}$ of varying degrees of reactivity toward water.

\section{(b) Hydrated Lime}

Dry hydrated lime is a product of comparatively recent origin. In the normal ${ }^{5}$ 'manufacture of dry hydrated lime, starting with the burnt quicklime as it comes from the kilns, the following operations must be performed: crushing, hydrating, screening, and packing. 'The object of crushing the quicklime is to produce a large surface for the action of water and to facilitate handling in the slaking process. The crushed quicklime is fed into a hydrator. Here it is mixed with water and agitated. In the liydration, the quicklime is broken down and slaking to a dry powder is accomplished by

5 Lime produced in this manner is designated "normal hydrate" by the American Society for Testing Materials. 
adding sufficient water to hydrate the active constituents. (If an excess of water is used in the normal hydration, an undesirably moist powder is produced). The fine, dry powder that comes from the hydrator must be classified either by screens or air separators to remove any core or other hard, coarse, particles of overburned lime that did not slake.

Chemical analysis of hydrated high-calcium lime as commercially produced shows that the combined water is almost sufficient for complete hydration. The $\mathrm{CaO}$, unless "dead-burned", is a very active constituent of quicklime and reacts so rapidly with water to form $\mathrm{Ca}(\mathrm{OH})_{2}$ that its hydration is complete or very nearly complete in the few minutes the material is in the hydrator.

On the other hand, chemical analysis of regularly hychated dolomitic lime shows that ordinarily only 55 to 65 percent of the water required for complete hydration is present. This large deficiency in the combined water is due to the fact that the inactive $\mathrm{MgO}$ of dolomitic quicklime (which contains $\mathrm{CaO}$ and $\mathrm{MgO}$ in a nearly equimolar ratio) has resisted hydration in the manufacture of the dry hydrate powder.

In 1927 Richardson [19] described a thermochemical method for determining the degree of hydration of magnesia and calcium oxide in commercially hydrated dolomitic limes. The method was based upon the fact that the two hydroxides have appreciably different dissociation temperatures. Thus, the percentages of magnesia and calcium oxide hydrated could be calculated from the weight losses when the temperature was raised just high enough to decompose first the magnesium hydroxide $\left(\mathrm{Mg}(\mathrm{OH})_{2}\right)$ and then the calcium hydroxide $\left(\mathrm{Ca}(\mathrm{OH})_{2}\right)$. By this method, Richardson analyzed 10 representative commercial dolomitic hydrates and concluded that in such hydrated limes the calcium oxide is largely hydrated, whereas the magnesia is only slightly hydrated.

Fox and Mathers [20] in 1934 determined by a similar method the amount of hydrated magnesia in nine hrdrated dolomitic limes. Their data indicated that only from 2.8 to 14.3 percent of the total magnesia was hydrated.

Wells and Taylor [2] in 1937 developed heat-ofsolution and ignition-loss methods for det ermining the degree of hydration of magnesia in hydrated dolomitic limes and in hydrated dolomitic lime putties. The heat-of-solution method was based on the fact that the components of hydrated limes have substantially different heats of solution. The observed heats of solution of the limes agreed closely with those calculated from the algebraic sums of the heats of solution of the individual constituents as computed from the chemical analyses. It was shown that in hydrated dolomitic lime $\mathrm{CaO}$ is generally completely hydrated, whereas the hychation of the $\mathrm{MgO}$ is far from complete. The degree of hrchration of the magnesia in six hydrated domolitic limes as received from the

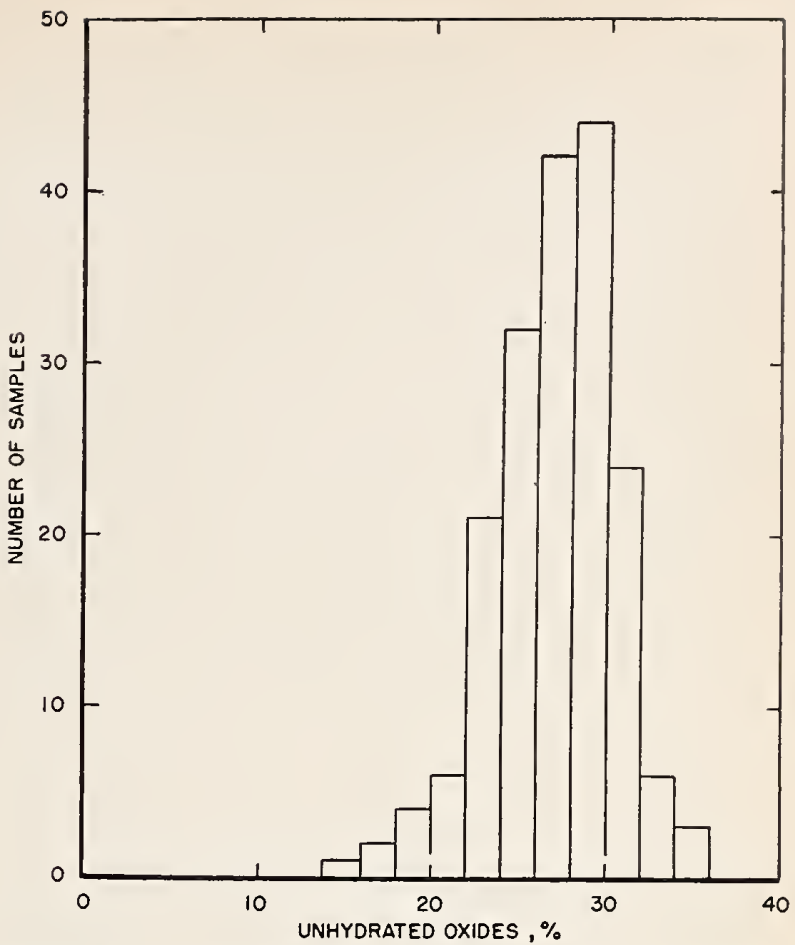

Figure 15. Distribution of the percentage of unhydrated oxides in $185(N)$ samples of regularly hydrated dolomitic lime, submitted to the Bureau for test from 1923 to 1940 , showing that the average amount $(\bar{X})$ was 26.98 percent with a standard deviation $(\sigma)$ of 3.04 percent.

manufacturers a veraged 12.5 percent (ranging from 3.3 to 22.8 percent).

More recently, in a study of the expansive characteristics of hydrated limes, Wells, Clarke, and Levin [21] showed that the amount of unhydrated $\mathrm{MgO}$ in 27 regularly hydrated dolomitic limes averaged 27.7 percent, with the range extending from 16.1 to 34.3 percent. Considering the total amount of magnesia in the sample, this means that on the average only 15.7 percent of the total magnesia was hydrated.

Calculations based on the analyses of the 185 regularly hydrated dolomitic limes submitted to the Bureau for test for compliance with Federal Specification SS-L-351 [5] from 1923 to $1940^{6}$ inclicated that the average amount of unhydrated $\mathrm{MgO}$ was 27.0 percent, by weight, and that the percentage of the total magnesia that was hydrated was 17.0 percent.?

Figure 15 shows the distribution of the per-

${ }^{6}$ Since 1940 most of the Government agencies have included the requirement of the proposed tentatire amendment to Federal specification SS-I 351 [5] that, "The total free (unhydrated) calcium ovide ( $\mathrm{CaO}$ ) and magnesium oxide (MgO) in the hydrated product shall not exceed 8 percent by weight (calculated on the 'as receired basis'),"

${ }^{7}$ in the calculation of the percentage of unhydrated oxide, the percentage of "free or extraneous water" should be ascertamed according to the proposed amendment to Federal Specification SS-I-351 [22] or according to the "Tentative revision of standard methods of chemical analysis of limestone, quicklime, and hydrated lime." IST II Designation: C25-14, submitted June lime, and hydrated lime." AST II Designation: C25-14, submitted June 1945; see ASTM Standards, part II, 1701 (1946) [23]. Howerer, inasmuch as the amount of "free or extraneous water" is usually but a few tenths of 1 percent, failure to determine and exclude this water in the calculation of
the percentage of unhydratcd oxides will make but slight difference in the the percentage of unhydratcd oxides will make but slight difference in the
ralue obtained-usually less than 1 percent, but always on the low side. ralue obtained-usually less than 1 percent, but always on the low side. set in a specification, nerertheless, it can be disregarded for a general surrey of the approximate degree of hydration of magnesia in regularly hydrated dolomitic lime produced commercially. 


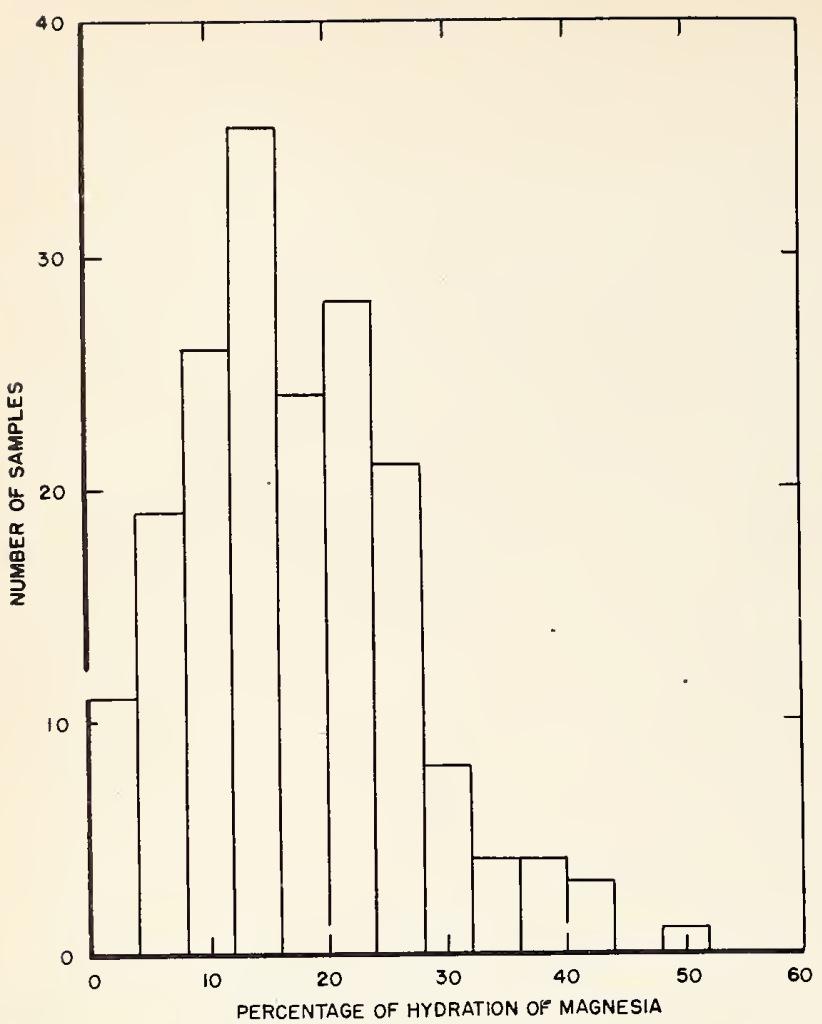

Figure 16. Distribution of the percentage of hydration of the magnesia in 185 ( $N$ ) samples of regularly hydrated dolomitic lime, submitted to the Bureau for test from 1923 to 1940 , showing that the average amount $(\bar{X})$ was 17.29 percent with a standard deviation $(\sigma)$ of 8.40 percent.

centage of unhydrated oxides for these 185 samples of regularly hydrated dolomitic lime; figure 16 , the distribution of the percentage of the total magnesia that was hydrated. In this figure, $N$ represents the number of samples; $\bar{X}$, the average percentage of unhydrated oxides (actually $\mathrm{MgO})$; and $\sigma$, the standard deviation calculated from the grouped data.

Differential thermal analysis also shows that the $\mathrm{MgO}$ of regularly hydrated dolomitic lime is only partially hydrated. In figure 17 are shown the heating curves of two hydrated limes and that of the partially dry material recovered from a sample of putty prepared from one of them. Curve 2 represents a hydrated dolomitic lime of the regular (or normal) type. The presence of $\mathrm{Mg}(\mathrm{OH})_{2}, \mathrm{Ca}(\mathrm{OH})_{2}$, and small amounts of $\mathrm{CaCO}_{3}$ is shown by characteristic deflections $(\mathrm{C}, \mathrm{D}$, and $\mathrm{E}$, respectively) in the heating curve. The same lime after 1 day of soaking as a putty is represented by curve $2 \mathrm{H}$. 'The presence of uncombined water not removed by the drying process is indicated by the first break in this differential heating curve. The small increase in the amount of $\mathrm{Mg}(\mathrm{OH})_{2}$ caused by hydration as a putty for 24 hours can be observed by comparing the relative sizes of the characteristic deflections of $\mathrm{Mg}(\mathrm{OH})_{2}$ and $\mathrm{Ca}(\mathrm{OH})_{2}$ in these curves. That only a small part of the potential $\mathrm{Mg}(\mathrm{OH})_{2}$ has been formed can be seen by comparing these curves with curve 1 which represents a completely hydrated dolomitic lime. In curve 1 the deflections characteristic of $\mathrm{Mg}(\mathrm{OH})_{2}$ and $\mathrm{Ca}(\mathrm{OH})_{2}$ are of approximately the same size.

It has been pointed out that a well-burned quicklime contains but a small quantity of unburned limestone, and in the usual lime plant this unburned material or core is discarded by the "pickers" or "sorters". With high-calcium limes the remaining carbonate in the core would be essentially $\mathrm{CaCO}_{3}$; with dolomitic limes it would also be largely $\mathrm{CaCO}_{3}$, because calcium carbonate has a much higher dissociation temperature than magnesium carbonate. In the handling of the quicklime, during the slaking process, and subsequently, the hydrated lime picks up additional carbon dioxide from the air. Usually, however, the quantity is small.

In a recent investigation of the expansive characteristics of hydrated limes, Wells, Clarke, and Levin [21] showed from analyses of eighty samples of hydrated lime that the content of $\mathrm{CO}_{2}$ averaged 1.42 percent. For the 27 regularly hydrated dolomitic limes, the average was 1.34 percent. The quantity of carbonate is roughly

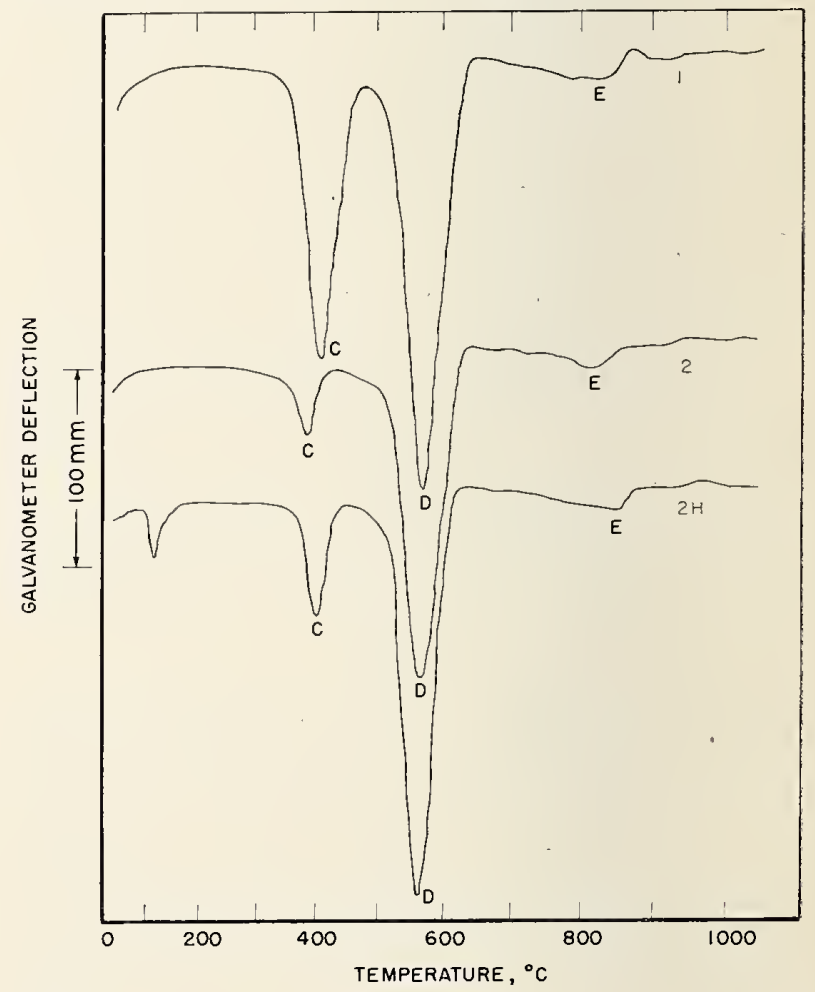

FIGURE 17. Differential heating curves of a completely hydrated dolomitic lime (1) in contrast to a regularly hydrated dolomitic lime (2) and a putty made therefrom $(2 H)$.

The small increase in the amount of $\mathrm{Mg}(\mathrm{OH})_{2}$ caused by hydration of the lime as a putty can be observed by comparing the relative sizes of the characteristic deflections, $\mathrm{C}$, of $\mathrm{Mg}(\mathrm{OH})_{2}$ at $400^{\circ} \mathrm{C}$ and, $\mathrm{D}$, of $\mathrm{Ca}(\mathrm{OH})_{2}$ at $580^{\circ} \mathrm{C}$ in these curves (2 and $2 \mathrm{H}$ ) and in curve 1 . Small quantities of $\mathrm{CaCO}_{3}$ are indieated by $\mathbf{E}$. 
twice that of the $\mathrm{CO}_{2}$. Even so, the percentage of carbonate in freshly prepared hydrated lime is small, and, as stated previously, the carbonate that is present is primarily $\mathrm{CaCO}_{3}$.

Thus, by independent methods, the following facts in regard to hydrated lime appear to be well established: (1) 'The combined water in commercial hydrated high-calcium lime is sufficient or almost sufficient for complete hydration because $\mathrm{CaO}$ reacts rapidly and practically completely to form $\mathrm{Ca}(\mathrm{OH})_{2}$, (2) only 55 to 65 percent of the water required for complete hydration of regularly hydrated dolomitic lime is present, because of the slowness of hydration of $\mathrm{MgO}$ in the ordinary hydrator, (3) the calcium oxide of hydrated dolomitic lime, like the $\mathrm{CaO}$ in hydrated highcalcium lime, is generally completely hydrated, but the magnesia is only slightly hydrated, (4) all commercial hydrated limes contain some calcium carbonate with little or no magnesium carbonate, and (5) all commercial hydrated limes contain certain other impurities, such as silica and oxides of iron and aluminum.

\section{(c) Gypsum Gaging Plaster}

Gypsum gaging plaster is variously known as plaster of paris or as calcined gypsum. Calcined gypsum when pure is essentially hemihydrate and has the formula $\mathrm{CaSO}_{4} \cdot \frac{1}{2} \mathrm{H}_{2} \mathrm{O}$. The article of commerce, however, may and usually does vary in composition from chemically pure hemihydrate. Inasmuch as the gypsum, $\mathrm{CaSO}_{4} .2 \mathrm{H}_{2} \mathrm{O}$, from which it is made (by heating and driving off $1 \frac{1}{2}$ molecules of water) may contain impurities, such as limestone, iron oxide, clay, and silica, it is to be expected that these materials will be found in the calcined gypsum. Some gaging plasters may also contain a small percentage of anyhdrous $\mathrm{CaSO}_{4}$, present either as the mineral, natural anhydrite, in the gypsum, or formed when the gypsum was dehydrated beyond $\mathrm{CaSO}_{4} \cdot \frac{1}{2} \mathrm{H}_{2} \mathrm{O}$.

\section{Preparation of the Lime Putty}

To prepare lime for use in the white-coat plastering operation, it must first be made into a putty. Because the finish coat must be applied in a thin layer over a dry brown coat, it is essential that the wet mix be sufficiently plastic; otherwise, it is almost physically impossible to use the mix for finish-coat work. Plasticity, therefore, has an important bearing on labor cost. Since the usual gypsum gaging plaster is not plastic, the plasticity of the white-coat mix must be derived primarily from the lime. But different limes have different degrees of plasticity. ${ }^{8}$

\section{(a) Putty From Quicklime}

Almost any kind of quicklime, when properly slaked with an excess of water, will produce a

\footnotetext{
"The Emley plastieimeter is the instrument in general use in the United States for measuring the plasticity of "finishing" limes to determine whether they meet the requirement that the plasticity figure of the putty shall he not less than $200[5,6$, and 7$]$.
}

putty of high plasticity. Prior to about 1900, lump quicklime was generally used to prepare putty for plastering, and it was the practice to age the putty for at least 2 weeks before use. ${ }^{9}$ More recently, whenever quicklime is used, it is generally of the pulverized type, which was introduced to facilitate slaking and to obtain complete hydration in a shorter time. ${ }^{10}$

The slaking of quicklime directly to a putty in large batches is conducive to complete hydration because of the prescnce of an excess of water, the boiling temperature attained, and the slow rate of cooling. Laboratory studies, made at the Bureau, of the hydration of dolomitic lime putties at different temperatures [2] indicated that even the $\mathrm{MgO}$ would be hydrated under these conditions. A subsequent study of the progress of hydration of $\mathrm{MgO}$ in a large batch of putty prepared by slaking pulverized dolomitic quicklime on the job showed that the $\mathrm{MgO}$ had become completely hydrated by the time the putty had cooled to room temperature.

The importance of the completeness of hydration will be recognized when it is realized that the surveys revealed no failure of the type heretofore described whenever the lime putty of the white coat had been prepared by slaking quicklime on the job.

\section{(b) Putty From Hydrated Lime}

Lime putty is made from hydrated lime simply by adding water, but not all hydrated limes will produce a plastic putty. Many quicklimes that will themselves produce a putty of great plasticity will not yield a dry, hydrated lime possessing highly plastic properties. At the time the present investigation was undertaken, hydrated limes were divided rather sharply into two classes on the basis of their plasticity: (1) the "finishing" hydrated limes made from a dolomitic limestone peculiar to a small district in northwestern Ohio, and (2) all other hydrates. Plasterers were quick to discovel the difference between the two classes of hydrates. 'The result was that putty made from either quicklime or Ohio finishing hydrate was specified to be mixed with the gypsum gaging plaster in the preparation of the white coat, with the tendency very strongly in favor of the hydrate because of its greater convenience.

Manufacturers of finishing hydrated lime almost invariably recommended that the putty be used only following a 12- to 24-hour soaking period. An erroneous belief seemed to be prevalent that such a soaking period was sufficient to provide a plastic putty and at the same time hydrate the product completely. The manufacturers of finishing hydrated lime were disposed to disclaim any responsibility for subsequent trouble if it could be proved that their directions

\footnotetext{
- Directions for slaking lump quicklime and for screening and aging the putty are given in Standard Specifieations for Gypsum Plastering issued hy the American Standards Association A42.1-1946 [24]. - See also, ASTM C5-26, Appendix.

10 Directions for slaking pulverized quicklime are also included in A42.1-194f.
} 
as to the time of this soaking period had not been followed.

Actually, however, the 12- to 24-hour soaking period hydrates but little of the large percentage of unhydrated $\mathrm{MgO}$ in regularly hydrated dolomitic lime. Wells and Taylor [2] showed that for six regularly hydrated dolomitic limes the average quantity of $\mathrm{MgO}$ hydrated at the end of the customary 1 day of soaking as a putty was only 19.1 percent. A more recent study of the progress of hydration of 18 such limes as putties [25] revealed that after soaking for 1 day, the average percentage of hydration of the $\mathrm{MgO}$ was 22.6 percent, in fairly close agreement with the average value of Wells and Taylor. At 3 and 7 days, the percentage hydration for the 18 hydrates increased to 29.2 and 41.0, respectively, in closer agreement with the 30.2 and 40.9 percent found by Wells and Taylor. Thus it can be seen that, roughly, but 20,30 , and 40 percent of the $\mathrm{MgO}$ in regularly hydrated dolomitic lime is hydrated at the end of the soaking periods of 1,3 , and 7 days, respectively. Inasmuch as most white coats are applied when the hydrates are soaked as putties within these time periods (usually 1 day), it is evident that the bulk of the $\mathrm{MgO}$ is still unhydrated at the time the white coats are applied. Although a small additional percentage of $\mathrm{MgO}$ may be hydrated while the white coat is setting, moist, and plastic, it cannot be great in view of the fact that it requires 3 to 5 months or more [25] to hydrate the $\mathrm{MgO}$ completely at room temperature, even as a wet putty.

\section{Application of the White Coat}

Generally the white coat is mixed by hand. When ready to apply, some of the putty is circled out on a mixing board. The circular space surrounded by the putty is then filled with water to about one-third its depth, the desired amount of retarder is mixed in the water, and the calcined gypsum is sifted into the water. After the water has wetted the calcined gypsum, the putty and gypsum are mixed thoroughly with a trowel and applied immediately over a base coat which has set and is surface-dry. The mix should be scratched in thoroughly, laid on well, doubled back, and filled out to a true even surface. The thickness should be from $1 / 16$ to $1 / 8$ inch. The finish should then be allowed to "draw" for a few minutes. At a certain stage, the glaze caused by the water on the surface will suddenly disappear and the surface will become dull, as the gypsum begins to set. The chemical reaction at this stage is

$$
\underset{\text { (Calcined gypsum) }}{\mathrm{CaSO}_{4} \cdot 1 / 2 \mathrm{H}_{2} \mathrm{O}}+\underset{\text { (water) }}{1 \mathrm{1} / 2 \mathrm{H}_{2} \mathrm{O}} \rightarrow \underset{\text { (gy psum) }}{\mathrm{CaSO}_{4}} \cdot 2 \mathrm{H}_{2} \mathrm{O}
$$

This is the proper time to trowel the finish. The plasterer brushes the surface with water, holding the brush in one hand and the trowel in the other so that the trowel may follow the brush immediately. It is essential that the plasterer use all the pressure he can apply to the trowel during this operation, and that the whole surface be gone over as rapidly as possible, without interruption.

As the finish-coat mix is composed largely of lime putty, there is a decided tendency for this coat to shrink and crack. This tendency can be overcome in two ways-by making the coat as thin as possible and by troweling it at exactly the proper time. A thin coat contains less volume than a thick coat and permits troweling with greater facility. With a thin coat the cracks can be closed, or rather prevented, by troweling just as the cementitious material is setting and hardening. If it is troweled before set has occurred, the plaster will continue to shrink (and crack) after the troweling. It cannot be troweled after set has occurred, for the material is then too rigid to yield to the trowel.

\section{Chemical Constituents of Freshly Set White-Coat Plaster}

The principal constituents of freshly set whitecoat finish are (1) gypsum $\left(\mathrm{CaSO}_{4} \cdot 2 \mathrm{H}_{2} \mathrm{O}\right)$, formed from the hemihydrate during the application of the white coat, and (2) the constituents of the lime putty. If a high-calcium lime has been used, $\mathrm{Ca}(\mathrm{OH})_{2}$ will be the only other main constituent. But if a regularly hydrated domolitic lime has been used, the principal constituents other than $\mathrm{CaSO}_{4} \cdot 2 \mathrm{H}_{2} \mathrm{O}$ will be not only $\mathrm{Ca}(\mathrm{OH})_{2}$, but also some $\mathrm{Mg}(\mathrm{OH})_{2}$ and considerable $\mathrm{MgO}$. A small quantity of anhydrite $\left(\mathrm{CaSO}_{4}\right)$ in the gaging plaster and impurities, such as $\mathrm{SiO}_{2}, \mathrm{Al}_{2} \mathrm{O}_{3}$, and $\mathrm{Fe}_{2} \mathrm{O}_{3}$, which occur in both the lime and the gaging plaster, will be in the white-coat plaster, regardless of the kind of lime used. In addition, there will be a small quantity of calcium carbonate, $\mathrm{CaCO}_{3}$; that originally present as core, that formed in the lime putty during soaking, and that occurring as an impurity in the gaging plaster.

\section{Drying and Carbonation of the White Coat}

After the plasterer has completed his work, the plaster will normally be exposed to air that is above freezing and is not saturated with moisture. Water immediately starts to evaporate from the plaster. The amount of water that will evaporate in a given time depends not only on the temperature and relative humidity of the air, but also on the quantity of air coming in contact with the plaster-that is, the circulation. The amount of water that must be evaporated will depend upon the amount put into the plaster and the amount either used up or liberated by the chemical reactions involved in the setting and hardening processes. During the hardening of a white-coat plaster, the conversion of the hemihydrate to gypsum uses up nearly half of the mixing water.

Additional hardening takes place as the constituents of the lime putty combine with the carbon dioxide of the air. 'This hardening, however, differs from that resulting in the conversion of hemihydrate to gypsum in that no water is actually used in this process. Not only the free water con- 
tained in the lime putty must be evaporated, but even that which is chemically combined with the lime will be replaced by carbon dioxide $\left(\mathrm{Ca}(\mathrm{OH})_{2}+\right.$ $\mathrm{CO}_{2} \rightarrow \mathrm{CaCO}_{3}+\mathrm{H}_{2} \mathrm{O}$ ) and evaporated as the hardening continues. A peculiarity of this reaction is, that it will not occur unless there is a small amount of water present, so that the lime will not continue to harden properly under excessively dry conditions. On the other hand, the presence of too much water will also prevent the proper carbonation of $\mathrm{Ca}(\mathrm{OH})_{2}$.

Inasmuch as the combination of $\mathrm{Ca}(\mathrm{OH})_{2}$ with $\mathrm{CO}_{2}$ from the air, to form $\mathrm{CaCO}_{3}$, proceeds slowly in normally dry plaster, but more rapidly when the optimum amount of moisture is present, it can be predicted that the extent of carbonation will vary greatly.

\section{Chemical Reactions Involving Volume Changes}

To determine which of the reactions is the most likely to cause expansion of the aged white coat, consideration will now be given to the volume changes involved in the chemical reactions of the setting and hardening of the white coat as well as in those occurring subsequently.

If the reactions involving increase in volume occur prior to the setting and liardening of a plaster, the danger of subsequent expansion from this source is eliminated. On the other hand, if these reactions occur after the plaster has hardened the likelihood of trouble ensuing because of volume change is greatly augmented. $\Lambda$ full consideration of the possibility of damaging expansion from chemical reaction therefore resolves itself into the study of not only those reactions that are attended by an increase in volume, but also of the magnitude of the volume change and whether the increase occurs before or after hardening.

The computed increases in net volume that may occur are given in table 2. Column 4 gives the molecular volume, obtained by dividing the molecular weight by the density. The percentage increase in volume is given in columns $5,6,7,8$, and 9 .

TABLE 2. Molecular weight, density, and molecular volume of compounds that may occur in white-coat plaster; and the calculated increases in volume in the formation of hydrates, carbonates, and sulfates

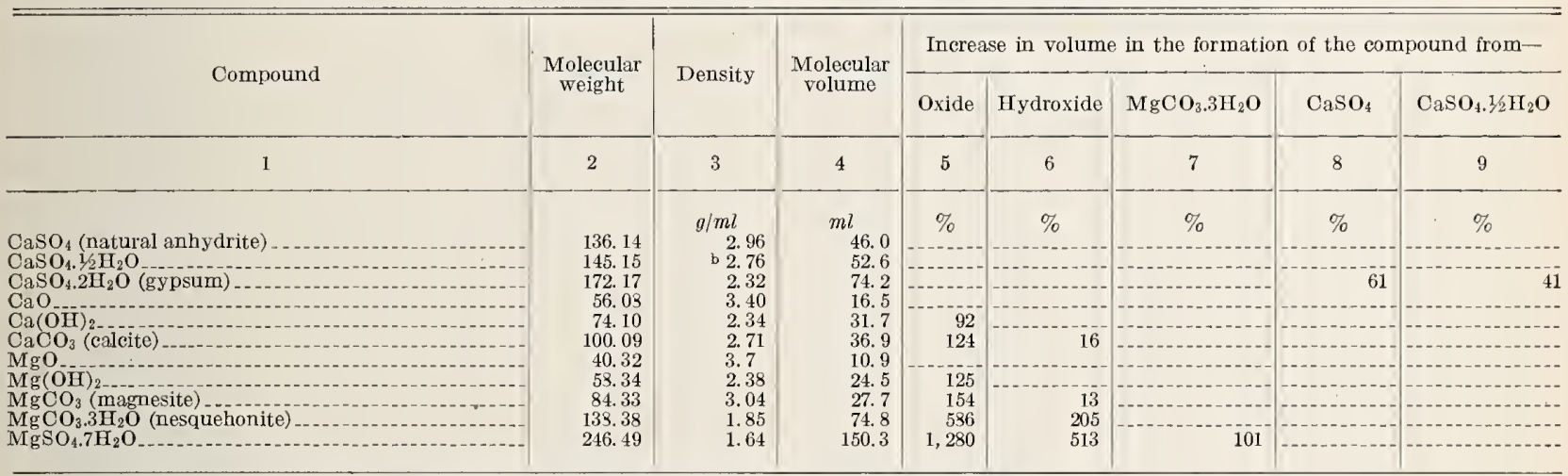

n Handhook of Chemistry and Physies. Chemical Rubber Publishing Co., Cleveland, Ohio (1939)

b J. H.van't Hoff, E. Armstrong, W. Hinrichsen, F. Weigert, and G. Just.' Z. phys. chem. 45, 272 (1903).

The first reactions to be considered will be those involving the constituents of the gaging plaster. It can be seen (column 9) that the computed net increase in volume of $\mathrm{CaSO}_{4} \cdot 1 / 2 \mathrm{H}_{2} \mathrm{O}$ to $\mathrm{CaSO}_{4} \cdot 2 \mathrm{H}_{2} \mathrm{O}$ is 41 percent. Inasmuch as the bulk of the hydration of $\mathrm{CaSO}_{4} \cdot 1 / 2 \mathrm{H}_{2} \mathrm{O}$ to $\mathrm{CaSO}_{4} \cdot 2 \mathrm{H}_{2} \mathrm{O}$ takes place during the setting process while the white coat is soft and plastic, the expansion is small, because the stresses set up by this increase are relieved. In fact, the setting process depends on the occurrence of this reaction. The small net expansion is of advantage to the plasterer as it occurs at a time when he is completing the troweling of the white coat and thus facilitates the closing of the cracks caused by the shrinkage of the lime. It is this expansion during setting that produces such excellent detail in plaster-of-paris casts. That the reaction does not proceed subsequent to the setting and hardening is amply demonstrated by the lack of any report of bulging of plaster-of-paris casts in the centuries during which plaster of paris has been used to produce cast objects.

As mentioned previously, some gaging plasters mav contain a small amount of anhydrous $\mathrm{CaSO}_{4}$, present either as natural anhydrite or formed in the calciners when gypsum is dehydrated beyond $\mathrm{CaSO}_{4} \cdot 1 / 2 \mathrm{H}_{2} \mathrm{O}$. Anhydrous $\mathrm{CaSO}_{4}$ can hydrate to $\mathrm{CaSO}_{4} .2 \mathrm{H}_{2} \mathrm{O}$ at room temperature. The computed net increase in volume is 61 percent (column 8). However, the amount of $\mathrm{CaSO}_{4}$ in gaging plaster is small, and if the $\mathrm{CaSO}_{4}$ is formed in the calciners, it hydrates readily. It, therefore, is converted to gypsum during the setting process. That the small quantity of natural anhydrite in the calcined gypsum is very unlikely to cause a damaging expansion after the white coat has set and hardened is also amply demonstrated by the lack of any report of subsequent expansion and bulging of plaster-of-paris casts.

Even with these very strong arguments against 
the possibility of $\mathrm{CaSO}_{4} \cdot \frac{1}{2} \mathrm{H}_{2} \mathrm{O}$ or $\mathrm{CaSO}_{4}$ causing any trouble, the probability of the presence of these constituents in the hardened white coat should and will be given consideration in seeking the cause of white-coat trouble.

The hydration of both $\mathrm{CaO}$ and $\mathrm{MgO}$ is accompanied by marked expansion. Thus, it can be seen (column 5) that the hydration of $\mathrm{CaO}$ to $\mathrm{Ca}(\mathrm{OH})_{2}$ is accompanied by an increase in volume of 92 percent; and that of $\mathrm{MgO}$ to $\mathrm{Mg}(\mathrm{OH})_{2}$, by an increase of 125 percent. As stated previously, if the hydration occurs prior to the setting and hardening of the plaster, the danger of any subsequent expansion from these sources is eliminated. As calcium oxide reacts so rapidly with water to form calcium hydroxide that hydration is completed in a very short time, there appears to be little or no likelihood of any danger of expansion because of this reaction.

Magnesia, on the other hand, as has been pointed out, is very subject to overburning, does not hydrate rapidly, is present in large quantities in regularly hydrated dolomitic finishing limes, and is hydrated but little during the soaking period prior to application of the finish coat. Therefore, it is apparent that the probability of damaging expansion resulting from the subsequent hydration of the $\mathrm{MgO}$ is a factor of moment and must be given prime consideration.

The reactions of the carbon dioxide of the air with the constituents of lime are also accompanied by an increase in volume. It can be seen from table 2 that when $\mathrm{CaO}$ or $\mathrm{MgO}$ carbonates directly to calcite $\left(\mathrm{CaCO}_{3}\right)$ or magnesite $\left(\mathrm{MgCO}_{3}\right)$, respectively, there is a marked increase in volume. The increase in volume for $\mathrm{CaO}$ is 124 percent and for $\mathrm{MgO} 154$ percent. In the first place, it has been shown that there is little or no $\mathrm{CaO}$ in lime putties, and in the second place, the oxides are usually converted to the hydrates before carbonation occurs. The possibility of any damaging expansion occurring as a result of the direct carbonation of $\mathrm{CaO}$ to $\mathrm{CaCO}_{3}$ can, therefore, be dismissed. It has been suggested that if the $\mathrm{MgO}$ in the set and hardened white coat had carbonated rather than hydrated, there would have been no expansion. This is not true. The volume increase in the direct carbonation of $\mathrm{MgO}$ to magnesite is 154 percent, an increase that is greater than that accompanying hydration of $\mathrm{MgO}$ to $\mathrm{Mg}(\mathrm{OH})_{2}$, which is 125 percent. The carbonation of the hydrates to the normal carbonates is attended by only a small increase in volume; for $\mathrm{Ca}(\mathrm{OH})_{2}$ to calcite, it is 16 percent and for $\mathrm{Mg}(\mathrm{OH})_{2}$ to magnesite, but 13 percent.

It will be shown later that carbonation in a white coat, even in the case of $\mathrm{Ca}(\mathrm{OH})_{2}$, is far from complete and, in general, the carbonation of the $\mathrm{Mg}(\mathrm{OH})_{2}$ does not occur until the more easily carbonated $\mathrm{Ca}(\mathrm{OH})_{2}$ has been completely changed to $\mathrm{CaCO}_{3}$. These conditions require the presence of moisture. If carbonation then proceeds with the conversion of $\mathrm{Mg}(\mathrm{OH})_{2}$ to a carbonate, the hydrated mineral nesquehonite $\left(\mathrm{MgCO}_{3} .3 \mathrm{H}_{2} \mathrm{O}\right)$ is formed and not magnesite $\left(\mathrm{MgCO}_{3}\right)$. The conversion of $\mathrm{Mg}(\mathrm{OH})_{2}$ to $\mathrm{MgCO}_{3} \cdot 3 \mathrm{H}_{2} \mathrm{O}$ is accompanied by an increase in volume of 205 percent. The net increase of $\mathrm{MgO}$ to $\mathrm{MgCO}_{3} .3 \mathrm{H}_{2} \mathrm{O}$ through the hydroxide $\left(\mathrm{Mg}(\mathrm{OH})_{2}\right)$ is still larger-586 percent. Bishop [26] has shown that the somewhat soluble nesquehonite in turn reacts with gypsum, $\mathrm{CaSO}_{4} \cdot 2 \mathrm{H}_{2} \mathrm{O}$, to form less soluble $\mathrm{CaCO}_{3}$ and magnesium sulfate. The crystallization of $\mathrm{MgSO}_{4} .7 \mathrm{H}_{2} \mathrm{O}$ results in a further increase in volume: 101 percent over $\mathrm{MgCO}_{3} .3 \mathrm{H}_{2} \mathrm{O}, 513$ percent over $\mathrm{Mg}(\mathrm{OH})_{2}$, and 1,280 percent over $\mathrm{MgO}$. This results in marked efflorescence and eventually the complete disintegration of the white coat. It is most fortunate, therefore, that the $\mathrm{Ca}(\mathrm{OH})_{2}$ is not completely carbonated to $\mathrm{CaCO}_{3}$, and that little or no carbonation of the $\mathrm{Mg}(\mathrm{OH})_{2}$ takes place. However, plaster failure characterized by efflorescence and ultimate disintegration is not the subject of this paper; it has already been discussed by Bishop. It has been mentioned at this time to show the very great magnitude of the expansion when magnesia is hydrated, carbonated, and then converted to magnesium sulfate.

\section{Investigation of White-Coat-Plaster Samples Taken After Failure}

A large number of samples of failed white-coat plaster collected in the eastern half of the United States were assembled, and an intensive study of their constitution was undertaken.

\section{Chemical Analyses}

Any paint on the fragments of white-coat plaster was carefully removed, and representative samples were then ground in a mortar and placed in airtight containers.

Because a white coat may contain a small amount of free, or uncombined, water, samples were dried to remove this water and to determine its quantity. This drying temperature should be such that the free water is completely removed without decomposing hydrated compounds that may be present. In the usual chemical analysis a temperature of $105^{\circ}$ to $110^{\circ} \mathrm{C}\left(221^{\circ}\right.$ to $\left.230^{\circ} \mathrm{F}\right)$ is used for the determination of free, or uncombined, water. However, such a temperature for white-coat samples is too high because it results in a partial dehydration of gypsum. Consequently, the samples were dried at $45^{\circ} \mathrm{C}\left(113^{\circ}\right.$ $\mathrm{F})$, the temperature given in both the Federal Specifications [27] and those of the American Society for Testing Materials for drying prior to the analysis and testing of gypsum products [28].

It has been found that when gypsum is heated for 1 hour at $110^{\circ} \mathrm{C}\left(130^{\circ} \mathrm{F}\right)$ it is converted primarily to hemihydrate, $\mathrm{CaSO}_{4} \cdot 1_{2} \mathrm{H}_{2} \mathrm{O}$. There is always a possibility, however, that a portion of the hemihydrate formed may, in turn, be dehydrated to anhydrous calcium sulfate. The loss 
at $110^{\circ} \mathrm{C}\left(230^{\circ} \mathrm{F}\right)$ can, nevertheless, be uscd to obtain a fair approximation of the quantity of gypsum present. 'This holds truc provided other hydrated materials are not decomposed by this lieat treatment. 'The $\mathrm{Ca}(\mathrm{OH})_{2}$ and $\mathrm{Mg}(\mathrm{OH})_{2}$ are not decomposed to any significant extent w'ien leated to $110^{\circ} \mathrm{C}\left(230^{\circ} \mathrm{F}\right)$. Consequently, the loss on lieating for 1 hour at $110^{\circ} \mathrm{C}\left(230^{\circ} \mathrm{F}\right)$ was determined for many of thesc samples, and the $\mathrm{CaSO}_{4} \cdot 2 \mathrm{H}_{2} \mathrm{O}$ content of the white coat was calculated from this loss on the assumption that it represented the water cvolved in the reaction

$$
\mathrm{CaSO}_{4} \cdot 2 \mathrm{H}_{2} \mathrm{O} \rightarrow \mathrm{CaSO}_{4} \cdot \frac{1}{2} \mathrm{H}_{2} \mathrm{O}+1 \frac{1 / 2}{2} \mathrm{H}_{2} \mathrm{O} \text {. }
$$

It was found, however, to be difficult to obtain good checks by this mcthod, because the procedure only partially dehydrated $\mathrm{CaSO}_{4} \cdot 2 \mathrm{H}_{2} \mathrm{O}$.

It has also been found that when the gypsum is heated for 1 hour at $200^{\circ} \mathrm{C}\left(392^{\circ} \mathrm{F}\right)$ it is converted for the most part to anhydrous $\mathrm{CaSO}_{4}$. At this more elevated temperature there is, however, the added possibility that a small amount of $\mathrm{Mg}(\mathrm{OH})_{2}$ or $\mathrm{Ca}(\mathrm{OH})_{2}$ may be decomposed. Such a procedure, nevertheless, gives a better indication of the content of $\mathrm{CaSO}_{4} .2 \mathrm{H}_{2} \mathrm{O}$ in the set white coat than heating at $110^{\circ} \mathrm{C}\left(230^{\circ} \mathrm{F}\right)$. The loss on heating for 1 hour at $200^{\circ} \mathrm{C}\left(392^{\circ} \mathrm{F}\right)$ (column 2 , table 3 ) was determined for the bulk of the samples, and the $\mathrm{CaSO}_{4} \cdot 2 \mathrm{H}_{2} \mathrm{O}$ content (column 11) was calculated from this loss on the assumption that it represents the water evolved in the reaction

$$
\mathrm{CaSO}_{4} \cdot 2 \mathrm{H}_{2} \mathrm{O} \rightarrow \mathrm{CaSO}_{4}+2 \mathrm{H}_{2} \mathrm{O}
$$

As the decomposition pressure of calcium carbonate is $1 \mathrm{~atm}$ at $884^{\circ} \mathrm{C}\left(1,623^{\circ} \mathrm{F}\right)$, the samples were next ignited for 1 hour at a temperature ranging between $900^{\circ}$ and $925^{\circ} \mathrm{C}\left(1,652^{\circ}\right.$ and $\left.1,697^{\circ} \mathrm{F}\right)$. This ignition temperature converts the constituents of white coat to an anhydrous and a carbon-dioxide-free basis without dissociating the anhydrous $\mathrm{CaSO}_{4}$ to $\mathrm{CaO}+\mathrm{SO}_{3}$. The loss at $900^{\circ}$ to $925^{\circ} \mathrm{C}\left(1,652^{\circ}\right.$ to $\left.1,697^{\circ} \mathrm{F}\right)$ includes therefore, the sum of the carbon dioxide and water of hydration and is given in column 3.

Samples of the white coats were decomposcd with hydrochloric acid, and the carbon dioxide evolved was collected in a gas-absorbing train. The percentage of $\mathrm{CO}_{2}$ thus obtained is given in column 4. By subtracting this from the percentage of loss on ignition at $900^{\circ}$ to $925^{\circ} \mathrm{C}$ $\left(1,652^{\circ}\right.$ to $\left.1,697^{\circ} \mathrm{F}\right)$, one obtains the combined water of hydration in the whitc coat. This is recorded in column 5. Another sample of each white coat was then analyzed for $\mathrm{SiO}_{2}, \mathrm{R}_{2} \mathrm{O}_{3}$, $\mathrm{CaO}$, and $\mathrm{MgO}$. As the quantities of $\mathrm{SiO}_{2}$ and $\mathrm{R}_{2} \mathrm{O}_{3}\left(\mathrm{Fe}_{2} \mathrm{O}_{3}, \mathrm{Al}_{2} \mathrm{O}_{3}, \mathrm{TiO}_{2}, \mathrm{P}_{2} \mathrm{O}_{5}\right.$, etc.) were small in nearly all cases, only the combined percentage of $\mathrm{SiO}_{2}$ and $\mathrm{R}_{2} \mathrm{O}_{3}$ (column 6) is given. The percentages of $\mathrm{CaO}$ and $\mathrm{MgO}$ are given in columns 7 and 8 , respectively. The percentage of $\mathrm{SO}_{3}$, given in column 9, was detelmined on still another sample.
The percentage of calcium hydroxide was obtained directly by the glycerol-ammonium acetate method [29] for determining "free lime" iu portland cement. 'This method for determining uncombined $\mathrm{CaO}$ is also applicable for $\mathrm{Ca}(\mathrm{OH})_{2}$. Consequently, it can be used for determining $\mathrm{Ca}(\mathrm{OH})_{2}$ in white-coat samples, since it was found that $\mathrm{CaSO}_{4} .2 \mathrm{H}_{2} \mathrm{O}, \mathrm{CaCO}_{3}, \mathrm{Mg}(\mathrm{OHI})_{2}$, and $\mathrm{MgO}$ do not interfere with the determination. 'The possibility of any $\mathrm{CaO}$ being present in aged white coat is too remote to warrant consideration of any interference by $\mathrm{CaO}$. The rcaction of $\mathrm{Ca}(\mathrm{OH})_{2}$ with the glycerol-ammonium acetate solution is even slower than that of $\mathrm{CaO}$ ("frce lime") and, consequently, the sample must be boiled for some time after each addition of the titrating solution. When the crystals of calcium lyydroxide are coated with a film of calcium carbonate, the extraction is still slower, and it is very difficult to determine when the reaction has reached completion. There is a tendency, therefore, to obtain values which may be slightly low with carbonated material. Nevertlieless, the percentages of $\mathrm{Ca}(\mathrm{OH})_{2}$ obtained by this direct method are given in column 10 .

\section{Computed Compound Composition}

On the assumption that the $\mathrm{SO}_{3}$ (column 9) is present as gypsum, the percentage of $\mathrm{CaSO}_{4} .2 \mathrm{H}_{2} \mathrm{O}$ is given in column 12. The percentage of $\mathrm{CaSO}_{4}$.$2 \mathrm{H}_{2} \mathrm{O}$ thus obtained can be compared with that calculated from the loss at $200^{\circ} \mathrm{C}\left(392^{\circ} \mathrm{F}\right.$ ) (column 11). The percentage of $\mathrm{CaSO}_{4} \cdot 2 \mathrm{H}_{2} \mathrm{O}$ cannot be higher than that calculated in column 12 , which is based on the percentage of $\mathrm{SO}_{3}$. It can, however, be lower if some of the $\mathrm{SO}_{3}$ is present as natural anhydrite $\left(\mathrm{CaSO}_{4}\right)$, but only slightly lower, because the quantity of natural anhydrite in gaging plaster is generally small.

It was assumed that the $\mathrm{CO}_{2}$ was combined with the $\mathrm{CaO}$ as calcium carbonate, and the percentage of $\mathrm{CaCO}_{3}$ calculated from the $\mathrm{CO}_{2}$ (column 4) is given in column 13. Although some of the carbon dioxide may have been combined with the $\mathrm{MgO}$, it seems probable that it was almost entirely combined with the calcium oxide, as the latter is much more active, and as calcium carbonate has a higher dissociation temperature than magnesium carbonate.

The $\mathrm{CaO}$ other than that calculated to be combined as $\mathrm{CaSO}_{4} \cdot 2 \mathrm{H}_{2} \mathrm{O}$ (column 12) and $\mathrm{CaCO}_{3}$ (column 13), was assumed to be present as $\mathrm{Ca}(\mathrm{OH})_{2}$ and the calculated percentage is given in column 14. If the assumptions up to this point are correct, then the pcrcentage of $\mathrm{Ca}(\mathrm{OH})_{2}$ obtained directly by the glycerol-ammonium acetate method (column 10) should agree with that computed from the chemical analyses (column 14). This would be true, since, as stated previously, $\mathrm{CaSO}_{4}$.$2 \mathrm{H}_{2} \mathrm{O}, \mathrm{CaCO}_{3}, \mathrm{Mg}(\mathrm{OH})_{2}$, and $\mathrm{MgO}$ do not interfcrc with the direct determination of $\mathrm{Ca}(\mathrm{OH})_{2}$. Considering the tendency of the glycerol-ammonium acetate method to give a slightly low value, the percentage of $\mathrm{Ca}(\mathrm{OH})_{2}$ obtained by the direct 


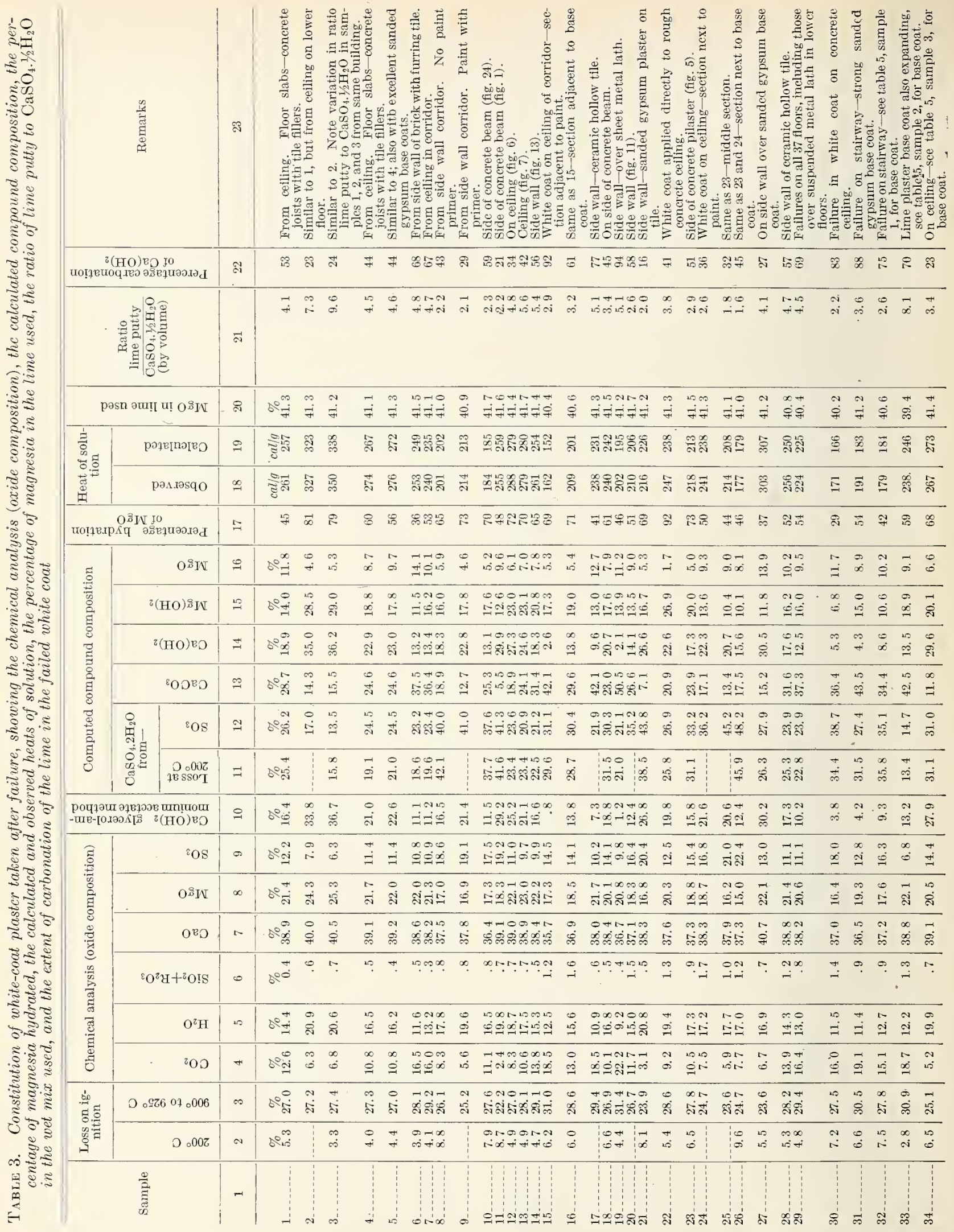




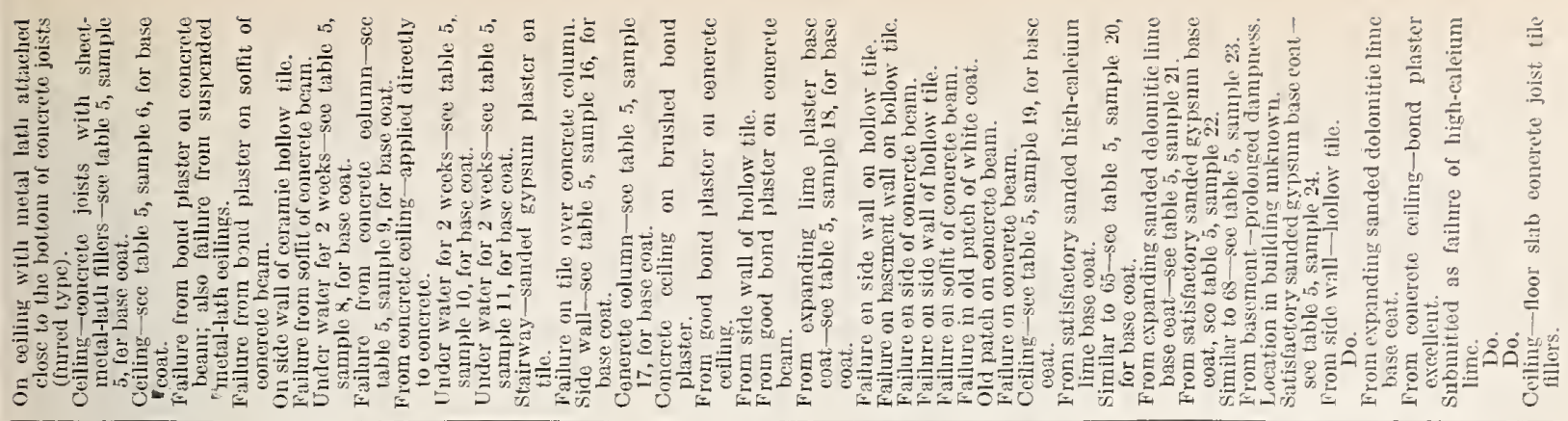

Б ప

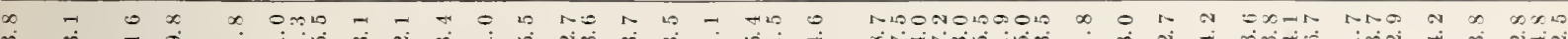

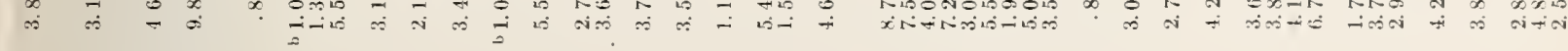

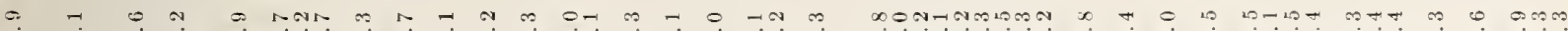

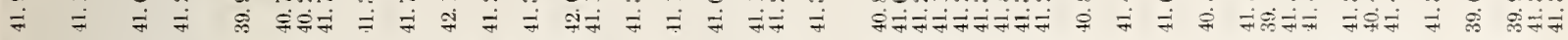

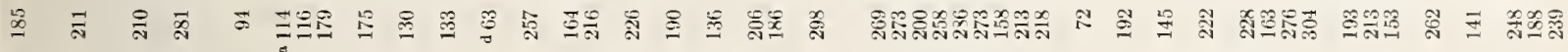
央 总 9 盾

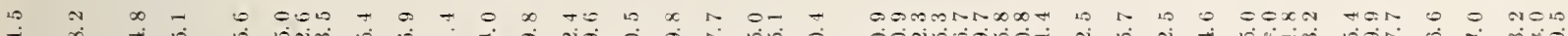

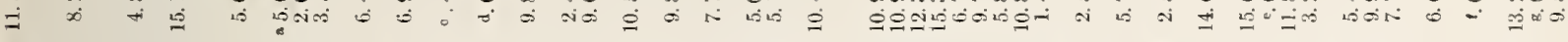

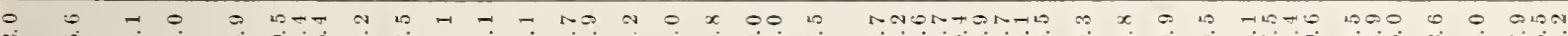
จ

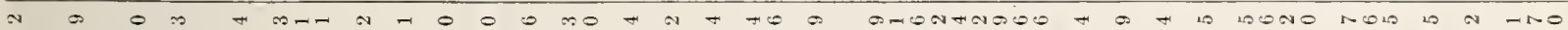

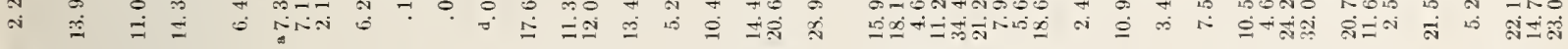

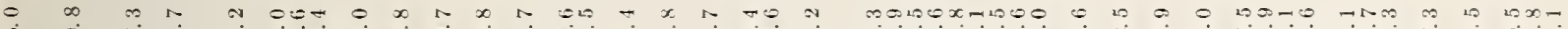

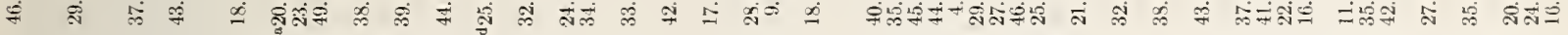

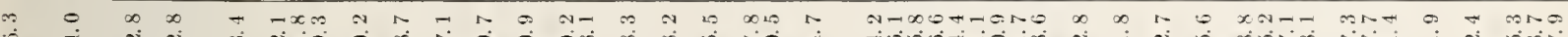

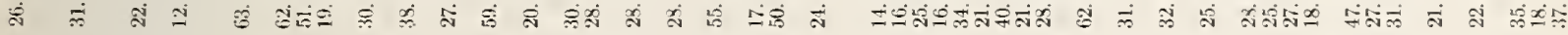

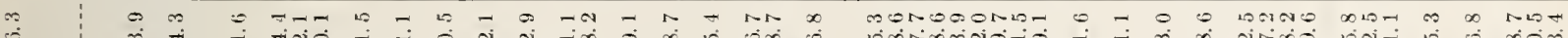
ชิ

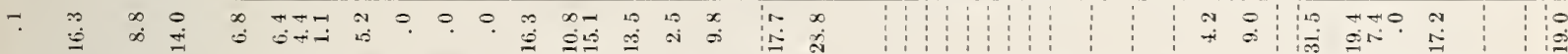

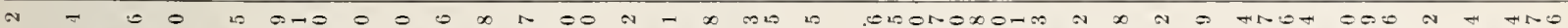

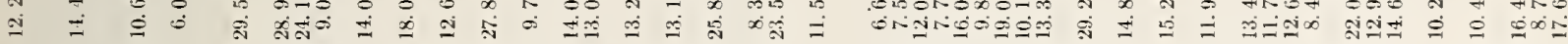

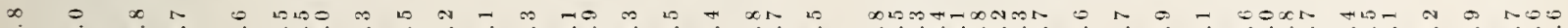

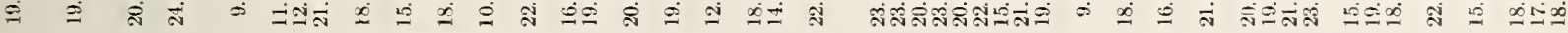

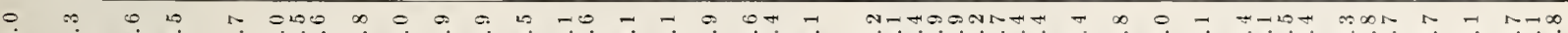

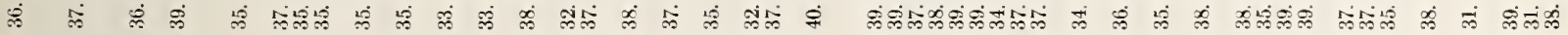

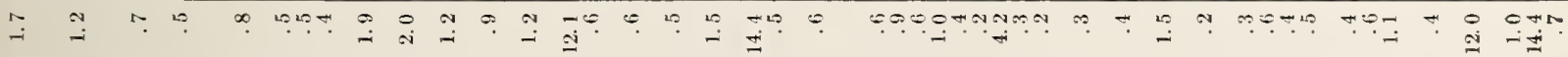

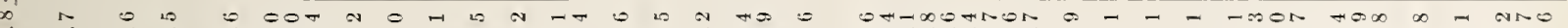

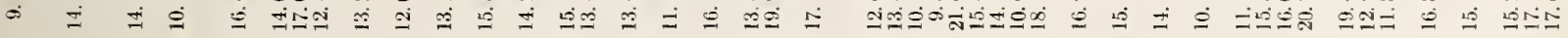

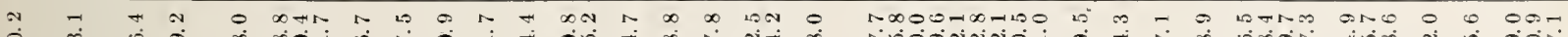
வิ

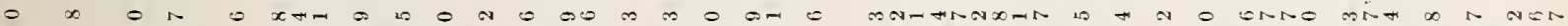

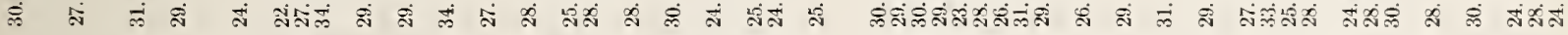

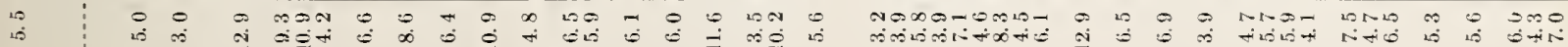




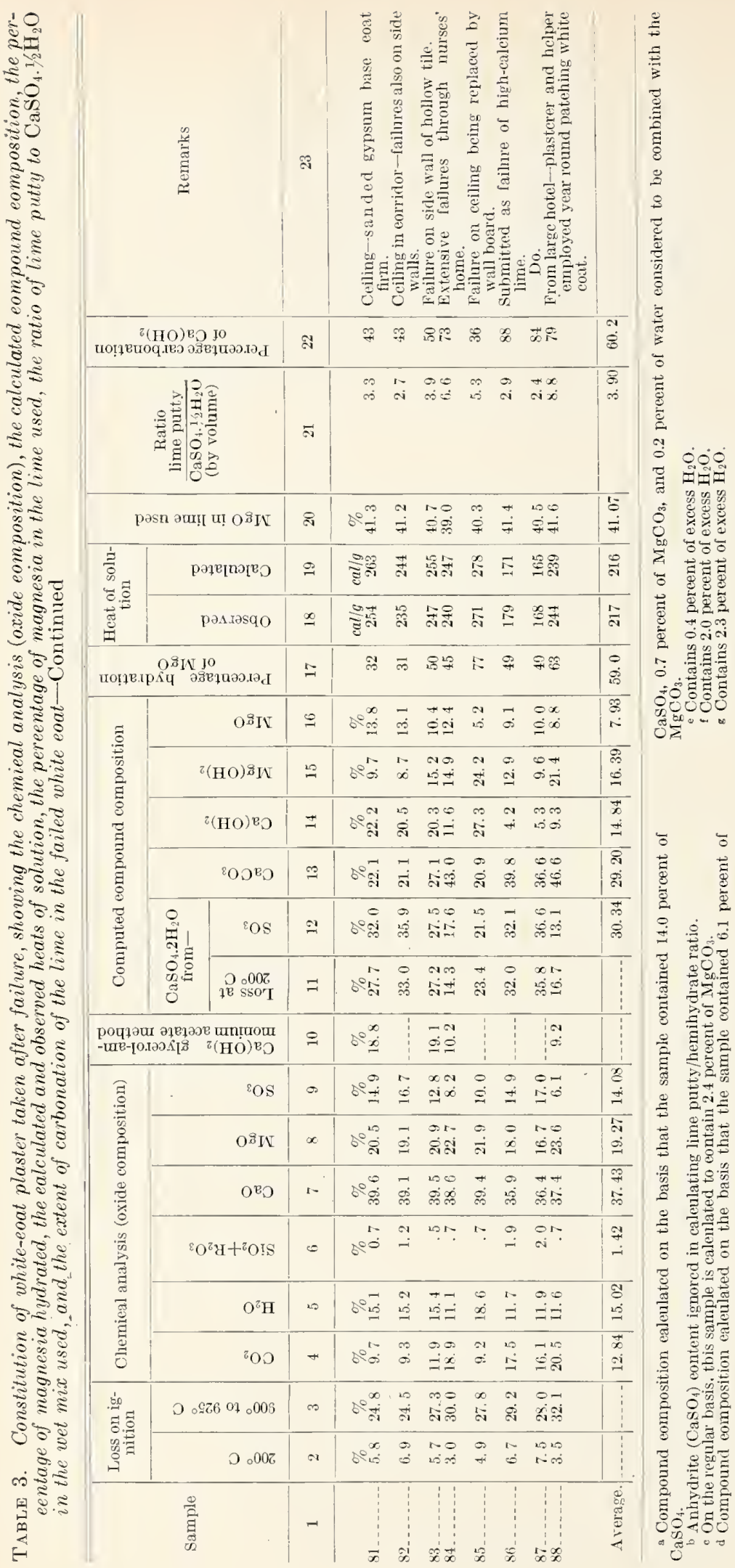


method agrees woll with the computed value. If the magnesia had carbonated to any appreciable extent, the calculated percentage of $\mathrm{Ca}(\mathrm{OH})_{2}$ would be much higher, and this good agreoment would no longer prevail. The close agrecment is therefore added proof that there is normally little or no magnesium carbonate present in aged whitecoat samples.

It should be emphasized that all of the samples of defective white coat contained from 9.6 to 25.3 percent of magnesia (see column 8). In other words, it seems clear that all of these samples of bu:Iging plaster were made from mixtures of dolomitic lime and plaster of paris.

The quantity of water that remained unaccounted for after calculating that required by the $\mathrm{CaSO}_{4} \cdot 2 \mathrm{H}_{2} \mathrm{O}$ and $\mathrm{Ca}(\mathrm{OH})_{2}$ was assumed to be combined as magnesium hydroxide, and the calculated percentage of $\mathrm{Mg}(\mathrm{OH})_{2}$ is given in column 15. Rarely was there sufficient water to combine with all of the magnesia as given in column 8. Consequently, in nearly every case, there was some free or uncombined $\mathrm{MgO}$; its pereentage is given in column 16 . On whatever basis the computations are made, it will be found that there was seldom enough $\mathrm{H}_{2} \mathrm{O}$ present to hydrate completely all of the magnesia, even assuming that the $\mathrm{SO}_{3}$ was present as $\mathrm{CaSO}_{4} \cdot{ }_{2}^{1} \mathrm{H}_{2} \mathrm{O}$ rather than gypsum, $\mathrm{CaSO}_{4} \cdot 2 \mathrm{H}_{2} \mathrm{O}$. Such an assumption, however, is entirely without justification, considering (1) that rapid conversion of $\mathrm{CaSO}_{4} \cdot 1 / 2 \mathrm{H}_{2} \mathrm{O}$ to $\mathrm{CaSO}_{4} \cdot 2 \mathrm{H}_{2} \mathrm{O}$ is an essential feature in the initial setting of white coat, and (2) that there is an approximate agreement between the contents of $\mathrm{CaSO}_{4} \cdot 2 \mathrm{H}_{2} \mathrm{O}$ given in columns 11 and 12 .

It should be noted that no consideration has been given to the small pereentage of $\mathrm{SiO}_{2}$ plus $\mathrm{R}_{2} \mathrm{O}_{3}$, shown in column 6. Although the $\mathrm{SiO}_{2}$ and $\mathrm{R}_{2} \mathrm{O}_{3}$ may have been present in part as calcium silicates, aluminates, or ferrites, the percentages of the various constituents were calculated by ignoring them. It should be noted that in a few instances the $\mathrm{SiO}_{2}$ plus $\mathrm{R}_{2} \mathrm{O}_{3}$ was slightly over 1 perecnt. Generally the silica in these instances was prescnt as grains of quartz and no doubt consisted of particles of sand that had been troweled into the white coat.

To summarize, then, in this method of calculating the compound composition of the white coat, it was assumed that the $\mathrm{SO}_{3}$ was present as gypsum, $\mathrm{CaSO}_{4} \cdot 2 \mathrm{H}_{2} \mathrm{O}$; the $\mathrm{CO}_{2}$, as $\mathrm{CaCO}_{3}$; and the lime in excess of that combined as $\mathrm{CaSO}_{4} .2 \mathrm{H}_{2} \mathrm{O}$ and $\mathrm{CaCO}_{3}$, as $\mathrm{Ca}(\mathrm{OH})_{2}$. 'The $\mathrm{H}_{2} \mathrm{O}$, other than that combined in the gypsum and calcium hydroxide, was assumed to be present in $\mathrm{Mg}(\mathrm{OH})_{2}$ and the magnesia in cxcess of magnesium hydroxide, as $\mathrm{MgO}$. In $1922 \mathrm{~J}$. W. McBurney made similar assumptions in his study of the plaster failures at Mt. Sinai Hospital, Cleveland, Ohio.

\section{Differential Thermal Analyses}

The results of differential thermal analyses verify the assumptions made in calculating the constitution of the white-coat plasters. In figure 18 are shown the heating curves of four mixtures of $\mathrm{CaSO}_{4} .2 \mathrm{H}_{2} \mathrm{O}, \mathrm{Mg}(\mathrm{OH})_{2}, \mathrm{MgO}, \mathrm{Ca}(\mathrm{OH})_{2}$, and $\mathrm{CaCO}_{3}$. These mixtures were prepared to represent the composition of white-coat plasters in various stages in the hydration of the $\mathrm{MgO}$. Beside each curve in figure 18 is shown the percentage of $\mathrm{Mg}(\mathrm{OH})_{2}$ contained in the sample, 27 percent representing complete hydration of the $\mathrm{MgO}$.

Five distinct regions of heat absorption are apparent on the curves. 'These absorptions, in the order of increasing temperature, are caused by (A) the dehydration of $\mathrm{CaSO}_{4} \cdot 2 \mathrm{H}_{2} \mathrm{O}$ to $\mathrm{CaSO}_{4}$.${ }_{1}^{1 / 2} \mathrm{H}_{2} \mathrm{O}$, (B) the dehydration of $\mathrm{CaSO}_{4} \cdot \frac{1}{2} \mathrm{H}_{2} \mathrm{O}$ to $\mathrm{CaSO}_{4}$, (C) the dehydration of $\mathrm{Mg}(\mathrm{OH})_{2}$ to $\mathrm{MgO}$, (D) the dehydration of $\mathrm{Ca}(\mathrm{OH})_{2}$ to $\mathrm{CaO}$, and, finally $(\mathrm{E})$ the decarbonation of $\mathrm{CaCO}_{3}$ to $\mathrm{CaO}$. These five reactions are represented on the heating curves (fig. 18) of all the samples containing $\mathrm{Mg}(\mathrm{OH})_{2}$.

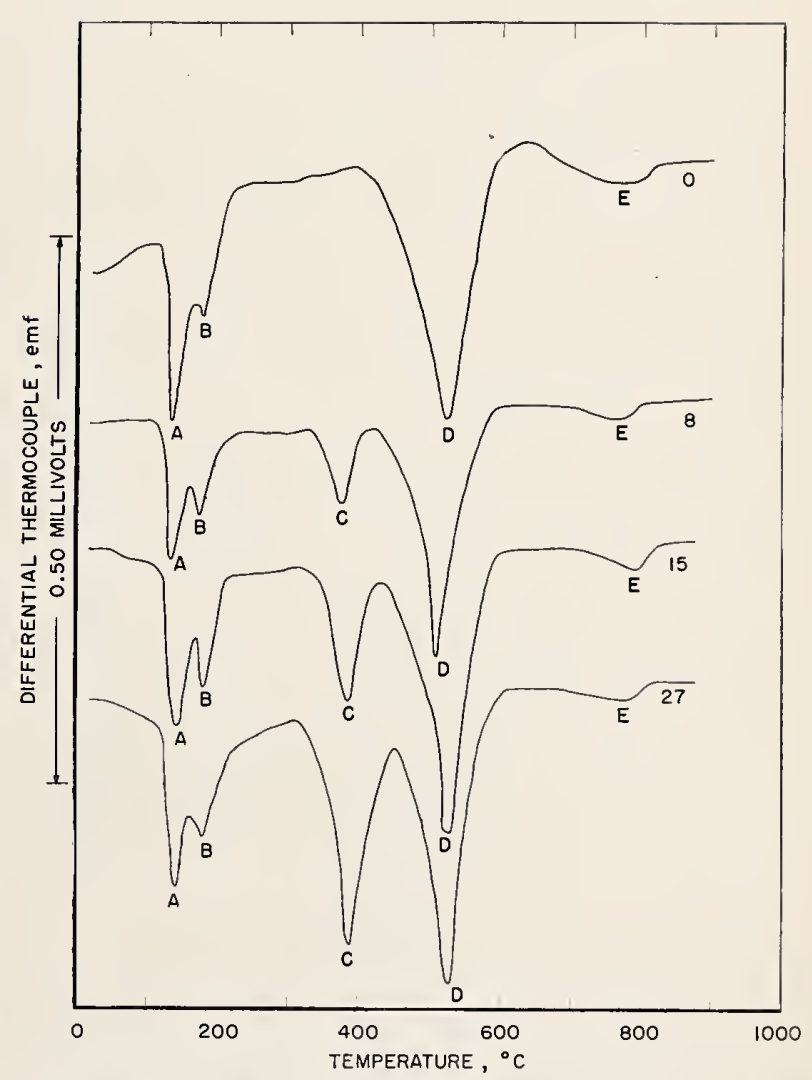

FIGURE 18. Differential heating curves of four mixtures of $\mathrm{CaSO}_{4} .2 \mathrm{H}_{2} \mathrm{O}, \mathrm{Mg}(\mathrm{OH})_{2}, \mathrm{MgO}, \mathrm{Ca}(\mathrm{OH})_{2}$, and $\mathrm{CaCO}_{3}$.

The perentage of $\mathrm{Mg}(\mathrm{OH})_{2}$ is indicated beside each curve. Fire regions of heat absorption, in the order of increasing temperature, are $\mathrm{A}$, debydration of gypsum to hemihydrate, $\mathrm{B}$, dehydration of hemih crate, $\mathrm{C}$, dehydration of magnesium hydroxide, $D$, dehydration of calcium lydroxide, and $E$, decomposition of calcium carbonate. 


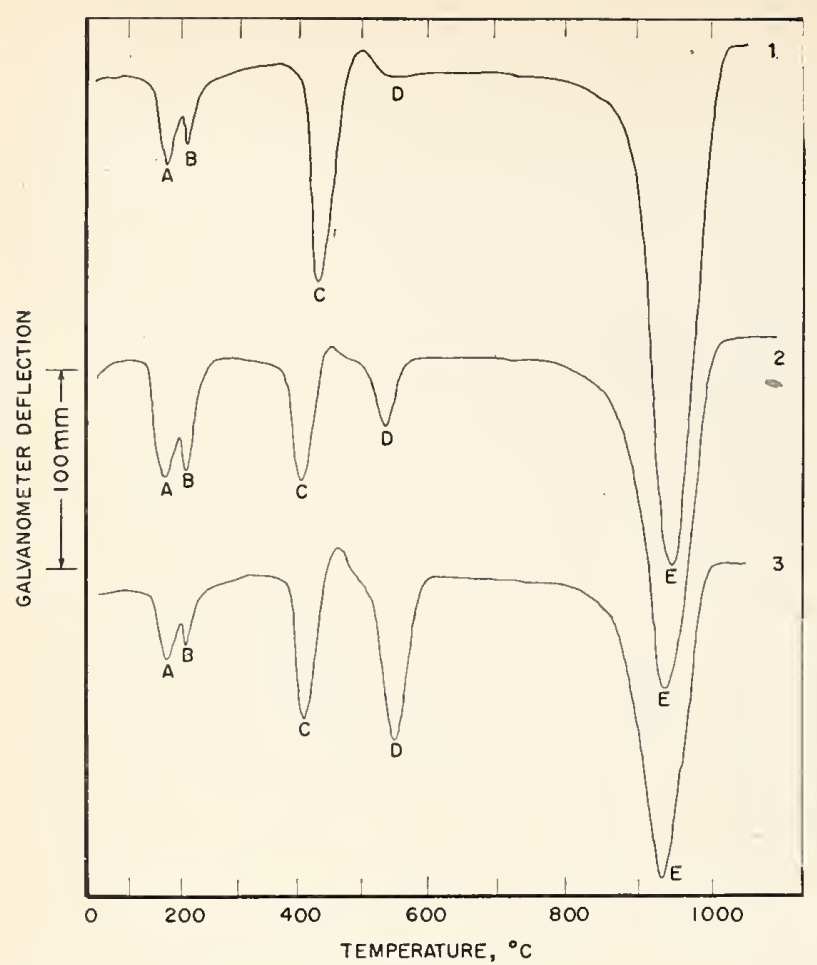

FIGURE 19. Differential heating curves of three samples of white-coat plaster that had failed by expansion.

The five major regions of heat absorption, in tho order of increasing tempcrature, are $\mathbf{A}$, dehydration of gypsum to hemihydrate, $B$, dehydration of hemihydrate, $C$, dehydration of magnesium hydroxide, $D$, dehydration of calcium hydroxide, and $\mathrm{E}$, decomposition of calcium carhonate.

The five major heat effects are shown on the heating curves of samples from three plaster failures, figure 19. Particularly to be noted is the almost complete absence in curve 1 of the deflection characteristic of the dehydration of $\mathrm{Ca}(\mathrm{OH})_{2}$. This sample, in which almost complete carbonation of $\mathrm{Ca}(\mathrm{OH})_{2}$ had occurred, contained no detectable magnesium carbonate. The composition of the plasters represented by the curves in figure 19 can be found in table 3 , where samples numbered 42,32 , and 6 correspond to curves 1, 2, and 3 , respectively. The areas of the magnesium-hydroxide deflections on the heating curves are roughly proportional to the calculated $\mathrm{Mg}(\mathrm{OH})_{2}$ in these plasters. It is apparent that the assumptions made in calculating the compound composition of the plasters must be approximately correct.

\section{Extent of Hydration of Magnesia in the Aged White Coat}

The percentage hydration of the total magnesia in the white coats is recorded in column 17 of table 3 . This percentage was calculated from the total amount of magnesia in the samples (column 8) and the percentage of unhydrated $\mathrm{MgO}$ (column 16). The average amount of hydration of the $\mathrm{MgO}$ in these plaster-failure samples is 59.0 percent, with a standard deviation of 17.2 percent and extreme values of 27 percent and 100 percent. This 59.0 percent is much in excess of the average of $19.1^{11}$ percent hydration found by Wells and Taylor [2] for six regularly hydrated dolomitic limes after the customary 1 day of soaking of the lime as a putty. It is also much in excess of the average of 22.6-percent hydration more recently obtained [25] for 18 additional samples of normally hydrated dolomitic lime at the end of the customary soaking of 1 day as a putty. In agreement with the contention of Newman [30], hydration of the magnesia must, therefore, have occurred on the wall.

\section{X-ray Analyses}

Although in many materials the presence of a suspected material can be shown by the X-ray pattern, the presence of $\mathrm{MgO}$ in hardened plaster is not easy to prove. In table 4 are given the interplanar spacings and estimated intensities of the lines of the X-ray patterns of three plaster samples. Also tabulated from the literature are the patterns of gypsum, plaster of paris, anhydrite, calcium hydroxide, calcium oxide, calcium carbonate, magnesium oxide, magnesium hydroxide, magnesium carbonate (magnesite), and nesquehonite $\left(\mathrm{MgCO}_{3} .3 \mathrm{H}_{2} \mathrm{O}\right)$. All these compounds must be considered potential constituents of a hardened plaster. Simplifying assumptions, such as have been made in this paper in connection with the chemical analyses, would eliminate plaster of paris, calcium oxide, and magnesite, but evidence has been observed of the presence of each of the other compounds in hardened plaster.

Many lines are identical in the patterns of two or more compounds as well as in the patterns of the hardened plasters. Study of the $\mathrm{X}$-ray spectrograms of mixtures of $\mathrm{CaCO}_{3}, \mathrm{Mg}(\mathrm{OH})_{2}, \mathrm{MgO}$, $\mathrm{Ca}(\mathrm{OH})_{2}$, and $\mathrm{CaSO}_{4} \cdot 2 \mathrm{H}_{2} \mathrm{O}$ has led to the conclusion that not less than 5 percent of $\mathrm{Mg}(\mathrm{OH})_{2}$ must be present to permit its detection by means of X-rays. The detection of $\mathrm{MgO}$ is less easy as the strong lines of $\mathrm{MgO}$ coincide with moderately strong lines of other constituents of hardened plaster. The presence of $\mathrm{MgO}$ must be established by intercomparison with other lines of the interfering substance. It is probable that not less than 10 percent of $\mathrm{MgO}$ must occur in a sample of hardened plaster for its presence to be established with certainty. This quantity, 10 percent, is more than half the average amount of total $\mathrm{MgO}$ present in all forms in hardened plaster, as shown by the chemical analyses in table 3 .

\section{Heat of Solution}

It was shown by Wells and Taylor [2] that the analytical determination of the degree of hydration of magnesia in hydrated dolomitic limes and putties can be indirectly verified by means of heatof-solution determinations. It was decided,"there-

11 Erroneously reported hy Newman [30] as 12 percent, which is the a verage value of the percentage hydration of these commercial hydrated limes just prior to soaking them for 1 day as putties. 
TABLE 4. X-ray patterns of plasters and of potential constituents

[Data for compounds from "X-ray diffraction data cards," American Society for Testing Materials, Philadelphia, Pa., 1915]

\begin{tabular}{|c|c|c|c|c|c|c|c|c|c|c|c|c|c|c|c|c|c|c|c|c|c|c|c|c|c|}
\hline \multicolumn{2}{|c|}{ Sample $\mathbf{F}$} & \multicolumn{2}{|c|}{ Sample D } & \multicolumn{2}{|c|}{ Sample B } & \multicolumn{2}{|c|}{$\begin{array}{l}\mathrm{CaSO}_{4 \cdot-} \\
2 \mathrm{H}_{2} \mathrm{O}\end{array}$} & \multicolumn{2}{|c|}{$\mathrm{Ca}(\mathrm{OH})_{2}$} & \multicolumn{2}{|c|}{$\mathrm{CaCO}_{3}$} & \multicolumn{2}{|c|}{$\mathrm{MgO}$} & \multicolumn{2}{|c|}{$\mathrm{Mg}(\mathrm{OH})_{2}$} & \multicolumn{2}{|c|}{$\underset{3 \leqslant \mathrm{H}_{2} \mathrm{O}}{\mathrm{CaSO}_{4} \cdot-}$} & \multicolumn{2}{|c|}{$\mathrm{CaO}$} & \multicolumn{2}{|c|}{$\mathrm{CaSO}_{4}$} & $\begin{array}{l}\mathrm{MgC} \\
3 \mathrm{H}\end{array}$ & $\begin{array}{l}\mathrm{O}_{3} \mathrm{O}^{3-} \\
\mathrm{O}^{-}\end{array}$ & $\mathrm{MgC}$ & $\mathrm{CO}_{3}$ \\
\hline 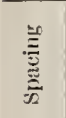 & $\stackrel{\overrightarrow{\bar{\Xi}}}{\vec{\Xi}}$ & 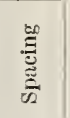 & 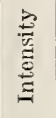 & 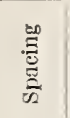 & 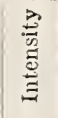 & 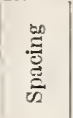 & $\begin{array}{l}\stackrel{5}{\frac{5}{5}} \\
\stackrel{\Xi}{\Xi}\end{array}$ & 总 & 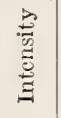 & 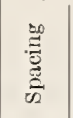 & 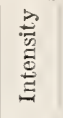 & 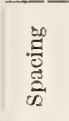 & 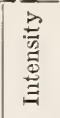 & 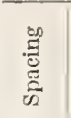 & 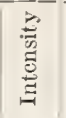 & 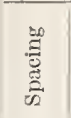 & 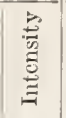 & 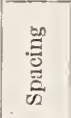 & 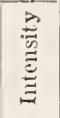 & 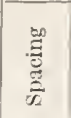 & 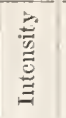 & 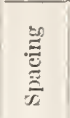 & 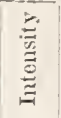 & 䒿 & 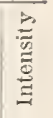 \\
\hline-4.5 & $\mathrm{VW}$ & ${ }_{7.45}^{A}$ & MI & A & & $\underset{7.70}{A}$ & $\begin{array}{l}\mathrm{I} / \mathrm{I}_{l} \\
0.50\end{array}$ & A & $\Gamma / I_{l}$ & A & $I / I_{l}$ & A & {$\left[/ \Gamma_{l}\right.$} & A & $\mathrm{I} / \mathrm{I}_{l}$ & $\begin{array}{r}\mathrm{A} \\
6.0\end{array}$ & $\begin{array}{l}\mathrm{I} / \mathrm{I}_{z} \\
0.40\end{array}$ & A & $I / \Gamma_{l}$ & $A$ & $\mathrm{I} / \mathrm{I}_{t}$ & $6 . \bar{A}$ & $\begin{array}{l}\mathrm{I} / \mathrm{I}_{l} \\
1.00\end{array}$ & $A$ & $I / I_{l}$ \\
\hline 4. 75 & rs & 4.80 & $M$ & & & & & 4. 93 & 0.50 & & & & & 4.75 & 0.53 & & & & & & & 5.8 & .08 & & (n) \\
\hline $\begin{array}{l}4.23 \\
3.82\end{array}$ & $\underset{V W}{M I}$ & $\begin{array}{l}\text { 4. } 21 \\
3.76\end{array}$ & $\begin{array}{l}\text { MI } \\
\text { W }\end{array}$ & $\begin{array}{l}4.09 \\
3.81\end{array}$ & $\underset{\text { VI }}{\text { MI }}$ & $\begin{array}{l}4.29 \\
3.81\end{array}$ & $\begin{array}{r}1.00 \\
.15\end{array}$ & & & 3.86 & 0.08 & & & & & & & & & & & 4. 96 & $\begin{array}{l}.08 \\
80\end{array}$ & & $\ldots$ \\
\hline & & $\begin{array}{l}3.60 \\
3.42\end{array}$ & $\mathrm{VW}$ & & & 3.81 & .15 & & & 3.00 & 0.00 & & & & & 3.48 & .30 & & & $\begin{array}{l}3.88 \\
3.49\end{array}$ & $\begin{array}{l}0.0 .3 \\
1.00\end{array}$ & $\begin{array}{l}3.86 \\
3.58\end{array}$ & $\begin{array}{l}.80 \\
.16\end{array}$ & & $-\cdots$ \\
\hline & & & & $\begin{array}{l}3.27 \\
3.00\end{array}$ & MI & & & 3.11 & .25 & & & & & & & & & & & 3.11 & .03 & 3.23 & .16 & & \\
\hline $\begin{array}{l}3.01 \\
2.85\end{array}$ & $\begin{array}{c}\mathrm{S} \\
\mathrm{vW}\end{array}$ & $\begin{array}{l}3.00 \\
2.84\end{array}$ & IV & $\begin{array}{l}3.00 \\
2.82\end{array}$ & Vw & $\begin{array}{l}3.06 \\
2.87\end{array}$ & $\begin{array}{l}.63 \\
.63\end{array}$ & & & 3.04 & 1.00 & & & & & $\begin{array}{l}3.00 \\
2.80\end{array}$ & $\begin{array}{l}.60 \\
1.00\end{array}$ & & & 2.85 & .67 & $\begin{array}{l}3.02 \\
2.77\end{array}$ & $\begin{array}{l}.21 \\
.16\end{array}$ & & .... \\
\hline 2.59 & $\mathrm{VS}$ & 2. 66 & MI & 2. 60 & $1 \mathrm{~T}$ & 2.68 & .50 & & & & & & & & & & & 2.76 & 0.40 & & & & & 2.74 & 1.0 \\
\hline & & 2.60 & $\mu_{1}$ & & . & .... & $\cdots$ & 2.63 & 1.00 & & $\cdots$ & & & & & & & ...... & & $\cdots$ & .... & 2.61 & .48 & - n & $-\cdot$ \\
\hline 2.50 & $1 \pi$ & 2.47 & W & 2.48 & M & 2.48 & .20 & & 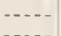 & 2.49 & .20 & 42 & 0.06 & & & & & & & 2. 46 & .07 & 2.51 & .40 & 2.50 & .2 \\
\hline $\begin{array}{l}2.35 \\
2.26\end{array}$ & MI & $\begin{array}{l}2.35 \\
2.36\end{array}$ & $M$ & $\begin{array}{l}2.37 \\
2.26\end{array}$ & VW & & & & & & & & - & 2.35 & 1.00 & 2.34 & .02 & 2. 39 & 1.00 & 2. 32 & .33 & 2.35 & .05 & $\cdots$ & -.. \\
\hline 2.19 & W & 2.22 & $\mathrm{VW}$ & 20 & $N 1$ & 2.22 & .20 & & & 2.25 & $-2 t$ & & & & & & & & & $\begin{array}{l}2.26 \\
2.20\end{array}$ & .01 & 2.17 & .16 & 2.14 & 1 \\
\hline 2.09 & M & 2.08 & is & 2. 08 & $\underset{\mathrm{S}}{\mathrm{MI}}$ & 2.07 & .50 & & & 2. 09 & .20 & 2. 10 & 1.00 & & & 2. 13 & .18 & & & 2.08 & .11 & & & 2.10 & .8 \\
\hline $\begin{array}{l}1.913 \\
1.870\end{array}$ & w & $\begin{array}{l}1.915 \\
1.865\end{array}$ & iI & $\begin{array}{l}1.91 \\
1.87\end{array}$ & iI & 1.88 & .25 & 1.9 & .50 & $\begin{array}{l}1.92 \\
1.87\end{array}$ & $\begin{array}{l}.32 \\
.24\end{array}$ & & $\ldots$ & & & 1.85 & 60 & & & $\begin{array}{l}1.99 \\
1.93\end{array}$ & .11 & $\begin{array}{l}2.01 \\
1.92\end{array}$ & $\begin{array}{l}.08 \\
.32\end{array}$ & 1.93 & .4 \\
\hline 1.79 & $\frac{d}{\mathrm{~s}}$ & 1. 792 & $\mathrm{M}$ & 1.79 & W & 1.79 & .20 & 1.79 & .40 & & $\cdots$ & & $\cdots$ & 1.79 & .40 & & & & & 1. 86 & .27 & 1. 83 & .08 & & $\therefore$ \\
\hline $\begin{array}{l}1.74 \\
1.650\end{array}$ & iI & 1.683 & $M$ & 1.66 & $\mathrm{VW}$ & 1.66 & .10 & 1.69 & .30 & & & & & & & $\begin{array}{l}1.74 \\
1.69\end{array}$ & $\begin{array}{l}.02 \\
.10\end{array}$ & 1.69 & & 1.74 & .20 & 1. 79 & $\begin{array}{r}.24 \\
.16\end{array}$ & $\begin{array}{l}1.77 \\
1.70\end{array}$ & .1 \\
\hline 1.630 & $\mathrm{VW}$ & 1. 62 & MI & & & 1.62 & .15 & & & & & & & & & 1.09 & .10 & 1.09 & .03 & 1. 64 & .27 & 1.61 & .08 & 1.67 & .8 \\
\hline 1.569 & $\mathrm{MI}$ & $\begin{array}{l}1.580 \\
1.580\end{array}$ & VW & 1.595 & MI & 1.58 & .10 & 1.55 & .02 & $1_{-} 60$ & .16 & & & 1.57 & & & & & & 1. 59 & .03 & 55 & & 1. 64 & .5 \\
\hline 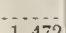 & MT & 1.520 & $\underset{S}{W}$ & 1.51 & M & & & 1.00 & & 1.51 & .12 & & & 1.5 & & 1. 53 & .04 & & & $\begin{array}{l}1.56 \\
1.52\end{array}$ & $\begin{array}{l}.05 \\
.07\end{array}$ & $\begin{array}{r}1.55 \\
-\end{array}$ & .12 & $\begin{array}{l}1.56 \\
1.51\end{array}$ & .1 \\
\hline 1.472 & M & 1. 485 & S & 1.470 & $\mathrm{VW}$ & & & 1.495 & .20 & 1.47 & .05 & 1.485 & $\begin{array}{r}.75 \\
-.0\end{array}$ & 1.490 & .17 & & & & & & & 1.50 & .08 & & $\therefore$ \\
\hline 1.44 & MI & 1.441 & iv & 1.170 & & & & 1.450 & .20 & 1.4 & .08 & & & & & $\begin{array}{l}1.470 \\
1.445\end{array}$ & $\begin{array}{l}.02 \\
.02\end{array}$ & 1.445 & .20 & $\begin{array}{r}1.487 \\
-\end{array}$ & .08 & 1.450 & .08 & 1. 485 & .3 \\
\hline 376 & YW & 423 & VIV & $\begin{array}{l}1.432 \\
1.410\end{array}$ & $\underset{V W}{M}$ & 1. 435 & .13 & & & 1.425 & .05 & & & & & & & & & 1. 420 & .03 & 1.430 & .08 & 1. 402 & .2 \\
\hline 080 & 11 & 1.370 & $1 \mathrm{w}$ & $\begin{array}{l}1.410 \\
1.357\end{array}$ & $M$ & 1.360 & .10 & & & & -.... & & & 1.370 & .13 & 1.350 & & $\begin{array}{r}1.382 \\
-\end{array}$ & .20 & $\begin{array}{l}1.395 \\
1.360\end{array}$ & .07 & 1.390 & .08 & $\begin{array}{l}1.382 \\
1.369\end{array}$ & .5 \\
\hline & $\cdots$ & 1. 340 & $V W$ & & & & & & & 1.350 & .03 & & & & & & & & -.... & $\begin{array}{r}1.360 \\
-\end{array}$ & .01 & & & $\begin{array}{l}1.353 \\
1.353\end{array}$ & $\begin{array}{l}.0 \\
.2\end{array}$ \\
\hline 1.310 & M & 1.315 & W & & WI & 1. & .10 & 315 & .16 & & & & & & & & & & & & & & & 1.336 & .4 \\
\hline $1.26 \overline{7}$ & 5 & 1. 305 & W & 1. 290 & W & & & & & 1. 295 & .05 & & & 1.306 & .09 & 1. 300 & .03 & & $\ldots$ & $\begin{array}{l}1.318 \\
1.296\end{array}$ & $\begin{array}{l}.09 \\
.03\end{array}$ & & & & 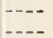 \\
\hline 1.248 & vin & $\begin{array}{l}1.270 \\
1.248\end{array}$ & II & & & 1.270 & .03 & & & .243 & .03 & 1. 266 & .06 & & & $\begin{array}{l}1.262 \\
1.243\end{array}$ & .04 & & $\ldots$ & 1. 275 & .09 & & & & \\
\hline 209 & $\mathrm{~V}-$ & 1. 238 & $W$ & 1. 233 & W & 1. 240 & .15 & & & & $\ldots$ & 1.213 & .15 & & & 1. 210 & $\begin{array}{l}.04 \\
.02\end{array}$ & & & 1. 215 & .05 & & & $\begin{array}{l}\text { 1. } 248 \\
\text { 1. } 235\end{array}$ & .1 \\
\hline 180 & $\begin{array}{l}\text { W } \\
\text { W }\end{array}$ & $\begin{array}{l}1.219 \\
1.182\end{array}$ & W & 1.188 & 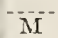 & 1.200 & .10 & & & 1.179 & & & & & & & & 1. 200 & .10 & & & & & & \\
\hline & & $\begin{array}{l}1.182 \\
1.158\end{array}$ & $\pi$ & 1.160 & MI & & - & 1.178 & .02 & $\begin{array}{l}1.179 \\
1.150\end{array}$ & $\begin{array}{l}.03 \\
.05\end{array}$ & $\cdots$ & $\ldots$ & 1.183 & .07 & 1.150 & $-\cdots$ & -.--- & $\cdots-$ & 1.197 & .01 & $\cdots$ & ---- & 1.180 & .2 \\
\hline 1.143 & MI & 1.145 & $\mathrm{MI}$ & 1. 145 & IW & & & 1.145 & .15 & & & & & & & 1.100 & .04 & & . & 1.163 & .08 & $\cdots$ & $\cdots$ & & $\cdots$ \\
\hline 1.125 & W & $\begin{array}{l}1.132 \\
1.107\end{array}$ & $\begin{array}{l}\text { W } \\
\text { VW }\end{array}$ & 1.123 & $\mathrm{VW}^{\prime}$ & 1.138 & .03 & & $\cdots$ & & & $\cdots-e^{-d}$ & & & & 1.125 & .02 & & & & & & & & $\ldots$ \\
\hline 1. 039 & VW & $\begin{array}{l}1.107 \\
1.088\end{array}$ & VW & & & 1.083 & .05 & & & & & & & & & & & 1. 100 & .07 & 1. 103 & .09 & & & $\ldots$ & -.. \\
\hline 1.060 & $\mathrm{M}$ & 1. 063 & IV & 1. 068 & $\mathrm{VIV}$ & &.-- & 1.063 & 10 & & & & & & & 1. 070 & .02 & 1.071 & .25 & & $\ldots$ & & ... & 1.065 & .2 \\
\hline & & $\begin{array}{l}1.055 \\
1.044\end{array}$ & $\frac{M}{W}$ & 1.050 & MI & & & & & & & 1.050 & .04 & & & & & $\cdots$ & & & & & & 1.048 & .5 \\
\hline 1.038 & W & $\begin{array}{l}1.038 \\
\text { 1. }\end{array}$ & WV & 1. 035 & W & 1.037 & .03 & 1.035 & .05 & & & $\ldots$ & . & 1. 031 & .03 & 1.038 & .02 & & & & & & & & -- \\
\hline & $M$ & 1. 015 & MI & 1.015 & w & & ...... & 1. 012 & .08 & 1.011 & .03 & & & & & 1.012 & .02 & ... & .... & & 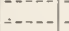 & -.. & & 1. 009 &.$\overline{1}$ \\
\hline 1.000 & w & 1.001 & W & & & & & & & & & & & 1.005 & .04 & 1.000 & .02 & & & & & & & ....... & -..- \\
\hline .980 & $\mathrm{VW}$ & & 81 & $\begin{array}{c}990 \\
---=\end{array}$ & No & .996 & .05 & & & & & & & & & & & .979 & .13 & & & & & & $-\cdots$ \\
\hline & VW & .969 & $\underset{W V}{W}$ & .972 & W & & & & & & & .963 & .01 & & & & & & & & & & & .968 & .2 \\
\hline .9 & W & $\begin{array}{l}.956 \\
.944 \\
\end{array}$ & S & .911 & $\mathrm{VIV}$ & & - & .955 & .05 & & & .940 & .10 & .945 & .04 & .958 & .02 & - & & & & & & .957 & .2 \\
\hline .9 & $\mathrm{VWT}$ & & w & .91 & vi & & & & & & & & & & 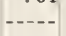 & .920 & .02 & .922 & .03 & & & & & .913 & .4 \\
\hline & W & $\begin{array}{l}.900 \\
.886\end{array}$ & VW & .89 & Vw & -. & ---- & -...... & 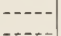 & & & & & & & & & & -..- & & & & & 882 & - \\
\hline .860 & $M I$ & .862 & $\mathrm{~s}$ & .86 & V & & - & & & & & .860 & .04 & .862 & .01 & & & $\ldots$ & & & & & & .873 & .1 \\
\hline .850 & MI & .852 & W & .8 & $\mathrm{VW}$ & & & .850 & .02 & & & & $\ldots$ & & & & & .847 & .03 & & & & & -.... & ... \\
\hline $\begin{array}{l}.83 \\
.82\end{array}$ & VIV & ....... & $\cdots$ & .836 & VW & & & & & & & & & & & & & & & & & & & & -. \\
\hline $\begin{array}{r}.815 \\
792\end{array}$ & M & .815 & W & .812 & Viv & & & & - & 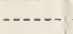 &.- & & - & & $\ldots$ & -. & 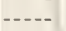 & .810 & .03 & $\ldots$ & . & $\ldots$ & $\ldots$ & -... &.- \\
\hline . 792 & $M$ & & & $\begin{array}{r}.790 \\
.786\end{array}$ & Vw & & & & & & & & & & & & & $\begin{array}{r}800 \\
759\end{array}$ & $\begin{array}{l}.06 \\
.02\end{array}$ & & & & & & $\cdots$ \\
\hline & & & & & & & & & & & & & & & & & & $\begin{array}{l}.731 \\
.723 \\
.671 \\
.666\end{array}$ & $\begin{array}{l}.01 \\
.02 \\
.01 \\
.01\end{array}$ & & & & & & \\
\hline
\end{tabular}

S, strong; M, medium; W, weak; V, very.

$I / I_{1}$ is the ratio of intensity to that of the strongest line. 
fore, to use the heat-of-solution calorimeter as a further check upon the compound composition of the samples of white-coat plaster. From the chemical analyses for the oxide constituents and on the assumptions that have been discussed, the compositions of the aged white coats have been computed as mixtures of $\mathrm{CaSO}_{4} \cdot 2 \mathrm{H}_{2} \mathrm{O}, \mathrm{CaCO}_{3}$, $\mathrm{Ca}(\mathrm{OH})_{2},-\mathrm{Mg}(\mathrm{OH})_{2}$, and $\mathrm{MgO}$. The percentage of $\mathrm{Ca}(\mathrm{OH})_{2}$ has been verified by an independent method - the glycerol-ammonium acetate method. The content of $\mathrm{CaSO}_{4} \cdot 2 \mathrm{H}_{2} \mathrm{O}$ calculated from $\mathrm{SO}_{3}$ has been fairly well checked from the loss on ignition at $200^{\circ} \dot{\mathrm{C}}\left(392^{\circ} \mathrm{F}\right)$.

Although differential thermal analyses were used to show the presence of $\mathrm{CaSO}_{4} \cdot 2 \mathrm{H}_{2} \mathrm{O}$ and $\mathrm{Ca}(\mathrm{OH})_{2}$, as well as $\mathrm{Mg}(\mathrm{OH})_{2}$ and $\mathrm{CaCO}_{3}$, the method, as here applied, does not determine the actual percentages of these constituents. There does not seem to be available any adequate independent method for checking the percentage of $\mathrm{MgO}$. However, if the constituents of the white coats were present in the proportions as given in table 3, the observed heats of solution should agree with those calculated from the algebraic sums of the heats of solution of the individual constituents. The heat of solution of $\mathrm{CaSO}_{4} \cdot 2 \mathrm{H}_{2} \mathrm{O}$ in $2.00 \mathrm{~N}$ hydrochloric acid has been reported by Newman and Wells [31] and the heats of solution of $\mathrm{CaCO}_{3}, \mathrm{Ca}(\mathrm{OH})_{2}, \mathrm{Mg}(\mathrm{OH})_{2}$, and $\mathrm{MgO}$ by
Wells and Taylor [2]. For convenience, the values used in calculating heat of solution are:

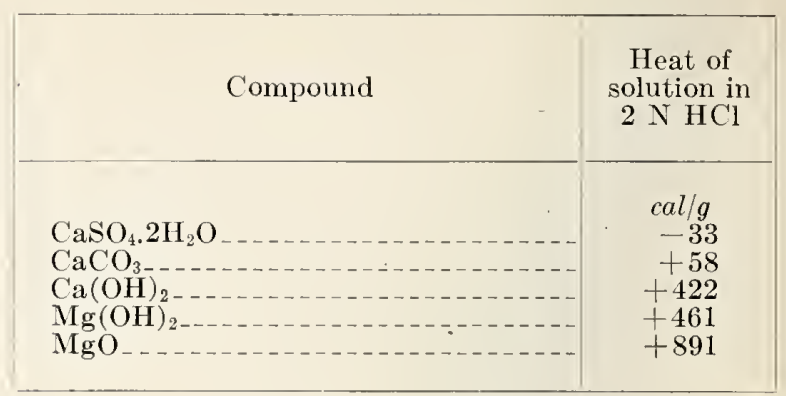

The heats of solution of the plaster samples were calculated from the compound compositions given in table 3. Each constituent was assumed to contribute its heat of solution in proportion to the amount in the plaster sample, and the sums of the contributions are given in column 19 of table 3 as the calculated heats of solution. The observed values of the heats of solution, measured with a precision corresponding to an estimated standard deviation of $\pm 2.1 \mathrm{cal} / \mathrm{g}$, are given in column 18 .

The coefficient of correlation between the calculated and observed heats of solution is 0.993 . (A correlation coefficient of 1.000 represents perfect correlation.)

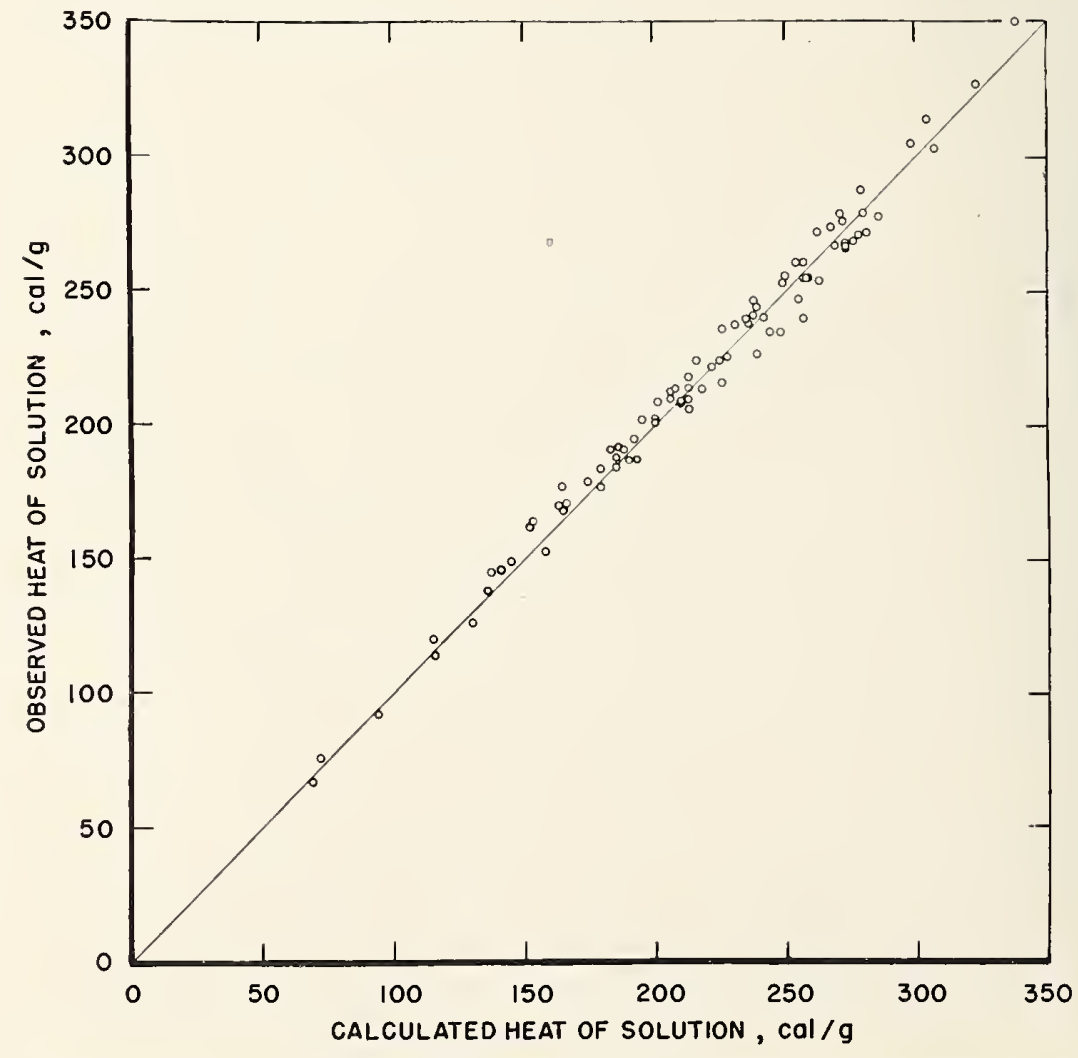

FIGURE 20. Scatter diagram of 88 pairs of calculated and observed heats of solution of samples of failed white-coat plaster. 
Figure 20 is a scatter diagram of the 88 pairs of observed and calculated heats of solution. The line best representing these data, determined by the method of least squares, is $\mathrm{Ob}=5.4+0.980 \mathrm{C}$, regarding the calculated values as the independent variable, and $\mathrm{Ob}=2.6+0.993 \mathrm{C}$, regarding the observed heats of solution as the independent variable. In these equations $\mathrm{Ob}$ and $\mathrm{C}$ represent the observed and calculated values, respectively. In figure 20 is slown only the line representing equality of the calculated and observed values. The tiwo lines representing the equations determined by the method of least squares are not shown in figure 20 , because they would be so close to the line plotted that the paths of the three separate lines could scarcely be followed and the figure would be confusing:

In addition, it miglit be mentioned that the average percentages of $\mathrm{CaSO}_{4} \cdot 2 \mathrm{H}_{2} \mathrm{O}, \mathrm{CaCO}_{3}$, $\mathrm{Ca}(\mathrm{OH})_{2}, \mathrm{Mg}(\mathrm{OH})_{2}$, and $\mathrm{MgO}$, as given in columns $12,13,14,15$, and 16 of table 3 , were ascertained, and that from these average values an average value of the heats of solution was calculated. It was found to be $216 \mathrm{cal} / \mathrm{g}$. The average value of the observed heats of solution, as given in column 18, was also ascertained. It was 217 $\mathrm{cal} / \mathrm{g}$.

The agreement of the calculated and observed values of the heats of solution is strong evidence of the correctness of the assumptions upon which were based the calculations of the compound compositions of the plaster samples. The heats of solution of the plaster's were also calculated from the constitutions obtained by making assumptions as to the distribution of the oxide components other than those which have been discussed. In all cases the values so obtained differed from the observed heats of solution much more than with the present assumptions.

The differences between the observed and calculated values of the heats of solution of the plasters were plotted against each of the oxide and compound constituents shown in table 3 . No correlation was apparent.

It should be emphasized that the accuracy of the chemical analysis and the validity of the assumptions are reflected most in the calculated percentage of the unhydrated $\mathrm{MgO}$ - the last constituent determined. 'The $\mathrm{MgO}$ has the highest heat of solution of any of the constituents, 891 cal/g. An error of 1 percent in the analytical determination of $\mathrm{MgO}$ therefore makes a difference of approximately $9 \mathrm{cal} / \mathrm{g}$ in the calculated value of the heat of solution. Seldom is the difference between the observed and calculated heats of solution more than $9 \mathrm{cal} / \mathrm{g}$. An error in the determination of the quantity of combined $\mathrm{H}_{2} \mathrm{O}$ will make an even greater difference in the calculated heat of solution, as the $\mathrm{H}_{2} \mathrm{O}$, in turn, will be reflected in the final percentage of the computed $\mathrm{MgO}$. One percent of $\mathrm{H}_{2} \mathrm{O}$ will be equivalent to 2.22 percent of $\mathrm{MgO}$ or $20 \mathrm{cal} / \mathrm{g}$ in the computed heat of solution. In no case is there this large difference between the observed and calculated heats of solution. Considering all these factors, the validity of the computed composition of the white coat appears to be firmly established.

\section{Composition of Lime Used in Preparing the White Coat}

It can be secn (table 3 , column 8) that there was considerable magnesia in all the samples of failed white-coat plaster. 'The values in column 8 , however, do not give an indication of the actual percentage of magnesia in the lime that had been. used in preparing the white coat. To obtain this, it is necessary to consider the separate percentages of $\mathrm{CaO}, \mathrm{MgO}$, and $\mathrm{SO}_{3}$, as given in columns 7,8 , and 9, respectively. Calculating the pereentage of $\mathrm{CaO}$ combined with the $\mathrm{SO}_{3}$ to form calcium sulfate and subtracting that $\mathrm{CaO}$ from the total $\mathrm{CaO}$ (column 7), one obtains the amount of $\mathrm{CaO}$ in the lime used. As the $\mathrm{MgO}$ in the plaster came from the lime and not from the gypsum, the percentage of $\mathrm{MgO}$ in the lime (on the nonvolatile basis) can readily be computed. This percentage, disregarding minor constituents, is given in column 20. The range is from 39.0 to 42.1 percent, and the niean is 41.1 percent. The analyses of 185 samples of dolomitic hydrated lime received at the Bureau for test from 1923 to 1940 showed that the average percentage of $\mathrm{MgO}$ (on the nonvolatile basis) was 40.1 , a value in remarkably close agreement with the average of 41.1 percent from the values of column 20 . It can, therefore, be concluded very definitely that in every instance recorded in table 3 a dolomitic lime was used in preparing the white coat-which failed eventually. In not a single instance had a high-calcium lime been used.

\section{Ratio of Lime Putty to Gaging Plaster}

Although many specifications call for the use of three volumes of lime putty to one volume of calcined gaging plaster in the white coat, the proportions are often left to the discretion of the plasterer. Inasmuch as incorrect proportioning of lime putty to gaging plaster has been suggested many times as the cause of plaster failures, the proportions that had been used in preparing the original white coats were calculated from the analyses of the set and hardened white-coat plaster's.

As the analyses of the set white-coat plasters were made on a weight basis, the calculation of the proportion of lime putty to calcined gypsum on a volume basis, in which they are mixed on the job, involves several assumptions. Excepting samples 40 and 46 , table 3 , the calcined grpsum was assumed to be pure hemilivdrate, CaSO .- $^{-}$ $1 / 2 \mathrm{H}_{2} \mathrm{O}$, and $65 \mathrm{lb} / \mathrm{ft}^{3}$ was taken as its bulk density. A cubic foot of lime putty was assumed to contain $45 \mathrm{lb}$ of dry hydrated lime. 

is

The volume ratio of lime putty to gaging plaster

$$
\begin{aligned}
R & =\frac{\text { volume of lime plaster }}{\text { volume of gaging plaster }} \\
& =\frac{\text { mass of dry lime } / 45}{\text { mass of gaging plaster } / 65} \\
& =1.444 \ldots \cdot \frac{\text { weight percent of lime }}{\text { weight percent of gaging plaster }}
\end{aligned}
$$

As all the constituents of white-coat plaster, except for hemihydrate, are supplied by the lime, the ratio can be written

$R=1.444 \ldots \frac{100-\text { weight percent of hemihydrate }}{\text { weight percent of hemihydrate }}$.
A fair approximation of the percentage of hemihydrate used can be obtained from the quantity of gypsum in the finish coat merely by determining the loss on heating at $200^{\circ} \mathrm{C}\left(392^{\circ} \mathrm{F}\right)$ for 1 hour, as this ignition brings about the approximate dehydration of gypsum, $\mathrm{CaSO}_{4} \cdot 2 \mathrm{H}_{2} \mathrm{O}$, to $\mathrm{CaSO}_{4}$.

For a more exact determination it is necessary to analyze the white coat for $\mathrm{CaO}, \mathrm{MgO}$, and $\mathrm{SO}_{3}$. Neglecting the minor constituents $\left(\mathrm{SiO}_{2}, \mathrm{Al}_{2} \mathrm{O}_{3}\right.$, $\mathrm{Fe}_{2} \mathrm{O}_{3}$, etc.) and assuming (1) that the calcined gypsum was pure hemihydrate, (2) that the lime was made up of $\mathrm{Ca}(\mathrm{OH})_{2}, \mathrm{Mg}(\mathrm{OH})_{2}$, and $\mathrm{MgO}$, and (3) that the magnesia was 20 percent hydrated, the ratio (by volume) of lime putty to hemihydrate is

$$
R=1.444 \ldots \frac{\left(\mathrm{CaO}-\frac{\mathrm{MW} \mathrm{CaO}}{\mathrm{MW} \mathrm{SO}_{3}} \mathrm{SO}_{3}\right) \frac{\mathrm{MW} \mathrm{Ca}(\mathrm{OH})_{2}}{\mathrm{MW} \mathrm{CaO}}+0.80 \mathrm{MgO}+0.20 \mathrm{MgO} \frac{\mathrm{MW} \mathrm{Mg}(\mathrm{OH})_{2}}{\mathrm{MW} \mathrm{MgO}}}{\mathrm{SO}_{3} \frac{\mathrm{MW} \mathrm{CaSO}{ }_{4} \cdot{ }_{2} / \mathrm{H}_{2} \mathrm{O}}{\mathrm{MW} \mathrm{SO}{ }_{3}}},
$$

where $\mathrm{MW}$ is the molecular weight of the compound in question and $\mathrm{CaO}, \mathrm{SO}_{3}$, and $\mathrm{MgO}$ represent the weight percent of these oxides in the analysis of the white-coat plaster. This relation becomes

$$
R=0.7967 \frac{\left(\mathrm{CaO}-0.7005 \mathrm{SO}_{3}\right) 1.3213+1.0894 \mathrm{MgO}}{\mathrm{SO}_{3}},
$$

and this can be written

$$
R=\frac{1.0527 \mathrm{CaO}+0.8679 \mathrm{MgO}}{\mathrm{SO}_{3}}-0.7374
$$

This formula was used in obtaining the values recorded in column 21 of table 3 . Plaster failures from which these samples were taken occurred with ratios of lime putty to $\mathrm{CaSO}_{4} \cdot \frac{1}{2} \mathrm{H}_{2} \mathrm{O}$ as low as 0.8 and as high as 9.8 . Figure 21 is a distribution diagram of the ratios of lime putty. to $\mathrm{CaSO}_{4 \cdot 1 / 2} \mathrm{H}_{2} \mathrm{O}$ (by volume) for the 88 samples. The average ratio, taken from the grouped data, was 4.0 , and 90 percent of the samples were scattered more or less symmetrically about that figure. Only the samples with ratios of 7.0 and higher ( 8 in all) appear to fall out of that distribution.

At this point attention should be called to the volume ratio of lime putty to gaging plaster in separate sections of a white coat. Samples 24, 25 , and 26 of table 3 give the analysis and other properties of three sections of a white-coat plaster that was originally about $1 / 8$ inch in thickness. The outside section next to the paint is sample 24 , that next to the base coat of plaster is 26 , and the intervening section is 25. From the table it can be seen that the percentage of gypsum, $\mathrm{CaSO}_{4} \cdot 2 \mathrm{H}_{2} \mathrm{O}$, (column 12) increased from the outside surface of the white coat inward. In other words, the outside surface of the white coat was richer in lime.

This condition is reflected in the calculated

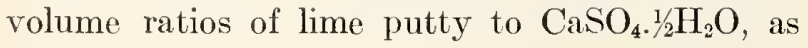

given in column 21 for these three sections. It is also reflected in the decreases of the heats of solution attending a decrease in the percentage of lime and a corresponding increase in the percentage of gypsum from the outside surface inward.

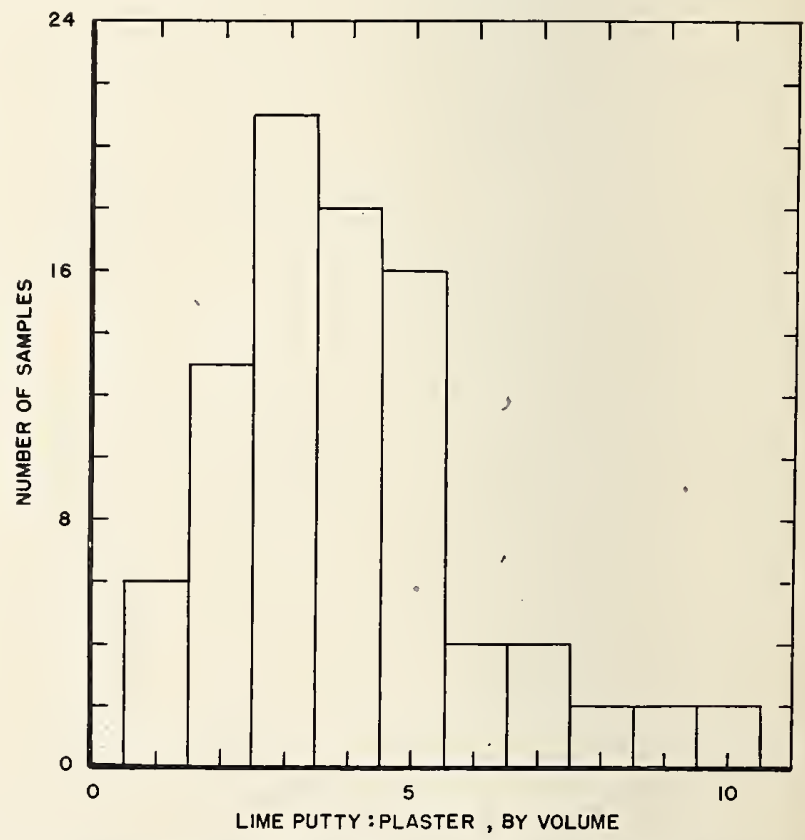

FIgURE 21. Distribution diagram of the ratios (by volume) of lime putty to gaging plaster ( $\mathrm{CaSO}_{4} .1 / 2 \mathrm{H}_{2} \mathrm{O}$ ) for $88(\mathrm{~N})$ samples of white coat.

The average ratio $(\overline{\mathrm{X}})$ is 4.0, and the standard deviation $(\sigma)$ is 2.0 . 
It seems unlikely that the plasterer changed the proportion of the white-coat mix during the application of the successive layers of white coat.

To determine the significance of the greater proportion of lime in the outer surfaces, additional samples were taken from some freshly plastered walls where it was known definitely that the separate layers of white coat as applied were of the same composition. Again this emrichment of lime in the outer surface was observed. This has brought the suggestion that in the troweling process while finishing the application of the white coat there is a tendency to "float" the lime to the surface. This is akin to the formation of "laitance" (or a separation of the cement paste) accompanying excessive working, or troweling, of concrete or stucco.

Plastering experiments also revealed that this floating of the lime was greater where the white coat was applied to a base coat that had not dried sufficiently. In fact, it can be so aggravated when the base coat is very "green" that the outside surface of the white coat is composed primarily of a very thin coating of hydrated lime. Consequently, when the white coat dries, this outside coating of "whitewash" with little or" no gypsum can be easily rubbed off with the hand. Such a surface is undesirable to receive oil paint, and some few experiments at the Bureau showed that such surfaces also required larger quantities of paint than did white coat that had been applied on a drier base and had not been troweled so much. The subject, however, needs further investigation for its bearing on painting plastered surfaces.

\section{Extent of Carbonation of the Lime}

It is pointed out in section IV, 5, page 15 , that inasmuch as the combination of $\mathrm{Ca}(\mathrm{OH})_{2}$ with $\mathrm{CO}_{2}$ from the air, to form $\mathrm{CaCO}_{3}$, proceeds slowly in normally dry plaster, but more rapidly when the optimum amount of moisture is present, it can be predicted that the extent of carbonation will vary greatly. To determine the degree of carbonation, calculations were made from the data presented in table 3 . Although it can be seen from column 13 that there was considerable $\mathrm{CaCO}_{3}$ in all the samples of failed white-coat plaster, there is no indication of what percentage of $\mathrm{Ca}(\mathrm{OH})_{2}$ in the lime had been carbonated in the preparation, application, and subsequent treatment of the white coat. This percentage carbonation of the $\mathrm{Ca}(\mathrm{OH})_{2}$ can be calculated from the data in table 3. Columns 13 and 14 contain the equivalent of all the $\mathrm{Ca}(\mathrm{OH})_{2}$ derived from the lime putty. In addition, there is included whatever $\mathrm{CaCO}_{3}$ existed as an impurity in the calcined gypsum, which is assumed negligible in this calculation. The percentage of $\mathrm{CaCO}_{3}$ in column 13 is multiplied by 0.7403 to obtain the equivalent percentage, $A$, of $\mathrm{Ca}(\mathrm{OH})_{2}$. This, added to the percentage of $\mathrm{Ca}(\mathrm{OH})_{2}$ in column 14 , gives the total, $B$, supplied by the lime. The value $A$ is divided by $B$ and multiplied by 100 . The result is recorded in column 22 of table 3 as the percentage carbonation of $\mathrm{Ca}(\mathrm{OH})_{2}$. The range is from 9 to 100 percent and the mean is 60 percent.

\section{Expansion in Autoclave}

It is well known that if materials containing free magnesia are steamed in an autoclave, forced hydration of the $\mathrm{MgO}$ to $\mathrm{Mg}(\mathrm{OH})_{2}$ is brought about rapidly.

Many of the plaster samples were cut into narrow slabs several inches long and steamed in a suitable autoclave for 1 hour at a steam-gage pressure of $120 \mathrm{lb} / \mathrm{in}^{2}{ }^{2}$. In most instances the specimens expanded markedly, in some cases as much as 10 to 15 percent. Because the thin specimens warped badly and often cracked, no satisfactory correlation could be obtained between the percentage of expansion and the percentage of free $\mathrm{MgO}$ in the samples. Invariably the buckling was convex in a direction indicating that the material next to the troweled surface had expanded more than that next to the base coat. The outer portion of the white coat was denser than the interior, because the pressure of the trowel more completely closed the pores of the outer portion. In addition, because of this troweling action, the magnesia is more concentrated in the outer region. Consequently, the hydration of the magnesia caused a greater expansion in this region.

This convex expansion is well illustrated by figures 22 and 23 . Figure 22 is a cross section of white coat adhering to a sanded gypsum-plaster base coat. The sanded base coat had been applied over a concrete beam, and a thick white coat had been used to straighten up the surface. The bond between the sanded gypsum base coat and concrete beam had failed in service. Figure 22 was made prior to autoclaving. Figure 23 shows the same specimen after autoclaving. Note the expansion and convex bending of the white coat, which in turn caused a bending and deformation of the base coat. It was the preliminary very slight and not readily discernible deformation of the base coat that had resulted in a shearing of the sanded base coat from the concrete base. The autoclaving merely completed the hydration of the $\mathrm{MgO}$ remaining in the white coat, amplified the expansion, and showed clearly the directions of the forces being set up.

Specimens of white coat prepared from highcalcium or dolomitic limes containing little or no unhydrated oxide showed little or no expansion when autoclaved. This demonstrates that if the oxide is hydrated before the white coat is fabricated the expansion and attendant bulging does not occur.

Recently, Wells, Clarke, and Levin [21] published a paper on the expansive characteristics of 80 hydrated limes and proposed therein an autoclave test for soundness. They showed that specimens fabricated from high-calcium limes and from 

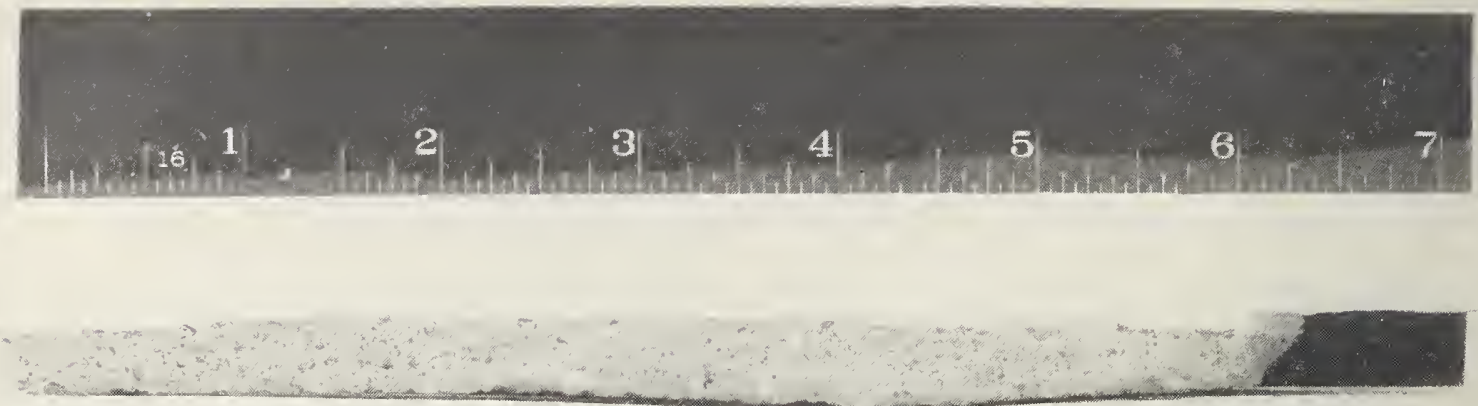

FIGURE 22. A cross section of white coat adhering to a sanded gypsum plaster base coat that had been applied over a concrete Photograph made prior to autoclaving. beam.

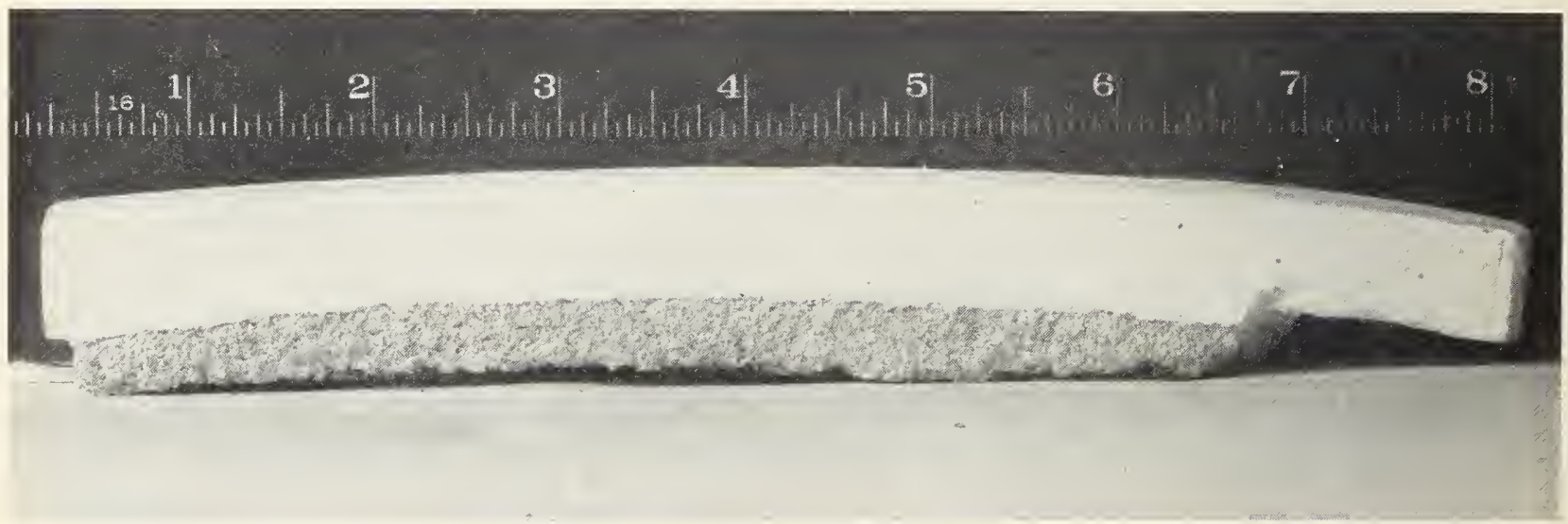

FIGURE 23. The specimen shown in figure 22, after autoclaving.

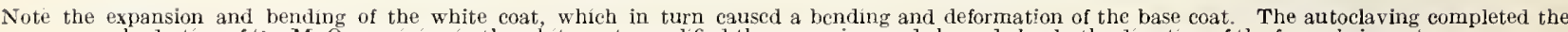
hydration of the MgO remaining in the white coat, amplified the expansion, and showed clearly the direction of the forces being set up.

those highly hydrated dolomitic limes containing a small percentage of unhydrated oxides expanded insignificantly, whereas specimens prepared from the regularly hydrated dolomitic limes that contained considerable unhylrated $\mathrm{MgO}$ gave large expansions. Their results clearly demonstrate that the marked expansion attending the hydration of $\mathrm{MgO}$ to $\mathrm{Mg}(\mathrm{OH})_{2}$ must be considered of prime importance in causing plaster failures of the type studied in this investigation.

\section{Investigation of Some Base Coats}

Up to this point the discussion of plaster failures has been confined largely to the white coat. During the field surveys, however, due consideration was given to the condition of the base coats. In the majority of cases, those responsible for building maintenance concurred with the statement of the manager of the Providence Building, mentioned in the introduction of this paper, to the effect that "We have had no trouble at all with the brown coat of plaster but altogether with the white or skim coat of plaster." 'This, of course, does not mean that all the base coats of plaster were perfect. In those instances where the basecoat plaster fell into the perfect or very satisfactory category, the failures in the white coat invariably resulted in a bulging of the white coat and a shearing away from the base coat, with the base coat remaining intact and firmly attached to its base. On the other hand, where the base coat was soft and weak the white coat in bulging away from the base coat invariably pulled some sanded plaster from the underlying base coat. In both cases, the characteristic failmes of the white coat, with the bulging and shearing away from the base coat, were identical.

It should be emphasized that most of the buildings inspected were of the monumental type, or, at least, of the better type of construction. The findings, therefore, are not necessarily representative of the type of plastering and workmanship that may be too frequently found in speculative home construction, where too-thin coats of plaster are apt to be encountered, as well as oversanding of the base coats. Nor can the results of these surveys be interpreted as showing that oversand- 
ing and apparently bad plastering practices are not to be found in what may be classified as the better type of plastering.

Reviewing the knowledge gained from the surveys and investigation, it appears that it would have been desirable to have obtained samples of the base coat in every instance where white-coatplaster failure occurred. Had this been done, knowledge would have been gained of the compositions of the base coats of plaster as commonly applied. Unfortunately this was not done. During the surveys, however, the question as to the compositions of the basa coats arose and samples were taken for analysis. The compositions of 24 of these that are believed to be of special interest are included in this study. The data are given in table 5 .

Inasmuch as it was not known in many cases whether the samples of sanded plaster were gypsum or lime plaster, the samples were treated with hydrochloric acid rather than with the ammonium acetate solution prescribed in the determination of the sand content of set gypsum plaster [28].

It should be noted from the chemical analyses that there were appreciable percentages of $\mathrm{MgO}$ (column 6) in most of the samples of sanded plaster. Inasmuch as it was reported in many instances that gypsum plaster was used in the preparation of the base coat, it must be assumed that either lime containing magnesia was used, or that the magnesia was derived from the sand. Because reports of chemical analyses of sand, given in U. S. Geological Survey Bulletins, indicate that most of the territory covered in the survey in the Middle West States contains considerable quantities of dolomitic limestone, the presence of dolomitic limestone is a reasonable assumption as to the source of the $\mathrm{MgO}$. Such an assumption is indicated further by the rather low $\mathrm{SiO}_{2}+\mathrm{R}_{2} \mathrm{O}_{3}$ content of the sanded plaster. Furthermore, the quantity of $\mathrm{CO}_{2}$ present was sufficient to have carbonated all the $\mathrm{CaO}$ not present as $\mathrm{CaSO}_{4} \cdot \frac{1}{2} \mathrm{H}_{2} \mathrm{O}$ and, in addition, all the magnesia. If the magnesia had been present as a constituent of dolomitic lime in these instances, it is doubtful that it would have been appreciably carbonated because the magnesia in the adjacent white coats showed no carbonation.

In many cases the base coats were apparently sanded gypsum plaster. The proportion of plaster to sand in column 18 is given as pure $\mathrm{CaSO}_{4} \cdot \frac{1}{2} \mathrm{H}_{2} \mathrm{O}$ to the sum of $\mathrm{SiO}_{2}+\mathrm{R}_{2} \mathrm{O}_{3}+\mathrm{CaCO}_{3}+\mathrm{MgCO}_{3}$. In column 19 the proportion is calculated on the basis that the plaster contained 85 percent of $\mathrm{CaSO}_{4} \cdot 1 / 2 \mathrm{H}_{2} \mathrm{O}$.

Sample 1 represents a rather weak and what appeared to be an oversanded base coat. Analysis showed that this base coat was composed of 1 part of gypsum plaster to 6.5 parts of sand (column 19). It was, therefore, badly oversanded. Such oversanding is to be condemned.

Base-coat sample 2 represents the composition used in the annex of the building from which sample 1 was taken and shows that in this case a lime plaster was used. Again, failure of the white coat resulted in the formation of bulges. But still worse, the presence of the unhydrated $\mathrm{MgO}$ in the lime used in the preparation of the lime-sand base coat caused expansion; thus, in addition to the expansion of the white coat, there was an expansion of the base coat. Consequently, most of the plaster, including white and base coat, had to be replaced. With the gypsum base coat, only the badly oversanded portions had to be replaced.

Samples 3 and 4 represent the compositions of the base coats of sanded gypsum plaster taken from the ceilings of the nurses' home of a large hospital in which there have been extensive failures of white coat. In general, the brown coats were hard and firm and sufficiently rough for good bond. Despite this, white-coat-plaster failures started in this building 9 years after it was erected and are continuing. They occur most extensively during the spring and summer, especially following periods of high temperature accompanied by high relative humidity.

Sample 5 was taken from the sidewall of an outside corridor of a large hotel. The frame is structural steel, fireproofed, with reinforcedconcrete floor slabs. In the ceilings, suspended metal lath was attached close to the bottom of the concrete joists (furred type). The plaster on the ceilings was three-coat work; on walls, two-coat work. The finish coat was smooth and hard. White-coat failures, characterized by the formation of bulges, have occurred on ceilings and on walls throughout the building, especially in corridors. Failures began in 1935, 8 years after the building was erected. They occur most extensively during the summer. $\mathcal{A}$ plasterer is continuously engaged by this hotel to repair the failures. In general, the brown coat was firm and hard. However, a sample of a portion that seemed to be somewhat weaker and possibly oversanded was taken from the side wall of an outside corridor (sample 5). Analysis verified that this particular sample was somewhat oversanded (columns 18 and 19).

Base-coat sample 6 was taken from a 12-story office building where the frame was of structural steel that was fireproofed. The floors were of concrete joists with sheet-metal-lath fillers. The outside walls were of brick furred with ceramic hollow tile. The interior partitions were of ceramic hollow tile. Two-coat work was used on ceilings and walls. The finish coat was smooth and hard.

In most cases the failures were characterized by a separation of the white coat from the brown coat. Failures occurring before the time of survey had been confined to ceilings, but were starting on outside and inside walls. The base coats were rather soft and weak. This was the reason for taking sample 6. Analysis showed that the gypsum: sand ratio was $1: 4.7$ (column 
TABLE 5. Constitution of base coats obtained from various buildings, showing the chemical analysis, calculated compound composition, proportion (by weight) of $\mathrm{CaSO}_{4} \cdot \frac{1}{2} \mathrm{H}_{2} \mathrm{O}$ to $\mathrm{SiO}_{2}+\mathrm{R}_{2} \mathrm{O}_{3}+\mathrm{CaCO}_{3}+\mathrm{MgCO}_{3}$ and of gypsum plaster to sand, or of lime to sand, or of lime to gypsum plaster to sand

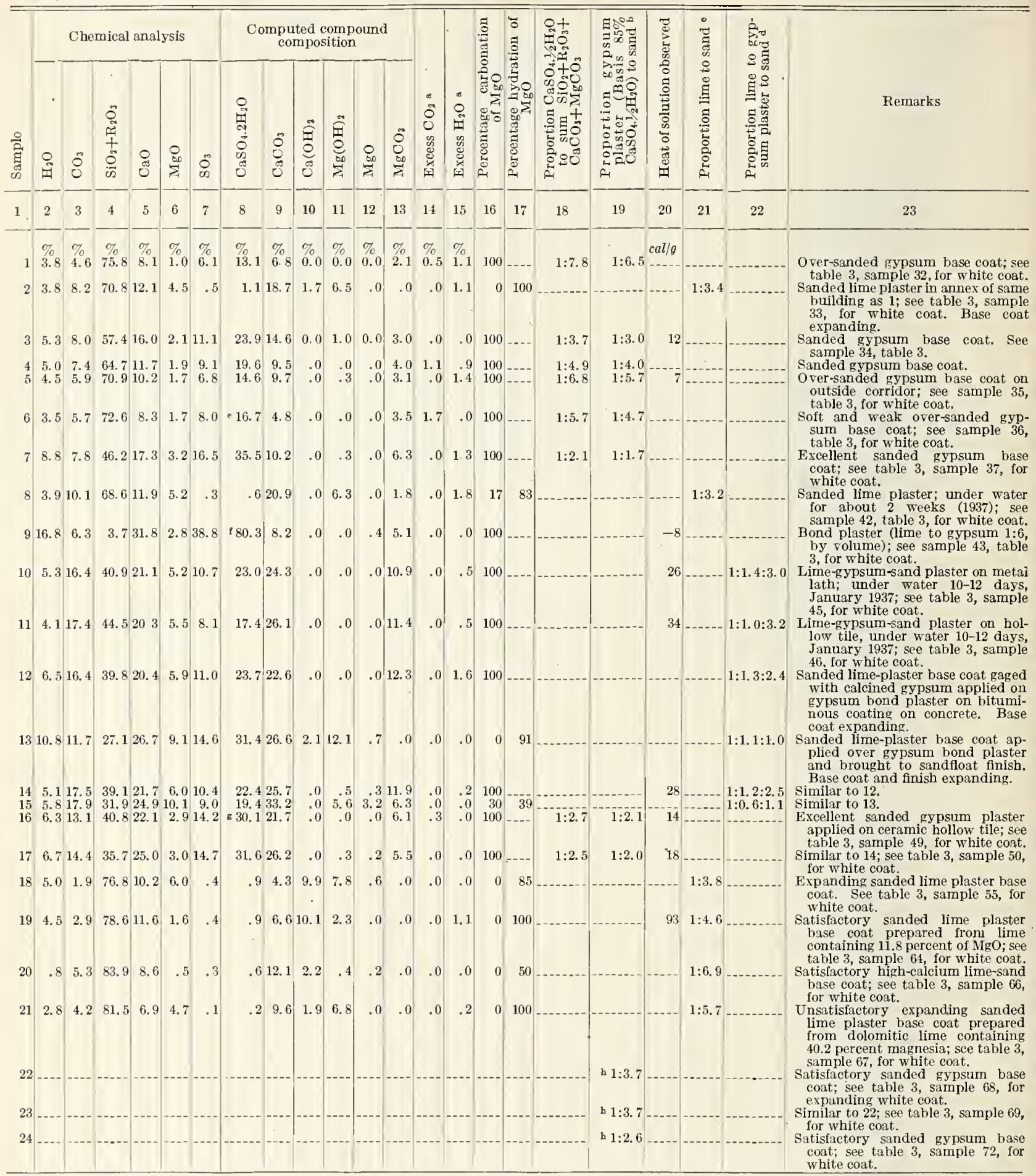

a Where $\mathrm{MgCO}_{3}$ is derived by carbonation of the lime, the excess $\mathrm{H}_{2} \mathrm{O}$ is assumed to bo combined with $\mathrm{MgCO}_{3}$ as a hydrous compound. Elsewhere the excess $\mathrm{CO}_{2}$ and excess $\mathrm{H}_{2} \mathrm{O}$ are assumed to be present as some hydrous carbonated material in the sand.

b Sand, column 19, is the sum of $\mathrm{SiO}_{2}, \mathrm{R}_{2} \mathrm{O}_{3}, \mathrm{CaCO}_{3}, \mathrm{MgCO}_{3}$, excess $\mathrm{CO}_{2}$, and excess $\mathrm{H}_{2} \mathrm{O}$, less the 15 percent insoluble in the calculated gypsum plaster. c Calculated on the basis that the sand is the sum of $\mathrm{SiO}_{2}$ and $\mathrm{R}_{2} \mathrm{O}_{3}$, that a hydrated lime was used in which all the $\mathrm{CaO}$ and one-fifth of the $\mathrm{MgO}$ was hydrated, and that the $\mathrm{SO}_{3}$ (as $\mathrm{CaSO}_{4}$ ) was present as an impurity in the lime. d Calculated on the basis that the original lime was preparcd from a dolomite and contained 60 percent of $\mathrm{CaO}$ and 40 percent of $\mathrm{MgO}$ and that in the hydrated lime all of the $\mathrm{CaO}$ and one-fifth of the $\mathrm{MgO}$ was hydrated. The remaining nongypsum $\mathrm{CaO}$ is considered to be present as calcite in the sand which is ealculated to contain in addition the $\mathrm{SiO}_{2}, \mathrm{R}_{2} \mathrm{O}_{3}$, and excess $\mathrm{CO}_{2}$. e Contains in addition 0.4 percent of $\mathrm{CaSO}_{4}$

1 Contains in addition 2.5 percent of $\mathrm{CaSO}_{4}$.

$\mathrm{g}$ Contains in addition 0.3 percent of $\mathrm{CaSO}_{4}$.

$\mathrm{b}$ Determined by the ammonium acetate method for determining the sand content of set gypsum plaster. 
19). Failures began about 6 ycars after the completion of the building and are general throughout all stories. They occur most rapidly during the spring and summer. The building superintendent stated that after a hot, humid niglit he could be sure that plaster repairs would be necessary the next morning. The superintendent stated that $\$ 10,000$ lias been expended for plaster repairs in a period of 5 years.

A building where the base coats were in very good condition, but where, nevertheless, there were failures in the white coat is exemplified by the data pertaining to sample 7 . In this case the analysis revealed that the proportion of gypsum to sand (on an assumed purity of 85 percent for the gaging plaster, $\mathrm{CaSO}_{4} \cdot{ }_{2}^{1 / 2} \mathrm{H}_{2} \mathrm{O}$ ) was as rich as $1: 1.7$ (column 19).

One of the very interesting cases of plaster failure involved expansion of both a sanded base coat and a white coat where a partially hydrated dolomitic lime had been used in their preparation. These plaster failures occurred in a six-story building, with basement, covering about a block. The frame of the building was of structural steel that was fireproofed. The floor slabs were of reinforced concrete and concrete joists with ceramic-hollow-tile fillers; the outside walls were of stone and brick with tile furring; the interior partitions were of hollow tile. Except for a few suspended metal-lath ceilings, the plaster bases were of masonry construction. Three-coat work was used over metal lath and concrete. The scratch coat on concrete was gypsum bond plaster. From table 5, sample 8, column 21 , it can be seen that the base coat was a lime-sand plaster $(1: 3.2)$.

Failures consisted of separation of the white coat from the brown coat, bulges, and a considerable amount of separation of the lime-plaster base coat from the masonry backing. Failures began in 1938 , about 5 years after the plastering was completed. They occur most rapidly during the summer and are general throughout all stories.

During the flood of the Ohio River in 1937, water rose to within 6 inches of the first-floor slab. Plaster work in the basement was under water for a period of about 2 weeks, and it did not completely dry out for months. Such an exposure to water should have rather completely hydrated the magnesia; from column 12 it can be seen that there was no free $\mathrm{MgO}$ left in the base coat at the time of the survey in 1940. Not only was all of the $\mathrm{MgO}$ hydrated, but a portion of the $\mathrm{Mg}(\mathrm{OH})_{2}$ was in turn converted to the carbonate, nesquehonite, $\mathrm{MgCO}_{3} .3 \mathrm{H}_{2} \mathrm{O}$.

The hydration of the magnesia attending this soaking was also reflected in the data on the white coat (table 3, sample 42). From column 17 of table 3 , it can be seen that 83 percent of the $\mathrm{MgO}$ had been hydrated; from column 22 , that 94 percent of the $\mathrm{Ca}(\mathrm{OH})_{2}$ had becn carbonated.

From a consideration of the volume changes accompanying the hydration and carbonation of lime products (table 2 ), it might be concluded that the cxpansion should have been of such a magnitude that the base and white coats would liave failed throughout. A probable explanation as to why the failures were not extensive is that when the plaster was wet it was also soft; and that, therefore, stresses set up by the increase in volume could be relieved. Failures characterized by bulging of both the sand-lime base coat and limegypsum finish coat were prevalent in the stories above the flooded area.

Samples 9, 10, and 11 were taken, in another city, from a building that was partially flooded during the rise of the Ohio River in 1937. The construction of this four-story building with its basement and subbasement was similar to the one just described.

The plaster bases were of masonry, except for a few suspended ceilings of metal lath. Some concrete columns were encased with metal latl. Plywood forms had bcen used for the concrete work, and the concrete surfaces were exceptionally smooth. Over most of the ceilings, the white finish coat was applied directly to the concrete, but in certain limited areas a thin brush coat of bond plaster had been applied. In both cases these bases were far from ideal for the application of white coat. In only one other building was there encountered this bad plastering practice of merely brushing on the bond coat. Sample 9 represents bond plastcr taken from a concrete column which was above the flood level. The ratio of lime putty to gypsum (by volume) was $1: 6$. The analysis of the corresponding white coat is given in table 3 , sample 43 .

Samples 10 and 11 of table 5 pertain to the sanded base coats, and it should be noted that these coats were essentially lime-gypsum-sand plaster. Inquiry revealed that the lime putty used in preparing the base coat was obtained from a lime-putty plant that slaked a dolomitic quicklime with an excess of water and then aged the putty to assure complete hydration.

Both samples 10 and 11 were taken from the subbasement and had been thoroughly soaked with water as a result of the flood. It was stated by the building manager that no extensive plaster repairs were required after the flood water had subsided. This is not surprising when it is realized that not only were the flooded plasters soft, but also that only thoroughly hydrated and aged lime putty was used originally in preparing the base coats - thus additional wetting could not have been attended by any subsequent hydration and increase in volume. In contrast to the other building that was also flooded, there was no evidence of any base-coat failure in the upper. floors.

Base-coat samples $12,13,14$, and 15 were all taken from the annex of a large building where the type of failures occurring in the sanded base coat were similar to those noted elsewhere in whitefinish-coat work. 
The structure in question was a 20-story office building about a block long and one-half block wide. The original portion was built in 1910 ; the annex, in 1920. 'The frames of both were of structural steel and reinforced concrete. The floor slabs in both instances were of reinforced concrete. The outside walls were of stone and brick, furred with ceramic tile. In the original building, the failures consisted in the separation of the white coat from the hard and firm gypsum base coat. Inasmuch as these failures were typical of those found repeatedly throughout the surveys, no sample was taken of either the base or white coat.

There was no white coat in the annex; instead the base coats were brought to a sand-float finish. As shown in table 5, column 22, they were essentially lime base coats gaged with calcined gypsum. In other words, the plaster might be termed a "sanded white-coat finish". In considerable areas, a bituminous coating was applied over concrete surfaces. Over this bituminous coating, gypsum bond plaster was applied and scratched to receive the lime base coat gaged with calcmed gypsum. The ultimate expansion of the sanded coat, resulting from the slow hydration of the $\mathrm{MgO}$ in the lime used in its preparation, caused numerous separations of the plaster from the bituminous base material. Invariably the bituminous material was hard and brittle-it had lost all of its "tackiness". Thus the inner surface of the bituminous coating (the weakest bonding material in the plaster work) was at the interface where separation occurred. Where no bituminous material was used, the failures were characterized by the separation of successive layers of the sand-float plaster.

If one were to select the building that showed the greatest variety of white-coat-plaster failures, it would be a certain small Post Office of one story and basement.

The frame was structural steel, fireproofed. 'The floor slabs and first-story ceiling slabs were reinforced concrete. The outside walls were of brick furred with ceramic hollow tile. The inside partitions were of hollow tile. Thus the plaster bases were of concrete and masonry, except for some suspended ceilings of metal lath and metal lath over the lookouts. The application of the white coat directly to the rough concrete was in accordance with the specifications. 'There was two-coat work on the ceramic hollow tile and three-coat work on the metal lath. The finish coat was smooth and hard, and there was every evidence of good workmanship. The ratio of lime putty to gaging (by volume) was 3.6 (see sample 49 , table 3 , column 21).

The failures on the concrete ceiling in the workroom began about 5 years after the building was constructed. They were progressive for the next 9 years; at the end of that time all the plaster on the ceiling was removed, and the rough concrete slab was painted.
Failures were found not only on this and other ceilings but also on the furred outside walls, concrete and brick inside walls, hollow-tile interior partitions, and metal lath and plaster lookout walls. These failures all showed the typical bulging and separation of the white coat from the base coat. The gypsum base coats were very liard and firm. The proportion of gypsum plaster to sand was close to $1: 2$ (table 5 , column 19 , samples 16 and 17). The sanded base coats had been left sufficiently rough to permit a good bond with the white coat. It was conceded that no better base coats had been seen on the survey. Nevertheless, at the time of the survey in 1940 (26 years after the building had been erected), the white coat was still bulging away from the walls, and the plastering had become a network of patches. To those who believe that all concrete surfaces should be covered with metal lath, it should be pointed out that, in this building, covering the concrete lookouts with metal lath did not prevent white-coat-plaster failures. Again, it should be emphasized that the failure of plaster over concrete surfaces was almost invariably characterized by bulges in the white coat and only secondarily by failures of the bond between the bond plaster and the concrete. Provided the concrete surface is sufficiently rough, there seems no logical reason why the white coat should not be applied directly to the concrete, granting, of course, that the materials used in the preparation of the white coat will not undergo subsequent expansion. If the lime is unsound, covering the concrete surfaces with metal lath will not prevent failure in the white coat.

Four samples of base coats $(18,19,20$, and 21$)$ were obtained from post offices in various parts of the country. In each case, it can be seen from table 5 , column 21 , that the base-coat plasters were lime-sand plasters. In two of these (18 and 21 ), there were not only failures in the white coat, but also bulging of the lime-sand base coats. Apparently both of these were prepared from a regularly hydrated dolomitic lime. In the other cases (19 and 20), there were failures in the white coats, but no trouble in the base coats. The data indicate that the lime used in sample 19 was not dolomitic as it contained only 12.4 percent of total magnesia. The lime used in base-coat sample 20 was definitely high-calcium.

The remaining samples in table $5(22,23$, and 24) were taken from buildings where the plaster failures were entirely confined to the white coat. Samples 22 and 23 were from a building where the hard gypsum base coats were proportioned (column 19) as 1:3.7, gypsum to sand, by weight.

The other (number 24) was from a building where the hard gypsum-sand plaster was proportioned as 1 part of plaster to 2.6 parts of sand (column 19).

For several of these saniples, the heat of solution (column 20) was determined. It should be noted 
that the valucs obtained were very much lower than those obtained for the white coat. This is due to the fact that the base coats were comprised largely of sand with a smaller quantity of cementitious material. The cemcntitious matcrial in turn was composed to a large cxtcnt of gypsum (which has a negative heat of solution) or (in the case of lime base coats) of calcium and magnesium carbonates that have low positive heats of solution.

Neglecting the $\mathrm{SiO}_{2}+\mathrm{R}_{2} \mathrm{O}_{3}$ in the computed heat of solution of the white coat did not introduce any appreciable crror, as these constituents, as has been pointed out previously, were usually less less than 1 percent. On the other hand, when the so-called sand contcnt comprises the bulk of the sample, its effect on the heat of solution cannot be ignored. Evidently there were in the sands certain mineral constituents that evolved a small quantity of heat when treated with the $2 N \mathrm{HCl}$ solution. The observed heats of solution were invariably a little highcr than those computed from the calculated heats of solution based on the calculated compound composition on the assumption that the heat evolved by the sand was zero. As thc original sands used in the preparation of the plasters were not availablc, no correction can be made for the possible amount of this heat evolved.

\section{Possible Causes of Failure of White-Coat Plaster Other Than Hy- dration of Magnesia}

Many causes for the bulge type of plaster failure have been suggested by architects, plastercrs, lime manufacturers, and others. None of these causes when considered in detail seems adequate for explanation of the observed failures. Neverthcless, some of those more often suggested will be discussed at some length to point out how they fail to account for the observed phenomena. For this purpose will be considered drying shrinkage of concrete, differences in thermal expansion between the backing and the various layers of plaster, workmanship, improper gaging, improper painting, paint shrinkage, vibration, and structural movements.

\section{Shrinkage of Concrete}

As stated previously, failures in the white coat of plaster over concrete bases were of frequent occurrence. It is well known that concrete undergoes a slight shrinkage on drying after it has been fabricated. This shrinkage has often been cited as a cause of the formation of bulges in the white coat.

Figure 24 shows a marked failure that occurred in white coat along the side of a concrete beam. The movement, whether ascribed to an expansion of the white coat or to a shrinkage of the concrete, resulted in the separation of a little of the bond plaster from the concrete base. However, over the remaining area of the failure, the strong and well-seratehed coat of bond plaster remained intact.

Chemical and thermal analyses indieated that the white coat (sample 10, table 3) had been prepared from a mixture of gypsum gaging plaster and a dolomitic lime that had contained considerable unhydrated $\mathrm{MgO}$. Nlthough 70 pereent of the magnesia had hydrated at the time of the failure, which was about 12 years after the building had been constructed, the sample still contained 5.2 percent of $\mathrm{MgO}$ to be hydrated, with its certain attending expansion. Calculation based on measurements of the bulge in the white coat revealed that a linear expansion of approximately 0.5 percent appears necessary to account for a separation of the magnitude shown in figure 24. The maximum drying shrinkage of concrete is, in general, of the order of magnitude of 0.05 percent $\rightarrow$ a value one-tenth of that necessary to account for the formation of the bulge in question. It should be noted that not even this total amount of shrinkage would be available to form a bulge as white-coat plaster also shrinks on drying and would tend to offset any such effect. Furthermore, the bulk of the shrinkage of a concrete beam in a building should be completed at the end of a year, whereas the formation of this bulge in the white coat was delayed for 12 years. Finally, like this one, the other failures over concrete have been delayed for years and have bcen very largely scparations between the white coat and the gypsum bond plaster-not between the bond plaster and the concrete base.

Conscquently, it can be concluded that the shrinkage of concrete cannot account for the bulging of the white coat.

\section{Differences in Thermal Expansion}

White-coat failures have often been ascribed to the differences in thermal expansion of white- and base-coat plaster. A search of the literature at the time that the surveys wcre first made failed to reveal any published data on the coefficients of thermal cxpansion of these materials other than those determined at the Bureau by McMurdie and Marsh [32]. They reported (1932) for set gaging plaster coefficients ranging from 8.3 to $9.5 \times 10^{-6} / \mathrm{deg} \mathrm{F}$. Consequently, determinations were made of the coefficients of thermal expansion of some specimens made from white-coat and sandcd base-coat materials, as well as one from gaging plaster.

The coefficient of thermal expansion of the set gaging plaster was found to be $9.7 \times 10^{-6}$. This value is in close agreement with $9.5 \times 10^{-6}$, the upper limit of the values recorded by McMurdie and Marsh.

The white-coat specimens were prepared from gypsum gaging plaster with finishing hydrated dolomitic lime or with high-calcium lime, by mixing (by volume) one part of the gaging plaster with three parts of the lime as putty. The mixtures were cast into bars, 10 by 1 by 1 inch. In 
CEILING

SIOE OF

BEAM

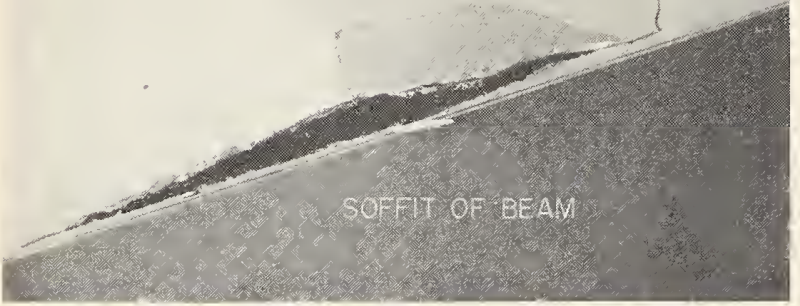

Figure 24. Plaster failure involving an expansion of about 0.5 percent in the white coat along the side of a concrete beam.

making preliminary measurements between $50^{\circ}$ $\mathrm{F}\left(10^{\circ} \mathrm{C}\right)$ and $80^{\circ} \mathrm{F}\left(27^{\circ} \mathrm{C}\right)$, coefficients of thermal expansion of about $12 \times 10^{-6} / \mathrm{deg} \mathrm{F}$ were obtained. The specimens were then raised to $110^{\circ} \mathrm{F}\left(43^{\circ} \mathrm{C}\right)$ in a drying oven and kept at this temperature for 24 hours, after which measurements indicated a coefficient of only about $4 \times 10^{-6} / \mathrm{deg} \mathrm{F}$. This difference was attributed to a moisture effect. Therefore, all the specimens were dried before determining the coefficient of thermal expansion by a method similar to that described by McMurdie and Marsh. The specimens, maintained at low humidities, were measured at five temperatures between $12^{\circ} \mathrm{F}\left(-11^{\circ} \mathrm{C}\right)$ and $110^{\circ} \mathrm{F}\left(43^{\circ} \mathrm{C}\right)$.

The coefficients of thermal expansion of the specimens prepared from the lyydrated dolomitic lime averaged $6.2 \times 10^{-6} / \mathrm{deg} \mathrm{F}$, with a variation of $\pm 0.2 \times 10^{-6} / \mathrm{deg} \mathrm{F}$. The average coefficient for the high-calcium specimens was $6.5 \times 10^{-6} / \mathrm{deg} \mathbf{F}$, with about the same variation.

A sample of finish coat (containing regularly hydrated dolomitic lime) from the wall of a building gave a coefficient of $6.4 \times 10^{-6} / \mathrm{deg} \mathrm{F}$.

The average of three samples of scratch coat composed of 1 part of gypsum plaster to 2 parts of Potomac River sand, by weight, was $8.2 \times 10^{-6} / \mathrm{deg} \mathrm{F}$; for the brown coat $(1: 3)$, the average was $8.1 \times 10^{-6} / \operatorname{deg} \mathrm{F}$.

Specimens prepared from a neat gypsum plaster, sold as bond plaster, gave a coefficient of $9.0 \times 10^{-6} / \mathrm{deg} \mathrm{F}$; checking the values obtained by MeMurdie and Marsh for gaging plaster.

After the dry specimens were measured for thermal expansion, they were maintained at constant temperature, and the relative humidity was increased to 90 percent. Both the highcalcium specimens and the gypsum bond-plaster specimens expanded 0.02 percent, because of the absorption of moisture. These expansions are equivalent to those due to temperature changes of 30 and $22 \mathrm{deg}$ F (16 and $12.2 \mathrm{deg}$ C), respectively. The specimen containing the hydrated dolomitic lime expanded nearly 0.07 percent.
The coefficient of expansion of sanded lime plaster was not determined, because the surveys revealed that in recent years gypsum plasters had almost universally replaced lime plasters in the base coats. It is believed that the coefficient of thermal expansion of sanded lime plaster is about that of lime mortar.

The coefficients of thermal expansion determined at the Bureau, together with some values taken from the literature for clay brick, mortar, brick masonry, concrete, and lime mortar, are given in table 6 .

TABLE 6. Coefficient of thermal expansion of hardened plaster coats and of bases for plaster

\begin{tabular}{|c|c|}
\hline Material & $\begin{array}{l}\text { Coefficient of } \\
\text { thermal expan- } \\
\text { sion (in mil- } \\
\text { lionths per } \\
\text { deg F) }\end{array}$ \\
\hline $\begin{array}{l}\text { Clay brick. } \\
\text { Brick masonry } \\
\text { Lime-sand mortar } \\
\text { Conerete } \\
\text { Mortar } \\
\text { White-coat finish (dolomitic hydrated lime) } \\
\text { White-coat finish (dolomitic hydrated lime, from a wall) } \\
\text { White-coat finish (high-calcium lime) } \\
\text { Gypsum plaster-brown eoat. } \\
\text { Gypsum plaster - seratch coat } \\
\text { Gypsum gaging plaster } \\
\text { Gypsum bond plaster }\end{array}$ & $\begin{array}{l}2.0 \text { to } 4.2 \\
2.5 \text { to } 4.5 \\
4.0 \text { to } 5.0 \\
4.0 \text { to } 6.0 \\
4.5 \text { to } 6.5 \\
6.2 \\
6.4 \\
6.5 \\
8.1 \\
8.2 \\
8.3 \text { to } 9.7 \\
9.0\end{array}$ \\
\hline
\end{tabular}

According to the values in table 6 , there is only a small difference between the coefficients of thermal expansion of the white-coat finishes (dolomitic and high-calcium) and those of the sanded and bond plasters. It is doubtful if there is any marked temperature gradient between the inner face of the base coat and the white coat, which is usually $1 / 16$ to $1 / 8$ inch in thickness. Considering also the relatively small temperature differences in the interior of a building, even with seasonal changes, it is difficult to see how the marked bulges in the white coat can be ascribed to thermal changes. For a temperature rise of $50 \operatorname{deg} \mathrm{F}(27.8 \operatorname{deg} \mathrm{C}$ ), calculations show that the bond plaster, brown coat, and white coat expand $0.025,0.020$, and 0.012 percent, respectively, more than the concrete backing. If the ends were restrained, this would place all of the plaster layers in compression, the bond coat more than either of the others, and any separation, although improbable, would be expected to occur between the concrete and the bond plaster. A'ctually, the maximum relative expansion for a $50 \mathrm{deg} F$ $(27.8 \mathrm{deg} \mathrm{C})$ temperature rise is only one-twentieth of that estimated for the bulge shown in figure 24. Similar relationships occur between the coefficients of thermal expansion of brick masonry and the plaster coats, and here again the plaster would be expected to separate from the backing.

In general, brick and hollow-tile masonry affords an. excellent base for gypsum plaster, and the survey has indicated that plaster failures are primarily in the bond between the dolomitic white-coat finish and the base coat, rather than 
between the base coat and either the masonry or concrete construction.

Finally, the coefficient of thermal expansion of the white coat made with hydrated dolomitic lime is almost identical with that of the finish made with high-calcium lime. Only finishes made with hydrated dolomitic lime containing free $\mathrm{MgO}$ were found to produce bulges.

Therefore, the explanation that differences in thermal cofficients of expansion cause bulges is untenable.

\section{Poor Workmanship}

Three factors must be considered in ascertaining the cause or causes of troubles that develop in a building: (1) the design of the building, (2) the materials used, and (3) the workmanship. Up to this point little has been said about workmanship, but the following comments seem pertinent for those who have been inclined to blame poor workmanship for white-coat-plaster failures.

First, the same workmen, or even different workmen with the same degree of skill, could not possibly have plastered all of the many buildings in which typical white-coat-plaster failures have occurred. As a matter of fact, it was the consensus of opinion of those on the surveys having first-hand acquaintance with the plastering contractors that the plaster work had been done by plastering contractors of excellent reputation, and that in very few cases was there evidence of poor workmanship in the monumental type of buildings inspected. This, of course, does not mean that there is no poor workmanship, especially in some of the speculative buildings.

Second, there has never been a satisfactory explanation advanced that could explain what a skilled workman did, or did not do, in the mechanism of his application of the white coat that could account for the formation of a bulge some 5 to 15 years after he had finished his work.

Third, a survey of buildings, in the area of Washington and Baltimore, plastered by a contractor who used putties prepared in some cases from high-calcium quicklime and in others from regularly hydrated dolomitic finishing lime did not reveal any trouble where the high-calcium lime had been used, but invariably showed failures with dolomitic finishing limes. On many of these jobs the same foreman and identical crews were employed.

\section{Improper Carbonation}

During the course of the surveys, the contention was often made that the plaster failures occurred because the magnesia had not carbonated sufficiently. Although the volume increase resulting from carbonation has already been discussed on the basis of molecular volumes, it may be well to point out once more that carbonation of $\mathrm{Mg}(\mathrm{OH})_{2}$ to $\mathrm{MgCO}_{3} \cdot 3 \mathrm{H}_{2} \mathrm{O}$ (nesquehonite) effects a larger increase than does hydration of $\mathrm{MgO}$ to
$\mathrm{Mg}(\mathrm{OH})_{2}$. Consequently, were it not for the fact that there is little or no evidence that the magnesium is carbonated to $\mathrm{MgCO}_{3} .3 \mathrm{H}_{2} \mathrm{O}$, except in extreme conditions, it would have to be concluded that carbonation actually accelerates the expansion and the formation of bulges. In fact, the carbonation to $\mathrm{MgCO}_{3} \cdot 3 \mathrm{H}_{2} \mathrm{O}$ and the subsequent reaction of this nesquehonite with the gypsum to form $\mathrm{MgSO}_{4} .7 \mathrm{H}_{2} \mathrm{O}$ eventually causes markerl efflorescence and the complete disintegration of the white coat.

\section{Improper Gaging}

Gaging refers to the relative amounts of plaster of paris and lime in the white coat. Individuals encountered on the survey of plaster failures frequently blamed them on improper gaging. In some instances, it was contended that there was too much gaging plaster; in others, too little. For these reasons the probable proportions of lime putty to gaging plaster were determined as described previously. The analyses showed that wide variations seemed to be without measurable effect on the occurrence of failures. Analyses of the many finish coats (table 3 , column 21) showed that failures have occurred where the proportion of lime putty to plaster of paris (by volume) ranged from 0.8 to 9.8 . Nonuniform gaging can therefore be dismissed as a cause for bulges in the white coat.

\section{Painting Plaster Before It Is Sufficiently Dry}

Failures that occur from painting too soon usually show up within a few weeks and are characterized by the formation of small paint blisters containing water. Failures in the white coat take from 5 to 15 or more year's to develop. On some of the Federal buildings where white-coat-plaster failures were observed, the paint had not been applied until $3 \frac{1}{2}$ to 4 years after the plastering had been completed.

\section{Paint Shrinkage}

Paint shrinks as it dries and ages. In any plaster failure caused by paint shrinkage, the paint would be on the concave side of the plaster fragments separating from the base coat. The most extensive white-coat-plaster failures are convex in the direction indicating expansion rather than shrinkage at the painted surface.

\section{Vibration}

The authors are unable to imagine, and no one has suggested, a mechanism whereby vibration of a building could be transmitted from the structural frame in such a way as to form bulges in the rigid, hard, and brittle white-coat plaster. A mechanism that will distinguish between highcalcium and dolomitic limes in the white coat seems particularly difficult to describe. 


\section{Movements in the Structural Frame}

The movements caused by settling, deflection, expansion, etc. in the frame of a building can be transmitted to the wall and ceiling surfaces only through the intervening structures. It is difficult to see how such movements, characterized by cracks, could cause bulges in the white coat, yet most failures were found where there was no evidence of cracks in beams, slabs, walls, or columns.

\section{Preventing Failures of White- Coat Plaster in New Buildings}

In the introduction of this paper it is stated that its purpose is twofold: first, to give the results of the investigation of a particular kind of plaster failure that is characterized by the formation of blisters or bulges in the finish surface of plastcr; and, second, to explain to the architect, engineer, plastering contractor, plasterer, and others concerned with plastering, the precautions that should be exercised in new buildings to prevent such failures.

Up to this point, the paper has been confined largely to the first of these objectives. It should be evident that the white-coat-plaster failures described were caused by slow hydration and expansion of the $\mathrm{MgO}$ in the partially hydrated dolomitic lime used in the preparation of the white coat. In some instances similar failures occurred in a sand-lime-plaster base coat.

When the results of the investigation were first made known, other Government agencies requested assistance of the Bureau in formulating a specification that would exclude partially hydrated limes containing an undesirably high percentage of unliydrated oxides. Accordingly, the following tentative amendment to Federal Specification $\mathrm{SS}-\mathrm{L}-351$ for hydrated lime [22] was prepared: "The total free (unhydrated) calcium oxide $(\mathrm{CaO})$ and magnesium oxide $(\mathrm{MgO})$ in the hydrated product shall not exceed 8 percent by weight (calculated on the 'as received' basis)." A method was given for determining the quantity of unhydrated oxides.

Shortly thereafter certain of the manufacturers of regularly hydrated dolomitic lime started producing more completely hydrated lime. In most instances this was accomplished by using autoclaves to hydrate the lime at elevated temperatures and pressures.

The 8-percent limit of the unhydrated oxides recently has been included in specifications of the American Society for Testing Materials [7 and 8], as well as in those of the American Standards Association [24], for hydrated lime to be used in white-coat plaster.

Nevertheless, a limitation on the percentage of unhydrated oxides has been criticized on the score that the percentage by itself may not be a complete indication of the potential expansion of a hydrated lime. This objection would be obviated by a performance test. Since unsoundness, as has been pointed out in this investigation, does not exhibit itself for several years, a feasible performance test must also be an accelerated one.

Consequently, an investigation was made at the Bureau to study more completely the expansive characteristies of hydrated limes and to obtain data and information that might be used in formulating an accelerated test acceptable for a specification for the soundness of hydrated lime.

Because there is no satisfactory test procedure for ascertaining volume-change characteristics of hydrated lime by itself, it is necessary to gage the lime with some cementitious material having hydraulic properties. Portland cement was selected as the most suitable hydraulic material for gaging hydrated lime in the preparation of test specimens suitable for autoclaving. The linear expansion caused by the autoclaving of cementlime bars thus provided a measure of the expansive properties of the limes from which they were made.

Eighty commercial limes were subjected to the autoclave treatment and to other tests for determining the effect of variables, such as the proportions of cement to lime and the use of different cements in the bars.

From the techniques developed and the data obtained, details of the test procedure have been worked out [21]. It was proposed that hydrated lime be tested in the proportion of 1 cement to 1 lime (by weight); that the cement used have an expansion of between 0.05 and 0.15 percent; that the autoclaving be done at $295 \mathrm{lb} / \mathrm{mm}^{2}$ gage pressure for 1 hour according to a controlled schedule; and, finally, that the expansion obtained after subtracting the percentage of expansion of the neat-cement bar from the total expansion of the cement-lime bar be limited to not more than 1 percent.

Figure 25 shows the relations of the linear expansions of some autoclaved cement-lime bars to the unhydrated oxides contents of the limes used therein. Note the high expansivity of those limes containing a high percentage of unhydrated oxides, especially of the regularly hydrated dolomitic limes - those limes that have caused and are causing such extensive white-coat failures.

Bearing in mind that the test for soundness should differentiate hydrated limes having low potential expansions from all others, and that "Not a single instance has been found where bulging occurred in a white-coat plaster made with high-calcium lime" [30], it would appear logical to limit the percentage of expansion to that shown by the high-calcium limes. 'The highcalcium limes, characterized, in general, by the lowest percentages of unhydrated oxide, gave the lowest percentages of autoclave expansion. Most of the highly hydrated dolomitic limes (known to the trade as autoclaved, pressure-hydrated, etc.) had percentages of unhydrated oxides and expansions comparable with those of the high-calcium limes. Some of the new limes did not meet this 
requirement, but they arc not truly represcntative of this type of lime as now produced. Several of the limes tested were cxperimental products, and the process of manufacture has been so modified that there is now good reason to believe that the percentages of unhydrated oxides and cxpansions of the highly hydrated limes now available are of the same order of magnitude as those of the high-calcium limes.

A limit of 1.0 percent cxpansion should afford adequate protection for the consumer and not work an unduc hardship on the produccr. Furthermore, since an accelerated performance test should be preferable to a limitation of the chemical composition, it is belicved that a limit of 1 percent (net) on the autoclave expansion of bars made in the proportion of 1 cement: 1 lime (by weight) is better than the 8-percent limit on the unhydrated oxides. An autoclave test for soundness, with this limit, is being submitted to the Federal Specification Board for a proposed revision of Federal Specification SS-L-351 for lime; hydrated (for) structural purposes [5].
Until such a soundness test, or modification thereof, is adopted in spceifications, it is recommended that the consumer insist that hydrated lime contain not more than 8 percent of unhydrated oxides (calculated on the reccived basis). A statement to the effect that the contents meet this requircment is generally printed on the bags of this new typc of lime.

A satisfactory lime putty that is completely hydrated can be obtained from quicklime. It is recommended that the directions for slaking as given in Standard specifications for gypsum plastering, issued by the American Standards Association A42.1-1946 [24], be followed. Sec, also, ASTM C5-26 Appendix.

It has been shown in this investigation of whitecoat-plaster failures that methods have been developed for determining the extent of hydration of $\mathrm{MgO}$. These methods can be used even after lime has been mixed with gaging plaster and applied to the wall or ceiling. To date, most of the data presented relate to white coats that have reached such a state of hydration of $\mathrm{MgO}$ that

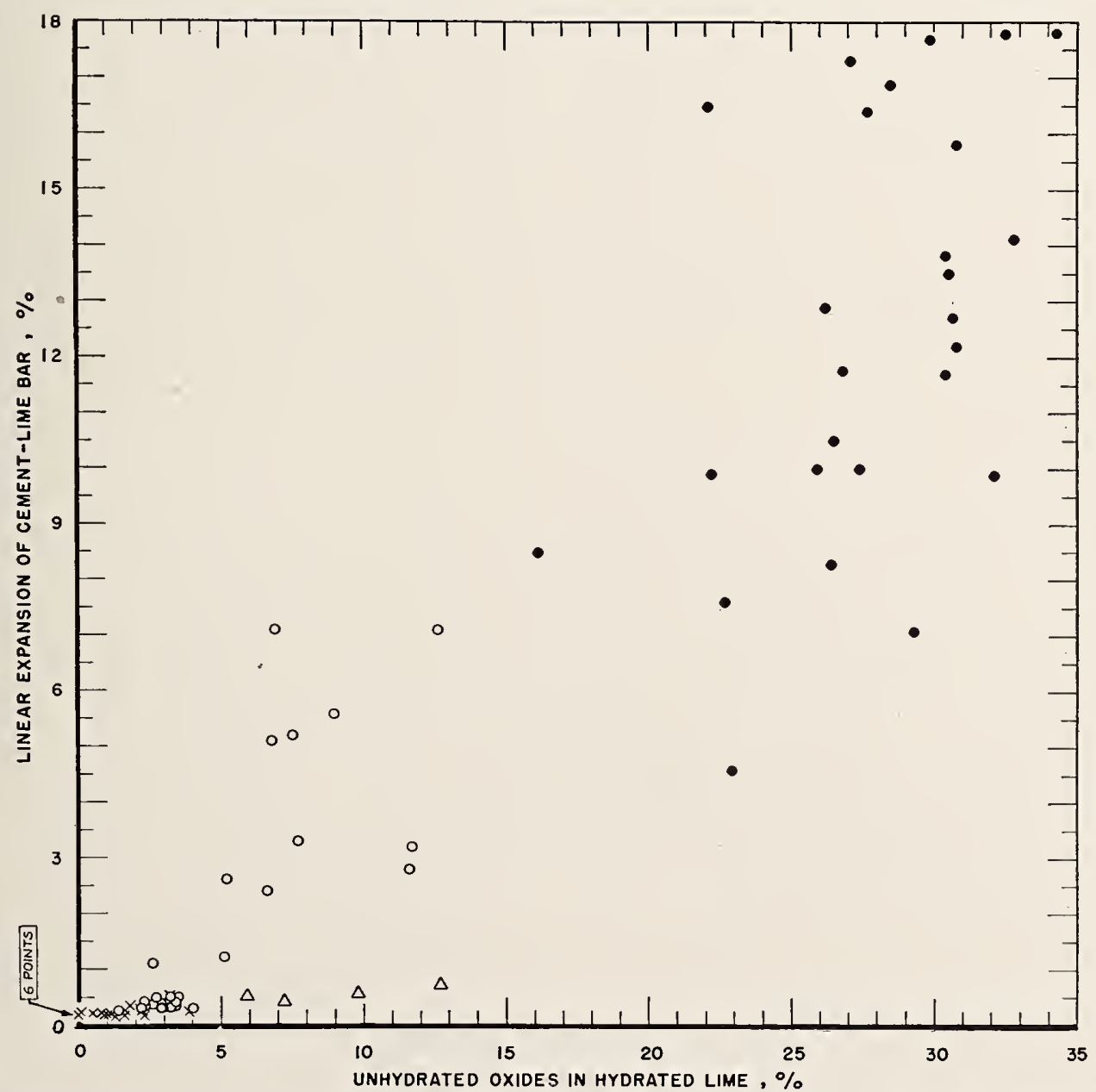

FIGURE 25. Linear expansion of cement-lime bars prepared with hydrated limes containing various amounts of unhydrated oxides, in the proportion of 1 cement to 1 lime (by weight), and subsequently autoclaved for 3 hr at a gage pressure of 295 lb/in ${ }^{2}$. $\mathbf{x}$, High-calcium; $\boldsymbol{\bullet}$, regularly hydrated dolomitic; $\bigcirc$, highly hydrated dolomitic; $\triangle$, magnesian. 
the expansion has resulted in failure. The data in table 3 shows that the average amount of hydration of the $\mathrm{MgO}$ in these plaster-failure samples was 59.0 percent. It is pointed out furthermore that 59.0 percent is much in excess of the average of 19.1-percent hydration found by Wells and Taylor [2] for six nolmally hydrated dolomitic limes after the customary 1 day of soaking as putties. It is also far in excess of the average of 22.6-percent hydration more recently obtained [25] for 18 additional samples of normally (regularly) hydrated dolomitic limes at the end of the customary soaking for 1 day as putties.

No data have been submitted previously in this paper on the extent of hydration of the $\mathrm{MgO}$ in samples taken shortly after the white coat has been applied. Table 7 , however, contains data for six samples of freshly applied white coat - three prepared from regularly hydrated dolomitic limes and three from the new highly hydrated dolomitic limes (autoclaved products).

Samples 1 and 3 pertain to white-coat plasters that were prepared from regularly hydrated limes that had been soaked 1 day before application. Analysis of these plaster samples showed that the extent of hydration of the $\mathrm{MgO}$ was close to 20 percent and, therefore, in agreement with the percentage that should have been hydrated according to values shown by Wells and Taylor [2] and in unpublished dat [25] for lime putties which have been aged for 1 day.
It was known that the regularly hydrated dolomitic lime used in preparing white-coat sample 2 had been soaked 3 days before plastering. According to these previous studies of the extent of hydration of $\mathrm{MgO}$ in putties on aging, about 30 percent of the magnesia should have been hydrated. The analysis of the hardened white coat showed that this is the extent actually found.

Likewise, it was known that highly hydrated dolomitic limes had been used in preparing the white-coat plasters represented by samples 4,5 , and 6 . Consequently, the percentage hydration of the $\mathrm{MgO}$ should be high. Analysis of the set and hardened plaster samples, taken shortly after the white coat had been applied, showed this to be true.

Figure 26 shows the heating curves of the six samples of freshly applied plaster. The samples bear the same numbers in the figure as in table 7 . Note that the heat effect corresponding to the decomposition of $\mathrm{Mg}(\mathrm{OH})_{2}$ is distinctly larger for samples 4,5 , and 6 , those containing highly hydrated dolomitic limes, than for samples 1, 2, and 3 in which regularly hydrated dolomitic limes were used. The reader's attention is invited to the fact that in the heating curves of these freshly applied plasters, the two separate breaks for the decomposition of gypsum and of hemihydrate are less well developed than in the curves for the older failed samples shown in figure 19 .

TABLE 7. Chemical analysis; calculated compound composition; degree of hydration of the magnesia, together with the heats of solution (observed and calculated); percentage of magnesia in the limes; ratio of lime putty to gaging; and extent of carbonation of the $\mathrm{Ca}(\mathrm{OH})_{2}$ in freshly applied white coats

\begin{tabular}{|c|c|c|c|c|c|c|c|c|c|c|c|c|c|c|c|c|c|c|c|c|c|}
\hline \multirow[b]{3}{*}{ 䓌 } & \multicolumn{2}{|c|}{$\begin{array}{l}\text { Loss on ig- } \\
\text { nition at- }\end{array}$} & \multicolumn{6}{|c|}{ Chemical analysis (oxide composition) } & \multirow{3}{*}{ 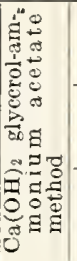 } & \multicolumn{6}{|c|}{ Calculated compound composition } & \multirow{3}{*}{ 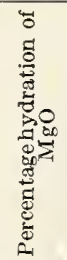 } & \multicolumn{2}{|c|}{$\begin{array}{l}\text { Heat of } \\
\text { solution }\end{array}$} & \multirow{3}{*}{ 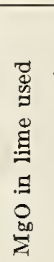 } & \multirow{3}{*}{$\begin{array}{c}\text { Ratio: } \\
\text { lime putty } \\
\begin{array}{c}\mathrm{CaSO}_{4} 1 / 2 \mathrm{H}_{2} \mathrm{O} \\
\text { (hy volume) }\end{array}\end{array}$} & \multirow{3}{*}{ 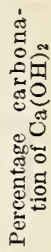 } \\
\hline & & $\begin{array}{l}0 \\
\text { in } \\
\text { s. }\end{array}$ & & & $0^{3}$ & & & & & $\begin{array}{r}\text { Caso } \\
\text { fro }\end{array}$ & $2 \mathrm{H}_{2} \mathrm{O}$ & & & & & & & & & & \\
\hline & $\begin{array}{l}0 \\
: \\
\stackrel{్}{్}\end{array}$ & 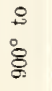 & 0 & $\stackrel{\circ}{\text { શ્I }}$ & 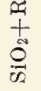 & O̊ & $\begin{array}{l}\stackrel{0}{\infty} \\
= \\
=1\end{array}$ & 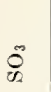 & & 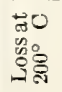 & 0 & 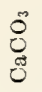 & 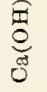 & $\underbrace{\frac{1}{2}}_{\frac{5}{2}}$ & 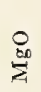 & & $\begin{array}{l}\text { 总 } \\
\text { 总 } \\
\text { 员 } \\
0\end{array}$ & 营 & & & \\
\hline
\end{tabular}

SERLES A. REGULARLY HYDRATED DOLOMITIC LIMES

\begin{tabular}{|c|c|c|c|c|c|c|c|c|c|c|c|c|c|c|c|c|c|c|c|c|c|}
\hline $\begin{array}{l}1 \\
2 \\
3\end{array}$ & $\begin{array}{r}\% \\
9.1 \\
10.0 \\
5.7\end{array}$ & $\begin{array}{c}\% \\
21.1 \\
22.0 \\
23.0\end{array}$ & $\begin{array}{l}\% \\
2.9 \\
3.7 \\
8.1\end{array}$ & $\begin{array}{c}\% \\
18.2 \\
18.3 \\
14.9\end{array}$ & $\begin{array}{l}\% \\
0.7 \\
.8 \\
.5\end{array}$ & $\begin{array}{c}\% \\
39.9 \\
38.9 \\
41.0\end{array}$ & $\begin{array}{l}\% \\
17.1 \\
15.7 \\
22.5\end{array}$ & $\begin{array}{c}\% \\
21.2 \\
23.2 \\
13.3\end{array}$ & $\begin{array}{c}\% \\
24.8 \\
19.1 \\
23.0\end{array}$ & $\begin{array}{l}\% \\
43.5 \\
47.8 \\
27.2\end{array}$ & $\begin{array}{c}\% \\
45.6 \\
49.9 \\
28.6\end{array}$ & $\begin{array}{r}\% \\
6.6 \\
8.4 \\
18.4\end{array}$ & $\begin{array}{c}\% \\
28.2 \\
23.7 \\
28.2\end{array}$ & $\begin{array}{l}\% \\
5.8 \\
6.8 \\
6.7\end{array}$ & $\begin{array}{r}\% \\
13.1 \\
11.0 \\
17.9\end{array}$ & $\begin{array}{l}\text { 口 } 23.6 \\
\text { в } 29.9 \\
\therefore \quad 20.4\end{array}$ & $\begin{array}{r}\text { cally } \\
258 \\
215 \\
304 \\
\end{array}$ & $\begin{array}{r}c a l / g \\
251 \\
218 \\
311\end{array}$ & $\begin{array}{c}\% \\
40.6 \\
40.8 \\
41.5\end{array}$ & $\begin{array}{l}2.0 \\
1.6 \\
4.0\end{array}$ & $\begin{array}{l}15 \\
21 \\
33\end{array}$ \\
\hline
\end{tabular}

SERIES B. HIGHLY HYDRATED DOLOMITIC LIMES

\begin{tabular}{|c|c|c|c|c|c|c|c|c|c|c|c|c|c|c|c|c|c|c|c|c|c|}
\hline $\begin{array}{l}4 \\
5 \\
6\end{array}$ & $\begin{array}{l}6.1 \\
7.7 \\
7.2\end{array}$ & $\begin{array}{l}25.7 \\
31.6 \\
27.1\end{array}$ & $\begin{array}{r}3.1 \\
15.4 \\
5.5\end{array}$ & $\begin{array}{l}22.6 \\
16.2 \\
21.6\end{array}$ & $\begin{array}{r}1.4 \\
.7 \\
.5\end{array}$ & $\begin{array}{l}39.0 \\
35.0 \\
37.9\end{array}$ & $\begin{array}{l}20.5 \\
16.0 \\
18.6\end{array}$ & $\begin{array}{l}13.5 \\
16.8 \\
15.8\end{array}$ & $\begin{array}{r}32.7 \\
2.2 \\
22.6\end{array}$ & $\begin{array}{l}29.1 \\
36.8 \\
34.4\end{array}$ & $\begin{array}{l}29.0 \\
36.1 \\
34.0\end{array}$ & $\begin{array}{r}7.1 \\
35.0 \\
12.5\end{array}$ & $\begin{array}{r}33.8 \\
4.8 \\
26.2\end{array}$ & $\begin{array}{l}26.9 \\
23.2 \\
26.3\end{array}$ & $\begin{array}{r}1.9 \\
-0.0 \\
.4\end{array}$ & $\begin{array}{r}\text { A.0 } 90.6 \\
\text { a } 100.0 \\
\text { \& } 97.8\end{array}$ & $\begin{array}{l}283 \\
141 \\
238\end{array}$ & $\begin{array}{l}278 \\
136 \\
231\end{array}$ & $\begin{array}{l}41.0 \\
40.8 \\
40.9\end{array}$ & $\begin{array}{l}3.6 \\
2.3 \\
2.8\end{array}$ & $\begin{array}{r}13 \\
\text { d } 85 \\
26\end{array}$ \\
\hline
\end{tabular}

- Hydrated lime soaked 1 day as putty before being used.

b Hydrated lime soaked 3 days as putty hefore being used. - Hydration of $\mathrm{MgO}$ to 90.6 percent corresponds to 96.2 -percent hydration
for the lime.

It should be apparent from these studies that it is now possible to determine from an analysis of the hardened white coat whether a regularly hydrated or a highly hydrated dolomitic lime was used on the job. d Sanded gypsum hase coat applied over bituminous coating on outside wall, with result that the plaster remained damp for some time and conse: quently was rather weak. Dampness also prohahly accounts for high percentage of carhonation of $\mathrm{Ca}(\mathbf{O H})_{2}$. Sample taken 6 weeks after plastering. - Contains in addition 0.3 percent of excess $\mathrm{H}_{2} \mathrm{O}$,

It has often been suggested that after slight additional aging beyond the customary 1-day soaking, regularly hydrated dolomitic lime would perhaps be satisfactory for the white coat. Although the data of Wells and Taylor [2] indicated 


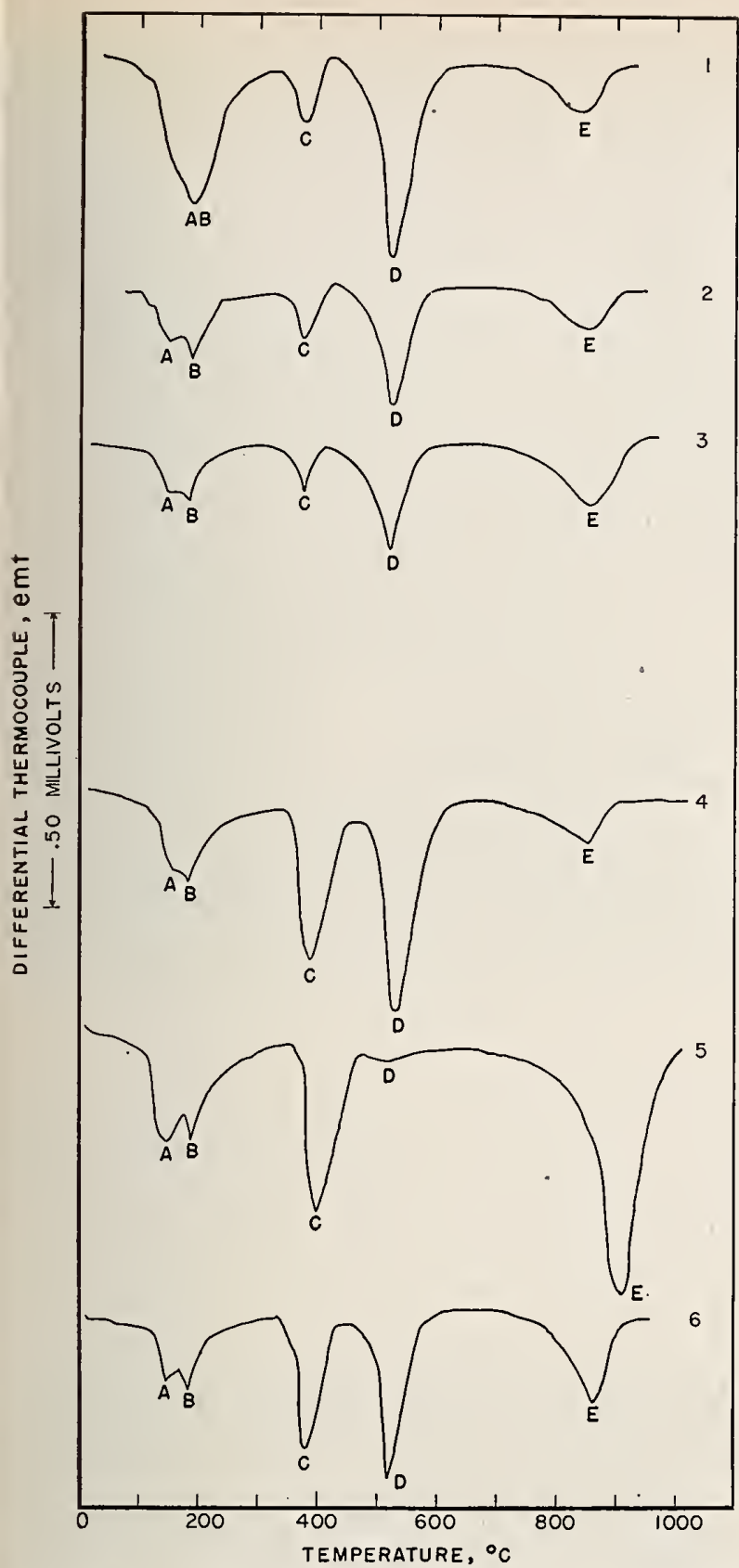

Figure 26. Differential heating curves of six freshly applied white coats.

The chemical analyses are given in table 7. The five major regions of heat absorption in the order of increasing temperature are A, dehydration of gypsum, B, dehydration of hemihydrate, C, dehydration of magnesium hydroxide, $\mathrm{D}$, dehydration of calcium hydroxide, and $\mathrm{E}$, decomposition of calcium carbonate.

that several months might be required to hydrate the $\mathrm{MgO}$ completely, nevertheless, the data pertained to but six limes, and there is the possibility that recent technical advances in the lime industry may have since produced more reactive hydrates. Consequently, an investigation, previously mentioned, was undertaken at the Bureau to study the rate of hydration of the present-day regularly hydrated dolomitic limes and to ascertain the time required to age such limes as putties so that the percentages of expansion of coment-lime bars would be reduced to 1 pereent or less [25].

Eighteen representative limes of the regularly hydrated dolomitic type were chosen for that study. A few of the findings of that investigation have been mentioned in this paper. A complete report of that work is being prepared for publication. Nevertheless, for the bearing which those findings have on this problem of preventing whitecoat-plaster failures in the future, some of the salient factors should be presented at this time.

As has already been pointed out, roughly but 20 , 30 , and 40 percent of the $\mathrm{MgO}$ in the regularly hydrated dolomitic finishing limes is hydrated at the end of soaking periods of 1,3 , and 7 days, respectively. The average expansions of the cement-lime bars were $11.0,10.6$, and 9.7 percent, respectively, at these time periods. The shortest time required for aging the putties in order to reduce the expansion to 1 percent was 3 weeks, and for three of the limes the expansion exceeded 1 percent, even after 32 weeks of soaking. It should be evident, therefore, that it would be most difficult to specify the time of aging required to hydrate satisfactorily the magnesia in the ordinary dolomitic finishing lime. To include all of the slower hydrating products would require a soaking period of at least 7 to 8 months. But whether the period was 3 weeks or 7 to 8 months, the time would be altogether too long from a practical standpoint.

\section{Methods of Repairing Damaged Plaster}

The cause of white-coat-plaster failures and the precautions that should be exercised in the erection of new buildings to prevent such failures have been discussed. Two questions have often been presented to the Bureau: (1) Is there any known method of stopping or minimizing destructive expansion if a defective lime has been used in preparing the white coat? and (2) what are the best methods of repairing the damage? The answers to these questions are still matters of conjecture.

Frank Murphy, of the Krafft-Murphy Co. (plastering contractors of Washington, D. C.) has conducted some limited experiments on potentially defective areas by applying thereon two or more coats of aluminum paint made with a spar-varnish vehicle. Such a coating may act as a sufficiently effective vapor barrier to prevent the condensation of much moisture within the plaster during periods of high temperature and high relative humidity. To date, his experiments seem encouraging, but several seasons must elapse before the effectiveness of this method can be evaluated. More extensive experiments are needed.

It is often difficult to decide upon the best procedure to follow when faced with the problem of repairing defective white coat. Usually the owner 


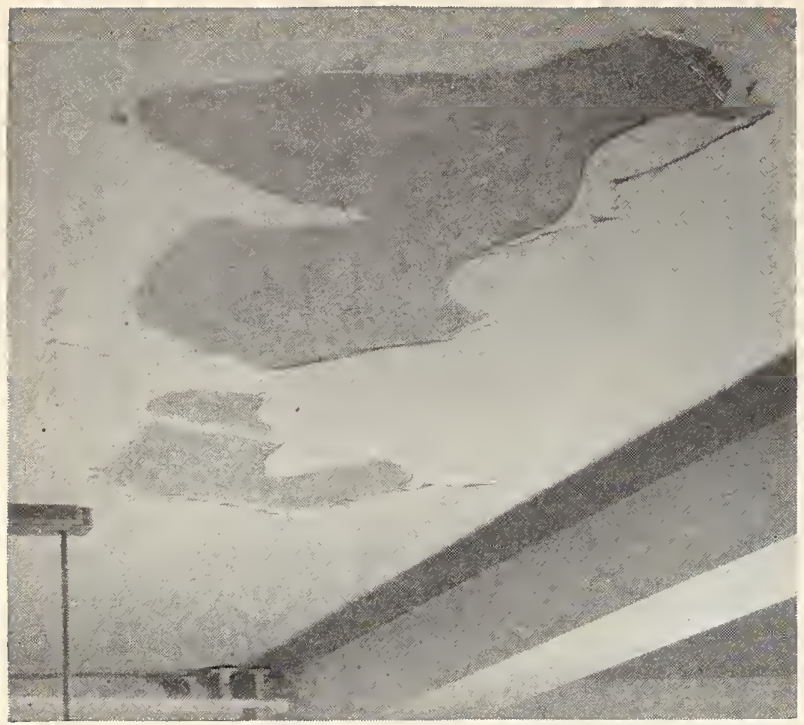

Figure 27. A ceiling in an office building where whitecoat plaster failures are of frequent occurrence and where repatching has been going on for years.

The loose white coat has been sealed off, revealing the sound condition of the sanded base coat.

or building manager employs a plasterer to scale off the loose white-coat plaster and patch the damaged places. This plastering operation necessitates redecorating the wall or ceiling involved, thus adding to the cost of the repair. Almost invariably the owner will discover that while the fresh patch may stay on, other old areas of white coat will break loose, until in many cases there will be numerous patches in the same ceiling or side wall. Each of the plaster repairs will entail redecorating, with resultant additional cost.

Figure 27 shows a ceiling in an office building wher: white-coat-plaster failures are of frequent occurrence and where repatching has been going on for years. The bulged and loose white coat has been scaled off. Note the sound condition of the sanded base coat. The patches in this building have now become so extensive that they cover from one-half to two-thirds of the area of the plastered surfaces. The old patches are now showing signs of failure characterized by the typical bulges and loosening of the white coat.

Unsound regularly hydrated dolomitic lime, with its high percentage of unhydrated $\mathrm{MgO}$, was used in the original white coat and all subsequent patching. After spending thousands of dollars, the owners have little to show for their efforts. 'The walls and ceilings are a network of patches, and the entire surface is still potentially unsound.

Figure 28 shows a plastered ceiling with an extensive area that had been patched because of the loosening of the white coat. But, more important, it shows additional white-coat-plaster failures that occurred subsequent to the patching but before the painter got around to redecorating the ceiling. Faced with the continuous reappearance of bulged and defective areas, it was finally decided that the

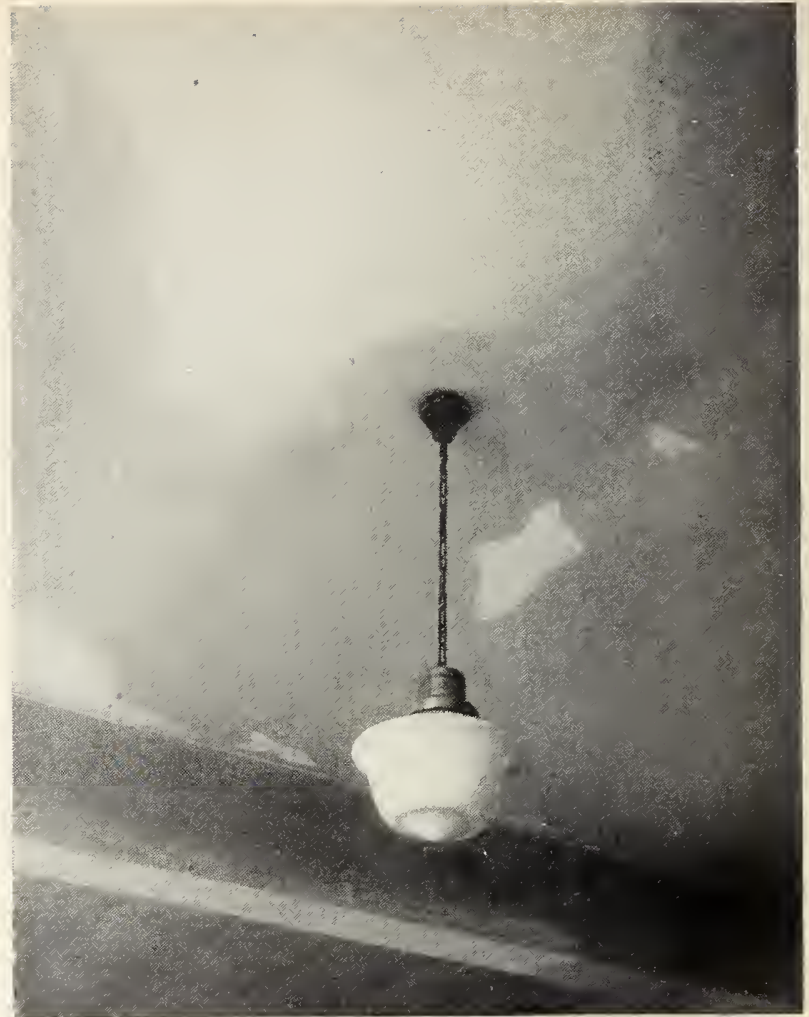

Figure 28. An extensive area of patched white coat and additional areas of delaminated white coat that occurred subsequent to patching.

best policy in this parochial school would be to cover the ceilings with some material that would not undergo excessive expansion with seasonal changes. Hence, the selection of pressed metal as a ceiling material. Note in figure 29, however, that bulges are still appearing in the white coat on the concrete beams.

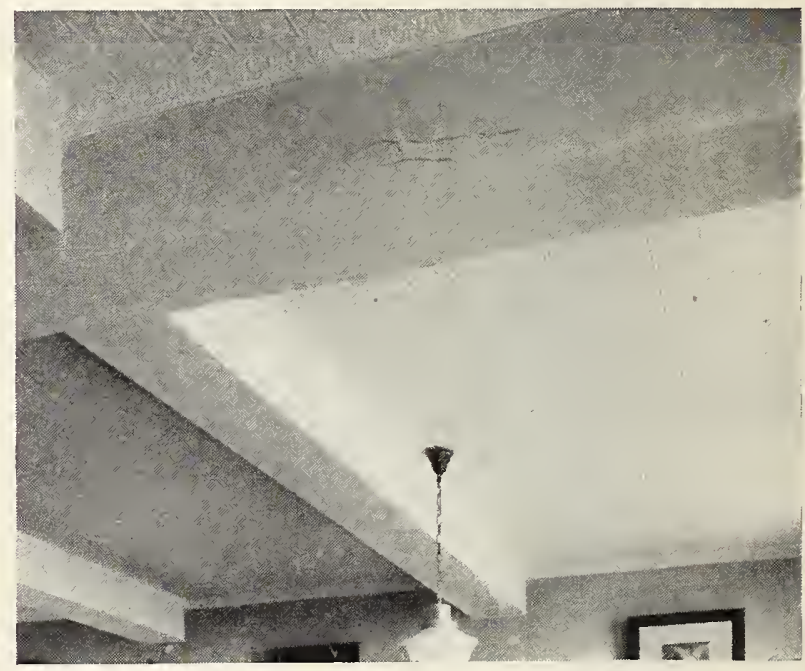

FIGURE 29. Faced with the condition illustrated in figure 28 , the ceilings in this parochial school are being replaced with pressed metal.

Note that plaster failures are still occurring on the concrete beams. 
It should bc obvious, therefore, that owners and building managers are continuously faced with the problem of whether it is more economical to patch and repatch or to remove the entire white coat. It should be equally obvious that the probability of future trouble is not eliminated if the regularly hydrated type of dolomitic lime, with its high percentage of free $\mathrm{MgO}$, is used in making the repairs.

Another problem is the selection of the best method of removing the white coat without unduly damaging the base coat. Some plasterers prefer to heat the white coat with a blow torch; others find it easier to saturate the white coat with a fine spray of water. 'The water hastens the hydration of $\mathrm{MgO}$ and brings about an expansion that loosens the white coat from the underlying base coat. In either casc it is necessary to chop off certain areas with hatchets.

Only lime putty prepared from a highly hydrated finishing lime or a completely slaked quicklime should be used for the new white coat.

In many instances it has been found to be more advantageous and economical not to attempt to remove the defective white coat but rather to cover the ceilings with wall board or acoustic tile. As it would be unwise to attach these materials directly to unsound white coat, it is necessary to nail furring strips to the plaster backing and then to attach the new covering to these strips.

\section{Summary and Conclusions}

As a result of this survey and investigation of white-coat-plaster failures, the following statements and conclusions are justified:

1. Extensive surveys showed that plaster failures characterized by the formation of bulges (large blisters) in the white coat with its delamination are widespread where ordinary hydrated dolomitic finishing lime has been used in preparing the white coat.

2. Several years (from about 5 to 15 , but usually 8 to 9 ) elapse before the blisters, or bulges, appear, and thereafter the number and extent of failures increase as the age of the buildings increases.

3. The failures occur more extensively and rapidly during the warm weather of summer and during periods of high relative humidity.

4. There is a marked similarity in the failures, regardless of the kind of plaster base coats, construction bases, job conditions, and type of workmanship.

5. The usual white coat is prepared from a lime putty gaged with plaster of paris (gypsum gaging plaster). Lime putty is prepared on the job either by slaking quicklime with an excess of water, or by soaking a dry commercial finishing hydrated lime with water. The tendency is very strongly in favor of the hydrate because of its greater convenience.

6 . Nearly all finishing hydrated limes are made from a dolomitic limestone peculiar to a small district in northwestern Ohio, because such hydrated limes yield plastic putties desired by the plasterer.

7. In the lime-burning of dolomite $\left(\mathrm{MgCO}_{3}\right.$. $\mathrm{CaCO}_{3}$ ), the magnesium carbonate is decomposed into $\mathrm{MgO}+\mathrm{CO}_{2}$ long before the calcium carbonate is completely decomposed. 'Thus the $\mathrm{MgO}$ becomes overburned and its reactivity toward water is greatly reduced.

8 . Only 55 to 65 percent of the water required for complete hydration of regularly hydrated dolomitic finishing lime is present, because of the slowness of hydration of the badly overburned $\mathrm{MgO}$ in the normal hydration process.

9. The calcium oxide of hydrated dolomitic limes is generally completely hydrated, but only a relatively small percentage of the magnesia is hydrated.

10. The 12- to 24-hour soaking hydrates but little of the large percentage of unhydrated $\mathrm{MgO}$; thus, about 75 to 80 percent remains unhydrated when the white coat is applied.

11. The presence of $\mathrm{CaSO}_{4} \cdot 2 \mathrm{H}_{2} \mathrm{O}, \mathrm{Mg}(\mathrm{OH})_{2}$, $\mathrm{Ca}(\mathrm{OH})_{2}$, and $\mathrm{CaCO}_{3}$ in the white coat was confirmed by differential thermal analysis.

12. The observed heats of solution of the whitecoat plaster's agree closely with those calculated from the computed compound composition. This agreement is strong evidence of the correctness of the assumptions upon which are based the calculations of the constitution of the plasters.

13. The average amount of hydration of the $\mathrm{MgO}$ for 88 samples of failed white coat was 59 perccnt. This is much in excess of the average 20 percent found after the customary 1 day of soaking of the lime as a putty. Hydration of magnesia must, therefore, have occurred on the wall.

14. In every instance of failure, a dolomitic lime had been used in preparing the white coat. 'That is, in not a single instance had a highcalcium lime been used.

15. Plaster failures from which the 88 samples were taken occurred with volume ratios of lime putty to calcined gypsum (gaging plaster) as low as 0.8 and as high as 9.8. The average ratio was 3.9

16. The cxtent of carbonation of the lime in the white coat at the time of failure ranged from 9 to 100 percent, and the mean was 60 percent.

17. Samples of white coat expanded markedly on steaming in an autoclave for one hour at a pressure of $120 \mathrm{lb} / \mathrm{in}^{2}{ }^{2}$ when the $\mathrm{MgO}$ was converted to $\mathrm{Mg}(\mathrm{OH})_{2}$, with the attending increase in volume.

18. Although the investigation was confined primarily - to white-coat plaster, nevertheless, failures were also observed in basc coats in which dolomitic lime containing considerable unhydrated $\mathrm{MgO}$ was used.

19. Proposed explanations of the cause of failure of white-coat plaster, other than hydration of magnesia, were given consideration. They 
included the drying shrinkage of concrete, differences in thermal expansion between the backing and the various coats of plaster, poor workmanship, improper carbonation, improper gaging, painting plaster before it is sufficiently dry, paint shrinkage, vibration, and movements in the structural frame. It was shown that these factors are inadequate to account for the bulges in the plaster that occur several years after a building has been erected.

20. It was concluded that the one factor offering a reasonable explanation for the failures is the gradual expansion attending the hydration of free $\mathrm{MgO}$ in the set and hardened white coat.

21. The precautions that should be exercised in specifying the proper lime in order to prevent failures in new buildings are discussed.

22. Some of the methods that have been used in repairing damaged plaster are discussed.

The authors express thanks and appreciation to E. P. Flint for analyzing many of the samples of failed white coat, to H. F. McMurdie for obtaining X-ray diffraction patterns of the samples, and to S. W. Benedict and J. M. Cameron for their statistical analysis of the correlation between the observed and calculated heats of solution of the 88 samples of failed white-coat plaster. The authors are indebted to Frank Murphy for his great interest in this investigation and for the many hours of his time that he so willingly gave in the surveys in Washington, D. C., and Baltimore, $\mathrm{Md}$.

\section{References}

[1] E. D. Raht, Remedy for falling plaster, from section "Letters to the Editor", Building and Building Management 39, No. 11, p. 44 (October 1939).

[2] Lansing S. Wells and Kenneth Taylor, Hydration of magnesia in dolomitic hydrated limes and putties, J. Research NBS 19, 215 (1937) RP1022.

[3] Federal Specification SS-Q-351 for quicklime; (for) structural purposes (1930).

[4] Standard specifications for quicklime for structural purposes. ASTM Designation: C5-26, ASTM Standards, part II, 90 (1946).

[5] Federal Specification SS-L-35i for lime; hydrated (for) structural purposes (1930).

[6] Tentative specifications for normal finishing hydrated lime. ASTM Designation: C6-46T, ASTM Standards, part II, 1304 (1946).

[7] Tentative specifications for special finishing hydrated lime. ASTM Designation: C206-46T, ASTM Standards, part II, 1306 (1946).

[8] Tentative specifications for hydrated lime for masonry purposes. ASTM Designation: C207-46T, ASTM Standards, part II, 1308 (1946).

[9] K. K. Kelley and C. T. Anderson, Contributions to the data on theoretical metallurgy, IV. Metal carbonates-Correlations and applications of thermodynamic properties, U. S. Bureau of Mines Bul. 384 (1936).
[10] J. Johnston, The thermal dissociation of calcium carbonate, J. Am: Chem. Soc, 32, 938 (1910).

[11] F. H. Smyth and L. H. Adams, The system, calcium oxide-carbon dioxide, J. Am. Chem. Soc. 45, 1167 (1923).

[12] W. Dutoit, Tensions de dissociation des carbonates de calcium, de strontium et de barium, J. chim. phys. 24, $110(1927)$.

[13] L. Andrussow, Über die thermische Dissoziation des Calciumkarbonats und die Differentialmethode, Z. phy. Chem. 116, 81 (1925)

[14] Karl v. Kohner, Ueber die Dissoziationsspannung des Calciumcarbonates, Inaugural-Dissertation, Friedrich-Wilhelms-Universität zu Berlin, 1914.

[15] S. Tamaru, K. Siomi, and M. Adati, Neubestimmung thermischer Dissoziationsgleichgewichte von anorganischen Verbindungen. I., Z. phys. Chem. A-15\%, 447 (1931)

[16] O. C. Ralston, R. D. Pike, and L. H. Duschak, Plastic magnesia, U. S. Bureau of Mines Bul. 236 (1925).

[17] Sidney Speil, Louis H. Berkelhamer, Joseph A. Pask, and Ben Davies, Differential thermal analysis. Its application to clays and other aluminous minerals, U.S. Bureau of Mines Tech. Paper 664 (1945)

[18] Edward DeMille Campbell, On the influence of the temperature of burning on the rate of hydration of magnesium oxide, Ind. Eng. Chem. 1, 665 (1909); 10, 595 (1918).

[19] D. F. Richardson, Analysis of hydrated lime by a thermochemical method, Ind. Eng. Chem. 19, 625 (1927).

[20] E. L. Fox and F. C. Mathers, Determination of the degree of hydration of magnesia in dolomitic limes, Proc. Indiana Acad. Sci. 43, 113 (1934).

[21] Lansing S. Wells, Walter F. Clarke, and Ernest M. Levin, Expansive characteristies of hydrated limes and the development of an autoclave test for soundness, J. Research NBS 41, 179 (1948) RP1917.

[22] Proposed amendment to Federal Specification SS-I351 for lime; hydrated (for) structural purposes. Date of amendment, Feb. 2, 1940.

[23] Tentative revision of standard methods of chemical analysis of limestone, quicklime, and hydrated lime. ASTM Designation: C25-44, submitted June 1945; see ASTM Standards, part II, 1701 (1946).

[24] Standard specifications for gypsum plastering; including requirements for lathing and furring. Am. Standards Assn. A42.1-1946.

[25] Unpublished data.

[26] Dana L. Bishop, Function of carbon dioxide in producing efflorescence on plaster and cement products, J. Research NBS 30, 361 (1943) RP1538.

[27] Federal Specification SS-P-402 for plaster; gypsum (1945).

[28] Standard methods of testing gypsum and gypsum products. ASTM Designation: C26-42, ASTM Standards, part II, 149 (1946)

[29] William Lerch and R. H. Bogue, Revised procedure for the determination of uncombined lime in portland cement, Ind. Eng. Chem., analytical edition, 2, 296 (1930)

[30] E. S. Newman, Investigation of plaster failure, Am. Ceramic Soc. Bul. 26, No. 4, 117-118 (1947).

[31] Edwin S. Newman and Lansing S. Wells, Heats of hydration and transition of calcium sulfate, J. Research NBS 20, 825 (1938) RP1107.

[32] H. F. McMurdie and F. L. Marsh, Volume changes of gypsum fiber concrete, Rock Products 35, 20 (March 26, 1932).

Washington, June 19, 1950. 




\title{
BUILDING MATERIALS AND STRUCTURES REPORTS
}

\author{
[Continued from cover page II]
}

BMS32 Structural Properties of Two Brick-Concrete-Block Wall Constructions and a Concrete-Block Wall Construction Sponsored by the National Concrete Masonry

BMS33

BMS34

BMS35

BMS36

BMS37

BMS38

BMS39

BMS40

BMS41

BMS42

BMS43

BMS44

BMS45

BMS46

BMS47

BMS48

BMS49

BMS50

BMS51

BMS52

BMS53

BMS54

BMS55

BMS56

BMS57

BMS58

BMS59

BMS60

BMS61

BMS62

BMS63

BMS64

BMS65

BMS66

BMS67

BMS68

BMS69

BMS70

BMS71

BMS72

BMS73

BMS74

BMS75

BMS76

BMS77

BMS78

BMS79

BMS80

BMS81

- Out of print. Association .........

Stability of Sheathing Papers as Determined by Accelerated Aging

Structural Properties of Wood-Frame Wall, Partition, Floor, and Roof Constructions With "Red Stripe" Lath Sponsored by The Weston Paper and Manufacturing $\mathrm{Co}$

Structural Properties of "Palisade Homes" Constructions for Walls, Partitions, and Floors, Sponsored by Palisade Homes

Structural Properties of Two "Dunstone" Wall Constructions Sponsored by the W. E. Dunn Manufacturing Co

Structural Properties of a Wall Construction of "Pfeifer Units" Sponsored by the Wisconsin Units Co

Structural Properties of a Wall Construction of "Knap Concrete Wall Units" Sponsored by Knap America, Inc.

Effect of Heating and Cooling on the Permeability of Masonry Walls
Structural Properties of Wood-Frame Wall and Partition Construction with "Celotex" Insulating Boards Sponsored by The Celotex Corporation.

Performance Test of Floor Coverings for Use in Low-Cost Housing: Part 2

Surface Treatment of Steel Prior to Painting

Air Infiltration Through Windows Structural Properties of "Scott-Bilt" Prefabricated Sheet-Steel Constructions for Walls, Floors, and Roofs Sponsored by The Globe-Wernicke Co._. Structural Properties of Prefabricated Wood-Frame Constructions for Walls, Parti-

ons and Floors Sponsored by American Houses, Inc
Structural Properties of "Precision-Built" Frame Wall and Partition Constructions Sponsored by the Homasote Co

Metallic Roofing for Low-Cost House Construction

Stability of Fiber Building Boards as Determined by Accelerated Aging

Structural Properties of "Tilecrete Type A" Floor Construction Sponsored by the Tilecrete Co ........

Effect of Ceiling Insulation Upon Summer Comfort

Structural Properties of a Masonry Wall Construction of "Munlock Dry Wall Brick" Sponsored by the Munlock Engineering Co

Effect of Soot on the Rating of an Oil-Fired Heating Boiler

Effects of Wetting and Drying on the Permeability of Masonry Walls A Survey of Humidities in Residences.

Roofing in the United States-Results of a Questionnaire

Strength of Soft-Soldered Joints in Copper Tubing.

Properties of Adhesives for Floor Coverings Bricks Produced in the United States

Structural Properties of Two Nonreinforced Monolithic Concrete Wall Constructions $-1_{10}$ Structural Properties of a Precast Joist Concrete Floor Construction Sponsored by the Portland Cement Association.

Moisture Condensation in Building Walls

Solar Heating of Various Surfaces

Methods of Estimating Loads in Plumbing Systems

Plumbing Manual.-Walls, Partitions, Floors, and Roofs, Sponsored by Herman A. Mugler. Performance Test for Floor Coverings for Use in Low-Cost Housing: Part 3 Stability of Fiber Sheathing Boards as Determined by Accelerated Aging Asphalt-Prepared Roll Roofings and Shingles Fire Tests of Wood-and Metal-Framed Partitions Construction Sponsored by the Homasote Co

Indentation Characteristics of Floor Coverings

Structural and Heat-Transfer Properties of "U. S. S. Panelbilt" Prefabricated SheetSteel Constructions for Walls, Partitions, and Roofs Sponsored by the Tennessee Coal, Iron \& Railroad Co

Effect of Outdoor Exposure on the Water Permeability of Masonry Walls

Properties and Performance of Fiber Tile Boards _.

Structural, Heat-Transfer, and Water-Permeability Properties of Five Earth-Wall Constructions

Water-Distributing Systems for Buildings.

Performance Test of Floor Coverings for Use in Low-Cost Housing: Part 4

Field Inspectors' Check List for Building Constructions (cloth cover, 5 x $71 / 2$ inches)

[List continued on cover page Iv] 


\section{BUILDING MATERIALS AND STRUCTURES REPORTS}

\section{[Continued from cover page III]}

BMS82

BMS83

BMS84

BMS85

BMS86

BMS87

BMS88

BMS89

BMS90

BMS91

BMS92

BMS93

BMS94

BMS95

BMS96

BMS97

BMS98

BMS99

BMS100

BMS101

BMS102

BMS103

BMS104

BMS105

BMS106

BMS107

BMS108

BMS109

BMS110

BMS111

BMS112

BMS113

BMS114

BMS115

BMS116

BMS117

BMS118

BMS119

BMS120

BMS121

Water Permeability of Walls Built of Masonry Units

Strength of Sleeve Joints in Copper Tubing Made With Various Lead-Base Solders

Survey of Roofing Materials in the South Central States.

Dimensional Changes of Floor Coverings With Changes in Relative Humidity and Temperature

Structural, Heat-Transfer, and Water-Permeability Properties of "Speedbrik" Wall Construction Sponsored by the General Shale Products Corporation ...........

A Method for Developing Specifications for Building Construction-Report of Subcommittee on Specifications of the Central Housing Committee on Research, Design, and Construction
Recommended Building Code Requirements for New Dwelling Construction With Special Reference to War Housing

Structural Properties of "Precision-Built, Jr." (Second Construction) Prefabricated Wood-Frame Wall Construction Sponsored by the Homasote Co _. . _ _ . . . . . 15 Structural Properties of "PHC" Prefabricated Wood-Frame Constructions for Walls, Floors, and Roofs Sponsored by the PHC Housing Corporation. A Glossary of Housing Terms Fire-Resistance Classifications of Building Constructions Accumulation of Moisture in Walls of Frame Construction During Winter Exposure -.Water Permeability and Weathering Resistance of Stucco-Faced, Gunite-Faced, and "Knap Concrete-Unit" Walls.

Tests of Cement-Water Paints and Other Waterproofings for Unit-Masonry Walls.-Properties of a Porous Concrete of Cement and Uniform-Sized GravelExperimental Dry-Wall Construction With Fiber Insulating Board Physical Properties of Terrazzo Aggregates "Multiple Box-Girder Plywood Panels" for Walls, Floors, and Roofs

Relative Slipperiness of Floor and Deck Surfaces Strength and Resistance to Corrosion of Ties for Cavity Walls Painting Steel.

Measurements of Heat Losses From Slab Floors.

Structural Properties of Prefabricated Plywood Lightweight Constructions for Walls, Partitions, Floors, and Roofs Sponsored by the Douglas Fir Plywood Association.-- 30

Paint Manual with particular reference to Federal Specifications _..... Laboratory Observations of Condensation in Wall Specimens .

Building Code Requirements for New Dwelling Construction Temperature Distribution in a Test Bungalow With Various Heating Devices Strength of Houses: Application of Engineering Principles to Structural Design Paints for Exterior Masonry Walls _ _ Performance of a Coal-Fired Boiler Converted to Oil Properties of Some Lightweight-Aggregate Concretes With and Without an Airentraining Admixture ... Fire Resistance of Structural Clay Tile Partitions Temperature in a Test Bungalow With Some Radiant and Jacketed Space Heaters.-. 256 A Study of a Baseboard Convector Heating System in a Test Bungalow Preparation and Revision of Building Codes Fire Resistance of Walls of Lightweight Aggregate Concrete Masonry Units.... $20 \phi$ Stack Venting of Plumbing Fixtures Wet Venting of Plumbing Fixtures Fire Resistance of Walls of Gravel-Aggregate Concrete Masonry Units. Investigation of Failures of White-Coat Plasters

-Out of print. 